This document was prepared in conjunction with work accomplished under Contract No. DE-AC09-96SR18500 with the U. S. Department of Energy.

\title{
DISCLAIMER
}

This report was prepared as an account of work sponsored by an agency of the United States Government. Neither the United States Government nor any agency thereof, nor any of their employees, makes any warranty, express or implied, or assumes any legal liability or responsibility for the accuracy, completeness, or usefulness of any information, apparatus, product or process disclosed, or represents that its use would not infringe privately owned rights. Reference herein to any specific commercial product, process or service by trade name, trademark, manufacturer, or otherwise does not necessarily constitute or imply its endorsement, recommendation, or favoring by the United States Government or any agency thereof. The views and opinions of authors expressed herein do not necessarily state or reflect those of the United States Government or any agency thereof.

This report has been reproduced directly from the best available copy.

Available for sale to the public, in paper, from: U.S. Department of Commerce, National Technical Information Service, 5285 Port Royal Road, Springfield, VA 22161, phone: (800) 553-6847, fax: (703) 605-6900

email: orders@ntis.fedworld.gov

online ordering: http://www.ntis.gov/help/index.asp

Available electronically at http://www.osti.gov/bridge

Available for a processing fee to U.S. Department of Energy and its contractors, in paper, from: U.S. Department of Energy, Office of Scientific and Technical Information, P.O. Box 62, Oak Ridge, TN 37831-0062,

phone: (865)576-8401,

fax: (865)576-5728

email: $\underline{\text { reports@ adonis.osti.gov }}$ 
Key Words:

Rheology, Physical Properties

\title{
Retention: Permanent
}

Key WTP R\&T References:

Test Specification:

24590-LAW-TSP-RT-01-024, Rev. 0

Test Plan: WSRC-TR-2002-00153

SRT-RPP-2002-00047, Rev. 0

Test Exceptions: 24590-WTP-TEF-RT-03-005

R\&T Focus Area: Vitrification

Test Scoping Statement(s): S-62

\section{RHEOLOGICAL AND PHYSICAL PROPERTIES OF HANFORD, RADIOACTIVE LAW AZ-102 PRETREATED WASTE AND MELTER FEED (U)}

\author{
E. K. Hansen, 999-W \\ C. L. Crawford, 773-41A
}

NOVEMBER, 2003

Westinghouse Savannah River Company

Savannah River Site

Aiken, SC 29808

Prepared for the U.S. Department of Energy Under Contract Number DE-AC09-96SR18500

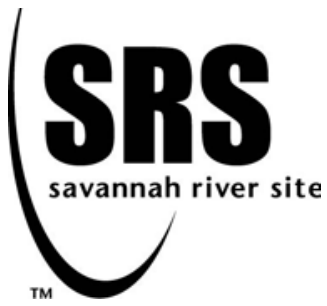


This page was intentionally left blank 


\section{TABLE OF CONTENTS}

WSRC-TR-2003-00390, REVISION 0

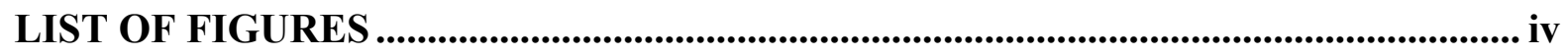

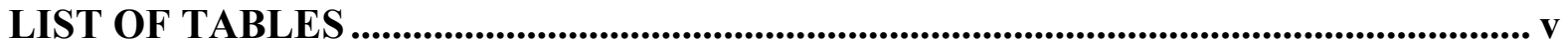

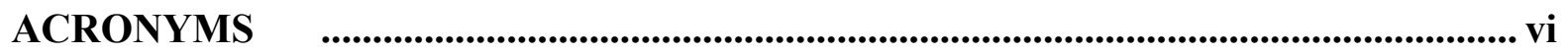

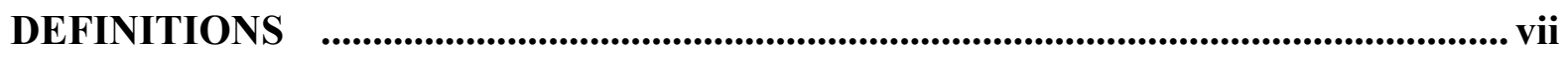

ABSTRACT

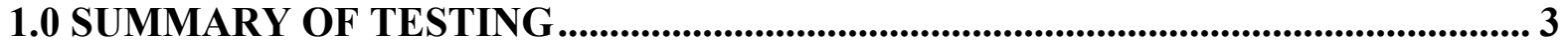

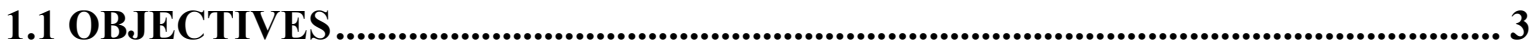

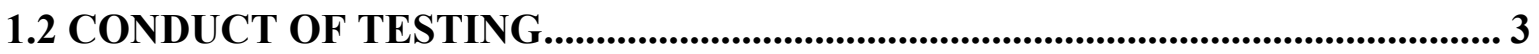

1.3 RESULTS AND PERFORMANCE AGAINST OBJECTIVES ............................ 4

1.4 QUALITY REQUIREMENTS...................................................................................... 5

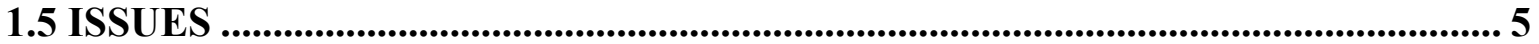

2.0 CD-ROM ENCLOSURES....................................................................................... 7

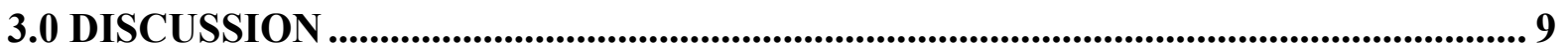

3.1 PURPOSE AND OBJECTIVES................................................................................... 9

3.2 GLASS FORMER CHEMICALS AND AZ-102 BATCH SHEET ........................ 11

3.3 LAW AZ-102 SAMPLE PREPARATION .............................................................. 13

3.3.1 Pretreated Waste ......................................................................................... 13

3.3.2 Melter Feed ............................................................................................................. 14

3.4 PHYSICAL PROPERTIES TESTING .................................................................... 18

3.4.1 Methodology for Measuring Physical Properties .................................................... 18

3.4.1.1 LAW AZ-102 Pretreated Waste Physical Properties .................................. 18

3.4.1.2 LAW AZ-102 Melter Feed Physical Properties ............................................ 19

3.4.2 Settling Results of LAW AZ-102 Melter Feed........................................................ 23

3.5 pH MEASUREMENT ................................................................................................. 25

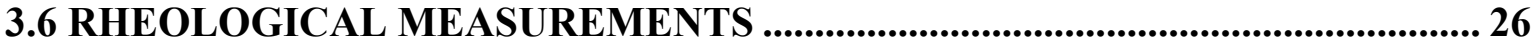

3.6.1 Instrumentation ............................................................................................ 26

3.6.2 Flow Curve Measurements Using Concentric Geometry .................................... 27

3.6.3 Yield Stress Measurement Using Vane Geometry ............................................. 29

3.6.4 LAW AZ-102 Pretreated Waste Rheology Results .............................................. 31

3.6.5 LAW AZ-102 Melter Feed Rheology Results ................................................ 32

3.6.6 Settled Solids Vane Measurement Results ....................................................... 35

3.7 PARTICLE SIZE DISTRIBUTION .................................................................. 37

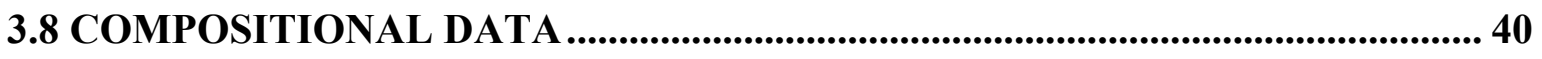

3.8.1 Pretreated Waste Composition ....................................................................... 40

3.8.2 Melter Feed Composition ............................................................................... 42

3.9 DISCUSSION ON BOUNDING PHYSICAL LIMITS AND DESIGN ISSUES ... 43

3.9.1 Settled Solids Shear Strength .............................................................................. 43

3.9.2 Transport Velocities and Homogeneous Mixing ................................................. 44

3.9.3 Rheology Issues....................................................................................................... 45

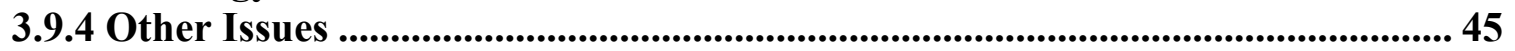

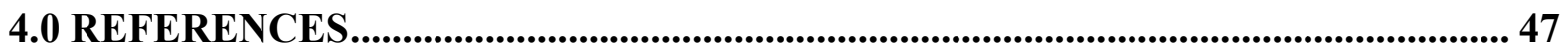

APPENDIX A. PARTICLE SIZE DISTRIBUTION DATA ...................................... 49

APPENDIX B. COMPOSITION OF GLASS FORMER CHEMICALS..................... 61

APPENDIX C. TABLE 12, SHEETS \#1, \#2, \#3 AND \# 5 ................................................ 63 


\section{LIST OF FIGURES}

Figure 3-1. GFCs Added to LAW AZ-102 1.3M Na Pre-Treated Feed .............................. 16

Figure 3-2. Settling of LAW AZ-102 1.3M Na Melter Feed.............................................. 20

Figure 3-3. Normalized Settling Curves for LAW AZ-102 Melter Feed ........................... 24

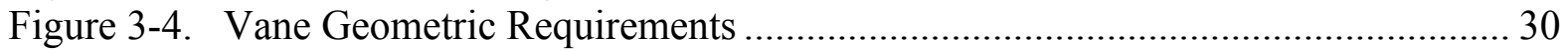

Figure 3-5. Typical Torque - Time/Displacement Curve ............................................. 30

Figure 3-6. LAW AZ-102 1.0M Na Pretreated Waste Flow Curve................................... 32

Figure 3-7. LAW AZ-102 1.3M Na Pretreated Waste Flow Curve.................................... 32

Figure 3-8. LAW AZ-102 1.0M Na Melter Feed, After 3 Days of Mixing......................... 33

Figure 3-9. LAW AZ-102 1.0M Na Melter Feed, After 7 Days of Mixing......................... 33

Figure 3-10. LAW AZ-102 1.3M Na Melter Feed, After 1 Day of Mixing ........................ 33

Figure 3-11. Vane Results of the LAW AZ-102 Settled Melter Feed................................ 37

Figure A- 1. Initial Volume PSD - 2040A Standard .................................................. 49

Figure A- 2. Initial Number PSD - 2040A Standard ....................................................... 50

Figure A- 3. Initial Volume PSD - 4350A Standard .................................................... 51

Figure A- 4. Initial Number PSD - 4350A Standard ..................................................... 52

Figure A- 5. Volume PSD - LAW AZ-102 1.3M Na Melter Feed - 1 day mixing ............. 53

Figure A- 6. Number PSD - LAW AZ-102 1.3M Na Melter Feed - 1 Day Mixing............ 54

Figure A- 7. Volume PSD - LAW AZ-102 1.0M Na Melter Feed - 3 Days Mixing .......... 55

Figure A- 8. Number PSD - LAW AZ-102 1.0M Na Melter Feed - 3 Days Mixing ......... 56

Figure A- 9. Volume PSD - LAW AZ-102 1.0M Na Melter Feed - 7 Days Mix ............... 57

Figure A- 10. Number PSD - LAW AZ-102 1.0M Na Melter Feed - 7 Days Mixing ........ 58

Figure A- 11. Final Volume PSD - 2040A Standard ..................................................... 59

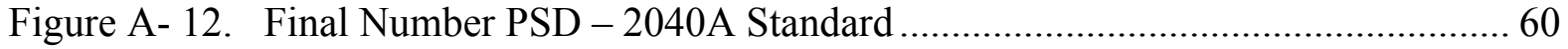




\section{LIST OF TABLES}

Table 3-1. Objectives from Test Exception [Ref. 2]....................................................... 9

Table 3-2. Glass Former Chemicals Utilized...................................................................... 11

Table 3-3. VSL GFC Batch Sheet LAWB98 for SRTC LAW AZ102 Pre-Treated Feed .... 12

Table 3-4 Original Undiluted LAW AZ-102 Pretreated Waste Properties and Quantity..... 13

Table 3-5. Diluted LAW Pretreated Waste Makeup........................................................... 14

Table 3-6. Glass Former Used For LAW AZ-102 Melter Feeds ............................................ 15

Table 3-7. Agitator Speeds During GFCs Addition and Extended Mixing .......................... 17

Table 3-8. Description of Mixing Tanks and Agitators....................................................... 17

Table 3-9. Physical Properties of AZ-102 Pretreated Waste ............................................... 19

Table 3-10. Physical Properties of LAW AZ-102 1.0M Na and 1.3M Na Melter Feed....... 23

Table 3-11. Normalized Interface Volume for LAW AZ-102 Melter Feed .......................... 25

Table 3-12. pH of the LAW AZ-102 Pretreated Wastes and Melter Feeds........................... 26

Table 3-13. M5 Measuring Head Specifications …………………...................................... 26

Table 3-14. NV and MV1 Rotor Specifications and Ramp Rates ....................................... 27

Table 3-15. Cole-Parmer NIST Traceable Newtonian Oil Standard ..................................... 28

Table 3-16. M5 Operability Checks Using NIST Traceable Viscosity Oil Standards ......... 29

Table 3-17. Settling Impact on LAW AZ-102 Melter Feed Flow Curves .............................. 34

Table 3-18. LAW AZ-102 Melter Feed Supernatant Viscosity ............................................ 35

Table 3-19. Settled Solids Height and Times for Vane Measurements ................................ 35

Table 3-20. Shear Strength and Observations of Settled LAW AZ-102 Melter Feed........... 36

Table 3-21. Summary of Particle Size Data for Standards ................................................... 38

Table 3-22. Summary of Particle Size Distribution Data for Melter Feeds........................... 40

Table 3-23. Volume of Pretreated Waste............................................................................ 40

Table 3-24. Calculated 1.0M Na and 1.3M Na LAW Pretreated Waste Compositional Data

Table 3-25. Calculated 1.0M Na and 1.3M Na LAW Melter Feed Compositional Data ..... 42

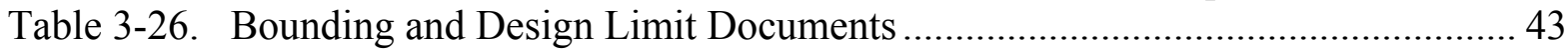

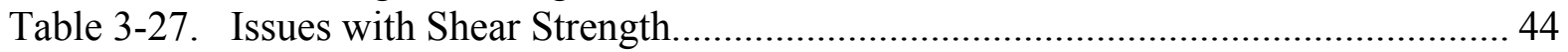




\section{ACRONYMS}

ITS Immobilization Technology Section

LAW Low Activity Waste

MFPV Melter Feed Preparation Vessel

NIST National Institute of Standards and Technology

N/A Not Applicable

N/M Not Measured

PSD Particle Size Distribution

QA Quality Assurance

QAPjP Quality Assurance Project Plan

RPD Relative Percent Difference

RPP River Protection Project

R\&T Research and Technology

SRS Savannah River Site

SRTC Savannah River Technology Center

Stdev Standard Deviation

VSL Vitreous State Laboratory

WTP Waste Treatment Plant 
WSRC-TR-2003-00390, REVISION 0

SRT-RPP-2003-00185, REVISION 0

\section{DEFINITIONS}

\begin{tabular}{|c|c|c|}
\hline Variable & Definition & Units \\
\hline Apparent viscosity & The measured shear stress divided by the measured shear rate. & $\begin{array}{l}\mathrm{Pa} \cdot \mathrm{s} \\
\mathrm{cP}\end{array}$ \\
\hline Density & Mass per unit volume. & $\mathrm{g} / \mathrm{mL}$ \\
\hline Flow curve/rheogram & Plot of shear stress versus shear rate. & N/A \\
\hline Interstitial solution & Solution contained between suspended, settled, or centrifuged solids. & N/A \\
\hline Newtonian Fluid & A fluid whose apparent viscosity is independent of shear rate. & N/A \\
\hline Non-Newtonian Fluid & A fluid whose apparent viscosity varies with shear rate. & N/A \\
\hline $\begin{array}{l}\text { Settled solids shear } \\
\text { strength }\end{array}$ & $\begin{array}{l}\text { The maximum shear stress as determined by the vane method for a } \\
\text { slurry sample that is allowed to settle for a specified amount of time. }\end{array}$ & $\mathrm{Pa}$ \\
\hline Solution & A liquid phase that can contain soluble solids. & grams \\
\hline Slurry & A mixture insoluble solids and solution & grams \\
\hline Supernatant Liquid & $\begin{array}{l}\text { A liquid phase overlying material deposited by settling, precipitation, } \\
\text { or centrifugation. }\end{array}$ & grams \\
\hline Solids Settling Rate & $\begin{array}{l}\text { Rate at which solids in a homogenized sample settle. The change in } \\
\text { the settled solids height as a function of time. }\end{array}$ & $\mathrm{cm} / \mathrm{sec}$ \\
\hline vol $\%$ centrifuged solids & $\begin{array}{l}\text { The volume of the solids layer that separates from the bulk slurry } \\
\text { after } 1 \text { hour of centrifugation at } 1000 \text { gravities divided by the total } \\
\text { sample volume on a percentage basis. These centrifuged solids will } \\
\text { contain interstitial solution. }\end{array}$ & vol $\%$ \\
\hline vol $\%$ settled solids & $\begin{array}{l}\text { The percentage of the volume of the slurry sample that the settled } \\
\text { solids occupy after settling for } 72 \text { hours under one gravity. These } \\
\text { settled solids will contain interstitial solution. }\end{array}$ & vol $\%$ \\
\hline wt $\%$ centrifuged solids & $\begin{array}{l}\text { The mass of the solids layer that separates from the bulk slurry after } \\
1 \text { hour of centrifugation at } 1000 \text { gravities divided by the total bulk } \\
\text { slurry sample mass on a percentage basis. These centrifuged solids } \\
\text { will contain interstitial solution. }\end{array}$ & $\mathrm{wt} \%$ \\
\hline $\mathrm{wt} \%$ oven dried solids & $\begin{array}{l}\text { The percent mass of the centrifuged solids remaining after removing } \\
\text { volatiles including free water by drying at } 105+5^{\circ} \mathrm{C} \text { for } 24 \text { hours. }\end{array}$ & $\mathrm{wt} \%$ \\
\hline $\mathrm{wt} \%$ settled solids & $\begin{array}{l}\text { The percentage (mass basis) of settled solids present in the sample. } \\
\text { Calculated by dividing the mass of the settled solids by the mass of } \\
\text { sample. }\end{array}$ & $\mathrm{wt} \%$ \\
\hline $\begin{array}{l}\text { wt } \% \text { soluble solids in } \\
\text { supernatant }\end{array}$ & $\begin{array}{l}\text { Calculated by dividing the mass of the dried supernatant by the mass } \\
\text { of the supernatant prior to drying. }\end{array}$ & $\mathrm{wt} \%$ \\
\hline $\mathrm{wt} \%$ total oxides & $\begin{array}{l}\text { The percentage of the mass of the bulk sample that remains after } \\
\text { converting all non-volatile elements to oxides. Dried slurry calcined } \\
\text { at } 1050^{\circ} \mathrm{C} \pm 50^{\circ} \mathrm{C} \text { for } 1 \text { hour. }\end{array}$ & $\mathrm{wt} \%$ \\
\hline $\mathrm{wt} \%$ total solids & $\begin{array}{l}\text { The percentage of the mass of dried solids divided by the mass of the } \\
\text { slurry. }\end{array}$ & $\mathrm{wt} \%$ \\
\hline wt $\%$ undissolved solids & $\begin{array}{l}\text { Calculated by dividing the calculated mass of the undissolved solids } \\
\text { by the mass of the bulk solids. }\end{array}$ & $\mathrm{wt} \%$ \\
\hline Yield Stress & $\begin{array}{l}\text { The minimum stress required to initiate flow. Determined by fitting } \\
\text { measured flow curve using non-Newtonian rheological models. }\end{array}$ & $\mathrm{Pa}$ \\
\hline
\end{tabular}


WSRC-TR-2003-00390, REVISION 0

SRT-RPP-2003-00185, REVISION 0

This page intentionally left blank.

- viii - 


\title{
WSRC-TR-2003-00390, REVISION 0 \\ SRT-RPP-2003-00185, REVISION 0
}

\begin{abstract}
The physical and rheological properties, $\mathrm{pH}$, and particle size distribution (PSD) of a radioactive Hanford tank sample, 241-AZ-102 (Envelope B) pretreated by the reference River Protection Program (RPP) Waste Treatment Plant (WTP) pretreatment process at SRTC [Ref. 5] were measured. The pretreated waste was received at a concentration of 4.38M Na and then diluted and blended with glass former chemicals (GFCs) to make up the corresponding melter feeds. The low activity waste (LAW) pretreated wastes at two sodium molarities of $1.0 \mathrm{M} \mathrm{Na}$ and 1.3M Na [Ref. 2] were characterized first and then their respective melter feeds were characterized after the addition of GFCs. As expected, the 1.0M Na and 1.3M Na pretreated wastes have similar properties due to the small change in sodium molarity. The 1.0M Na melter feed was characterized after 3 days and 7 days of mixing which showed no significant differences in properties. This indicates that the $1.0 \mathrm{M} \mathrm{Na}$ melter feed is fairly stable at this sodium molarity.
\end{abstract}

The following technical issues were observed in the measured rheological properties of the melter feeds:

- Settling behavior of the melter feeds impacted the flow curves.

- Melter feeds are heterogeneous.

- Settled solids shear stress for the 1.3M Na melter feed exceeded the maximum operating shear strength limit (625Pa - Ref. 21).

- Settled solids shear strength increased as a function of measurement depth, indicating that a shear strength gradient was observed in the 1.0M Na melter feed.

- Settled solids in the 1.0M Na melter feed were observed to build strength within 30 minutes when not agitated. 
WSRC-TR-2003-00390, REVISION 0

SRT-RPP-2003-00185, REVISION 0

This page intentionally left blank. 
WSRC-TR-2003-00390, REVISION 0

SRT-RPP-2003-00185, REVISION 0

\subsection{SUMMARY OF TESTING}

\subsection{OBJECTIVES}

The objective of this task was to measure and report the physical and rheolgocical properties, $\mathrm{pH}$, and PSD of a radioactive Hanford tank sample, 241-AZ-102 (Envelope B) pretreated by the reference RPP-WTP pretreatment process [Ref. 5]. The pretreated LAW waste and melter feed samples were characterized at two different sodium molarities in accordance with the RPP-WTP Research and Technology (R\&T) guidelines for characterization [Ref. 1]. The initial LAW AZ-102 pretreated waste was received at a concentration of 4.38M Na. This pretreated waste was then diluted to two different sodium molarities of $1.0 \mathrm{M} \mathrm{Na}$ and $1.3 \mathrm{M}$ $\mathrm{Na}$. The LAW 1.0M Na and 1.3M Na pretreated wastes were characterized and then blended with RPP-WTP R\&T- approved GFCs [Ref. 4] to make melter feeds. The LAW 1.0M Na melter feed was characterized after 3 days and 7 days of continuous mixing and the LAW $1.3 \mathrm{M}$ Na melter feed was characterized after 1 day of continuous mixing. All characterization work as specified by WTP R\&T was performed [Ref. 2]. A more detailed description of the purpose and objectives of this task is provided in section 3.1.

\subsection{CONDUCT OF TESTING}

The radioactive1.0M Na and 1.3M Na LAW AZ-102 pretreated wastes were characterized for:

- density

- weight percent ( $\mathrm{wt} \%)$ total solids, and $\mathrm{wt} \%$ oxide solids

- $\mathrm{pH}$

- viscosity

The density was obtained using a graduated cone; the $\mathrm{wt} \%$ data using an oven/furnace and weighing balances; the $\mathrm{pH}$ using $\mathrm{pH}$ probes; and the viscosity by curve fitting the resulting flow curve as a Newtonian fluid.

The LAW AZ-102 pretreated wastes were blended with RPP-WTP R\&T approved GFCs [Ref. 4] to make melter feed. Laboratory scale mixing equipment was not determined nor scaled based on proposed LAW melter feed preparation vessel (MFPV) design/operating conditions. Mixing conditions were set by SRTC such that the condition of mixing (agitator speed) provided a well mixed product based on visual observation.

The LAW AZ-102 melter feeds were characterized for:

- settling rates

- total density, supernatant density, settled solids density, and centrifuged solids density

- $\quad w t \%$ centrifuged solids, wt $\%$ settled solids, wt $\%$ soluble solids in supernatant, wt $\%$ total solids, wt $\%$ oven dried solids, wt $\%$ undissolved solids, and $\mathrm{wt} \%$ total oxides

- volume percent (vol\%) settled solids and vol\% centrifuged solids

- $\mathrm{pH}$

- rheology (flow curves and shear vane measurements)

- particle size distribution (PSD) 


\section{WSRC-TR-2003-00390, REVISION 0 SRT-RPP-2003-00185, REVISION 0}

The settling data was obtained using graduated centrifuge cones. The density data was obtained using the graduated centrifuge cone and graduated cylinder; the $\mathrm{wt} \%$ data using an oven/furnace and weighing balances; the $\mathrm{pH}$ using $\mathrm{pH}$ probes; viscosity of the supernatant by curve fitting the resulting flow curves as a Newtonian fluid; reporting the largest stress measurement using the vane as the settled shear strength; and the PSD using laser scatter method.

The composition of the LAW pretreated wastes and melter feeds are to be calculated based on the original composition of the LAW 4.38M Na pretreated waste [Ref. 5] and the composition of the individual GFCs [Ref. 4].

\subsection{RESULTS AND PERFORMANCE AGAINST OBJECTIVES}

All the objectives in this task were met and are described in detail in section 3.1. Any discrepancies with respect to the objectives stated in reference 2 are also stated in section 3.1. These discrepancies did not impact the deliverables requested in reference 2 .

The physical properties (density and wt\% solids) results for the LAW AZ-102 $1.0 \mathrm{M} \mathrm{Na}$ and 1.3M Na pretreated wastes are presented in Table 3-9. The $\mathrm{pH}$ is presented in Table 3-12 and the viscosity in Figure 3-6 and Figure 3-7. Due to the small change in sodium molarity, the viscosities of the resulting pretreated wastes are similar.

The physical properties (density, wt $\%$ solids and vol\% solids) results for the LAW AZ-102 melter feeds are presented in Table 3-10. The melter feed flow curves are shown in Figure 3-8 through Figure 3-10. These melter feeds are settling slurries, such that required flow properties could not be properly quantified using existing bench top rheological instrumentation at SRTC. The rheological responses of these slurries with respect to the flow curve measurements are explained in Table 3-17. The melter feed flow curves were not fit to any of the rheological models recommended in reference 1, because these rheological models assume the fluid is non-Newtonian. The melter feed supernatants were analyzed as Newtonian fluids and the results are shown in Table 3-18. There are measurable differences in the $\mathrm{wt} \%$ soluble solids, densities, and viscosities of the pretreated wastes and melter feed supernatants, indicating some of the dry GFC solids had dissolved.

Even though the melter feed flow curves could not be analyzed using non-Newtonian rheological models, the viscosity and density of the melter feed supernatant were measured and the PSD and density of GFC particles are known such that these properties could potentially be used to estimate the required flow velocities and mixing parameters required to prevent settling using heterogeneous slurry correlations. These heterogeneous slurry correlations and their applicability to the RPP-WTP design/operations must be thoroughly understood prior to use.

The settled solids shear strengths of the AZ-102 melter feeds are shown in Figure 3-11 and observations reported in Table 3-20. The 1.3M Na melter feed settled solids shear strength exceeded the design basis value of $625 \mathrm{~Pa}$. The particle size distribution is provided in Table 3-22 and shows slight differences between the 1.0M Na and 1.3M Na melter feed, with the $1.3 \mathrm{M}$ Na having slightly larger particles. 


\section{WSRC-TR-2003-00390, REVISION 0 SRT-RPP-2003-00185, REVISION 0}

The 1.0M Na melter feeds has essentially the same physical, rheological, PSD, and $\mathrm{pH}$ properties after 3 days and 7 days of continuous mixing. The settled solids shear strengths were different between the two samples, but this could be due to the amount of time the samples were allowed to settle undisturbed prior to the vane measurements, how the solids settled out and the location of the measurement in the samples. There was also a settled solids shear strength gradient observed on one of the 1.0M Na samples where two different depths were measured and the settled solids shear strength increased as the depth increased. A more detailed description of the settled solids shear strength results are provided in section 3.6.6.

The calculated chemical composition of the LAW pretreated wastes and melter feeds are provided in section 3.8 .

\subsection{QUALITY REQUIREMENTS}

This work was conducted in accordance with the RPP-WTP QA requirements specified for work conducted by SRTC as identified in DOE IWO MOSRLE60. Researchers followed the SRTC QA program, which has been approved by WTP, and the WSRC QA Management Plan (WSRC-RP-92-225). The program applied the appropriate QA requirements for this task, as indicated by the QA Plan Checklist in section IX of the Task Technical and Quality Assurance Plan [Ref. 3].

Analytical sample labeling and tracking complied with established procedures (WSRC Manual L1, Procedure 7.15). The Immobilization Technology Section (ITS) conducted all analyses using the routine level QA program. Calibrated measuring equipment was utilized. The Task Technical and Quality Assurance Plan [Ref. 3] provided the quality requirements for this work. NQA-1 1989, Basic and Supplementary Requirements and NQA-2a 1990, Part 2.7 were applied as appropriate,

\subsection{ISSUES}

The section discusses the potential impact that the measured properties will have on the known design bases, design or operating conditions of the RPP-WTP vitrification plant.

The 1.3M Na melter feed settled solids exceeded the maximum operating shear strength limit of $625 \mathrm{~Pa}$ [Ref. 21]. The agitator start up torque planned in the design is 1.5 times this maximum settled solids shear strength value [Ref. 25]. This maximum operating shear strength was calculated using the maximum horsepower and bottom blade design of the Defense Waste Processing Facility (DWPF) agitators in reference 21 and is being compared with to the project's actual physical and rheological properties data as it becomes available. Additionally, no supporting calculation exists to determine if the agitator, given $625 \mathrm{~Pa}$ shear strength, can completely re-homogenize the mixing vessel. Additional issues related to the maximum shear strength are provided in section 3.9.1. 
The lower consistency limit for LAW melter feed is 0.4 centipoises (cP) [Ref. 21]. The results of the melter feed settling tests indicate that there will be settling issues with these slurries. Calculations nor physical testing for determining the minimum deposition velocity or a velocity required to produce a homogenous mixture in the pipelines has been performed. Additional issues related to the lower viscosity limit are provided in section 3.9.2.

The issue of settled solids, when measuring the settled solids shear strength can be both a function of time and the level of settled solids. The present bench scale tests do not investigate these issues. Additionally, the viscosity of the carrier fluid (supernatant) of the LAW melter feed should be analyzed. This information may be useful in engineering calculations if the resulting melter feeds are considered as settling slurries. Additional information is provided in section 3.9.3. 


\subsection{CD-ROM ENCLOSURES}

The following EXCEL worksheet is enclosed in the attached CD. The EXCEL worksheet contains the raw rheological data as required per Table 12, Sheet \#4 [Ref. 1]. Table 12 sheets $\# 1, \# 2, \# 3$ and $\# 5$ are attached to this document in Appendix C. EXCEL worksheet provided in the CD is labeled LAW AZ-102 Radioactive Table 12, Sheet \# 4. 
WSRC-TR-2003-00390, REVISION 0

SRT-RPP-2003-00185, REVISION 0

This page intentionally left blank. 
WSRC-TR-2003-00390, REVISION 0

SRT-RPP-2003-00185, REVISION 0

\subsection{DISCUSSION}

\subsection{PURPOSE AND OBJECTIVES}

The purpose and objective of this task was to measure and report the physical and rheological properties, $\mathrm{pH}$, and PSD of a radioactive Hanford tank sample, 241-AZ-102 (Envelope B) pretreated by the reference RPP-WTP pretreatment process at SRTC [Ref. 5]. The LAW pretreated wastes and melter feeds were characterized at two different sodium molarities in accordance with RPP-WTP R\&T guidelines for characterization [Ref. 1]. The initial AZ-102 pretreated waste was received at a concentration of $4.38 \mathrm{M} \mathrm{Na}$. This pretreated waste was then diluted to two different sodium molarities of $1.0 \mathrm{M} \mathrm{Na}$ and $1.3 \mathrm{M} \mathrm{Na}$. After the $1.0 \mathrm{M} \mathrm{Na}$ and $1.3 \mathrm{M}$ Na pretreated wastes were characterized, these waste streams were blended with the project approved GFCs [Ref. 4] to make melter feeds. The physical and rheological properties and $\mathrm{pH}$ of the resulting melter feeds were measured using the methods outlined in the RPP-WTP guidelines [Ref. 1], unless otherwise stated in this document.

The properties and conditions required for measurement of the LAW AZ-102 1.0M Na and 1.3M Na pretreated wastes and melter feeds are listed in Table 3-1. These properties and conditions are specified in the R\&T test exception [Ref. 2]. The PSD was performed in accordance with reference 2 .

Table 3-1. Objectives from Test Exception [Ref. 2]

\begin{tabular}{|c|c|c|c|c|c|}
\hline \multirow{3}{*}{ Measurements and Conditions } & \multicolumn{2}{|c|}{$1.3 \mathrm{M} \mathrm{Na}$} & \multicolumn{3}{|c|}{$1.0 \mathrm{M} \mathrm{Na}$} \\
\hline & \multirow{2}{*}{$\begin{array}{l}\text { Pretreated } \\
\text { waste }\end{array}$} & \multirow{2}{*}{$\begin{array}{c}\text { Melter } \\
\text { Feed }\end{array}$} & \multirow{2}{*}{$\begin{array}{l}\text { Pretreated } \\
\text { waste }\end{array}$} & \multicolumn{2}{|c|}{$\begin{array}{l}\text { Melter Feed } \\
\text { (mixing times) }\end{array}$} \\
\hline & & & & $(24 \mathrm{hrs})^{* * *}$ & (7 days) \\
\hline 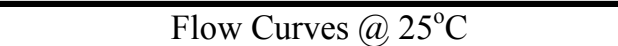 & $\overline{\mathbf{X}}$ & $\overline{\mathbf{X}}$ & $\overline{\mathbf{X}}$ & $\overline{\mathbf{X}}$ & $\bar{X}$ \\
\hline $\begin{array}{c}\text { Vane@ room temp. - Settled at least } \\
2 \text { days }\end{array}$ & $\mathrm{N} / \mathrm{A}$ & $\mathbf{X}$ & N/A & $\mathbf{X}$ & $\mathbf{X}$ \\
\hline Flow Curve of supernatant @25 ${ }^{\circ}{ }^{*}$ & $\mathrm{~N} / \mathrm{A}$ & $\mathbf{X}$ & $\mathrm{N} / \mathrm{A}$ & $\mathbf{X}$ & $\mathbf{X}$ \\
\hline pH@ room temperature & $\mathbf{X}$ & $\mathbf{X}$ & $\mathbf{X}$ & $\mathbf{X}$ & $\mathbf{X}$ \\
\hline Total solids & $\mathbf{X}$ & $\mathrm{N} / \mathrm{A}$ & $\mathbf{X}$ & $\mathrm{N} / \mathrm{A}$ & $\mathrm{N} / \mathrm{A}$ \\
\hline Total oxide & $\mathbf{X}$ & $\mathrm{N} / \mathrm{A}$ & $\mathbf{X}$ & $\mathrm{N} / \mathrm{A}$ & $\mathrm{N} / \mathrm{A}$ \\
\hline $\begin{array}{c}\text { Solids analysis via 24590-WTP-GPG- } \\
\text { RTD-001 }\end{array}$ & $\mathrm{N} / \mathrm{A}$ & $\mathbf{X}$ & $\mathrm{N} / \mathrm{A}$ & $\mathbf{X}$ & $\mathbf{X}$ \\
\hline Settling Test@ room temperature & $\mathrm{N} / \mathrm{A}$ & $\mathbf{X}$ & $\mathrm{N} / \mathrm{A}$ & $\mathbf{X}$ & $\mathbf{X}$ \\
\hline $\begin{array}{l}\text { Particle size distribution- sample diluted } \\
\text { with } \mathrm{NaOH} \text { solution*** }\end{array}$ & $\mathrm{N} / \mathrm{A}$ & $\mathbf{X}$ & $\mathrm{N} / \mathrm{A}$ & $\mathbf{X}$ & $\mathbf{X}$ \\
\hline Approved GFCs Utilization & $\mathrm{N} / \mathrm{A}$ & $\mathbf{X}$ & $\mathrm{N} / \mathrm{A}$ & $\mathbf{X}$ & $\mathbf{X}$ \\
\hline Approved GFC batch sheet & $\mathrm{N} / \mathrm{A}$ & $\mathbf{X}$ & $\mathrm{N} / \mathrm{A}$ & $\mathbf{X}$ & $\mathbf{X}$ \\
\hline Mixing at room temperature & $\mathrm{N} / \mathrm{A}$ & $\mathbf{X}$ & $\mathrm{N} / \mathrm{A}$ & $\mathbf{X}$ & $\mathbf{X}$ \\
\hline Reporting of Results in WTP format & $\mathbf{X}$ & $\mathbf{X}$ & $\mathbf{X}$ & $\mathbf{X}$ & $\mathbf{X}$ \\
\hline \multicolumn{6}{|c|}{$\begin{array}{l}\text { * SRTC added this measurement } \\
* * \text { Actual measurements were performed after } 3 \text { days of mixing. See discrepancies in this section. } \\
\text { *** An LAW AZ-102 pretreated waste simulant was used in place of } \mathrm{NaOH} \text { solution. See discrepancies in this } \\
\text { section. }\end{array}$} \\
\hline
\end{tabular}


The composition of the LAW pretreated wastes and melter feeds were calculated based on the original composition of the LAW AZ-102 4.38M Na pretreated waste [Ref. 5] and the composition of the individual GFCs [Ref. 4].

The discrepancies in this task were:

- The 24-hr measurement after mixing the LAW 1.0M Na AZ-102 melter feed [Ref. 2] did not occur until after 3 days of continuous mixing. This was due to an unforeseen radiological issue that closed the access to the laboratories for 2 days. This radiological issue was not related to this sample. In this document, the measurement date will reflect 3 days of mixing.

- $\mathrm{NaOH}$ solution was specified in the test exception [Ref. 2] as the carrier fluid for PSD measurements. An LAW AZ-102 pretreated waste simulant was used in place of the $\mathrm{NaOH}$ solution. The LAW AZ-102 pretreated waste simulant was diluted to the calculated $\mathrm{Na}$ molarity of the melter feeds and then filtered through a 0.2 micron filter to remove particulates prior to use.

- The $\mathrm{wt} \%$ solids and $\mathrm{wt} \%$ total oxide for the $1.0 \mathrm{M}$ and $1.3 \mathrm{M} \mathrm{Na}$ pretreated wastes were measured on the initial dilution of the $4.38 \mathrm{M}$ Na pretreated waste. Na analysis of these initial pretreated waste indicated they were low in Na concentration. The samples were evaporated and the $\mathrm{wt} \%$ total solids and $\mathrm{wt} \%$ total oxide for the $1.0 \mathrm{M} \mathrm{Na}$ and $1.3 \mathrm{M} \mathrm{Na}$ pretreated wastes were calculated based on the initial analyses of the dilute wastes. Additional details are provided in section 3.3.1.

- The density of the pretreated waste was not measured using a graduated cylinder [Ref.1]. Densities of the LAW AZ-102 pretreated wastes were determined as described in section 3.4.1.1.

- Sonication of the melter feed was not performed since the particle size analyzer does not have sonication capabilities. Details of the PSD technique used are provided in section 3.7 .

All properties listed in Table 3-1 were obtained using the methods outlined in the RPP-WTP guidelines document [Ref. 1], hence meeting the objectives of this task. All work was performed in a warm radiological hood. 
WSRC-TR-2003-00390, REVISION 0

SRT-RPP-2003-00185, REVISION 0

\subsection{GLASS FORMER CHEMICALS AND AZ-102 BATCH SHEET}

The GFCs utilized in this task are listed in Table 3-2 and are those approved by RPP-WTP R\&T [Ref. 4].

Table 3-2. Glass Former Chemicals Utilized

\begin{tabular}{|c|c|c|c|}
\hline $\begin{array}{c}\text { Oxide } \\
\text { Added }\end{array}$ & Mineral & Grade & Vendor \\
\hline $\mathrm{Al}_{2} \mathrm{O}_{3}$ & Kyanite $-\mathrm{Al}_{2} \mathrm{O}_{2}-\mathrm{SiO}_{2}$ & Raw -325 Mesh & Kyanite Mining Corp. \\
\hline $\mathrm{B}_{2} \mathrm{O}_{3}$ & Boric Acid $-\mathrm{H}_{3} \mathrm{BO}_{3}$ & Technical Grade-Granular & U.S. Borax \\
\hline $\mathrm{Na}_{2} \mathrm{O}$ & $\mathrm{Na}_{2} \mathrm{CO}_{3}$ Anhydrous & Dense Soda Ash & Solvay Minerals \\
\hline $\mathrm{CaO}$ & ${\mathrm{Wolllastonite}-\mathrm{CaSiO}_{3}}_{\mathrm{Fe}_{2} \mathrm{O}_{3}}$ & NYADM325 & NYCO \\
\hline $\mathrm{Fe}_{2} \mathrm{O}_{3}$ & $\mathrm{Li}_{2} \mathrm{CO}_{3}$ & Technical Grade & Chemettal-Foote \\
\hline $\mathrm{Li}_{2} \mathrm{O}$ & Olivine $-\mathrm{MgSiO}_{3}$ & $\# 180$ & Unimin Corp. \\
\hline $\mathrm{MgO}$ & $\mathrm{SiO}_{2}$ & SCS-75 & U.S. Silica \\
\hline $\mathrm{SiO}_{2}$ & $\mathrm{Rutile} \mathrm{TiO}_{2} / \mathrm{Fe}_{2} \mathrm{O}_{3}$ & Air Floated Rutile 94 & Chemalloy Co. \\
\hline $\mathrm{TiO}_{2}$ & $\mathrm{ZnO}_{\mathrm{ZnO}}$ & Kadox 920 & Zinc Corp America \\
\hline $\mathrm{ZnO}$ & $\mathrm{ZrSiO}$ & Zircon Flour & American Mineral Inc. \\
\hline $\mathrm{ZrO}$ & & &
\end{tabular}

The chemical composition of the LAW AZ-102 pre-treated waste was provided to Vitreous State Laboratories (VSL). In return, VSL then provided a GFC blend composition spreadsheet, LAWB96, as shown in Table 3-3. SRTC determined the mass of GFCs and the weight percent distribution of each of the GFCs for 1 mole of sodium. The results of the $\mathrm{wt} \%$ GFCs in the blend are shown in Table 3-3. These calculated values were used to determine the GFCs necessary to support the melter feed mixing tasks in section 3.3.2. 
WSRC-TR-2003-00390, REVISION 0 SRT-RPP-2003-00185, REVISION 0

Table 3-3. VSL GFC Batch Sheet LAWB98 for SRTC LAW AZ102 Pre-Treated Feed

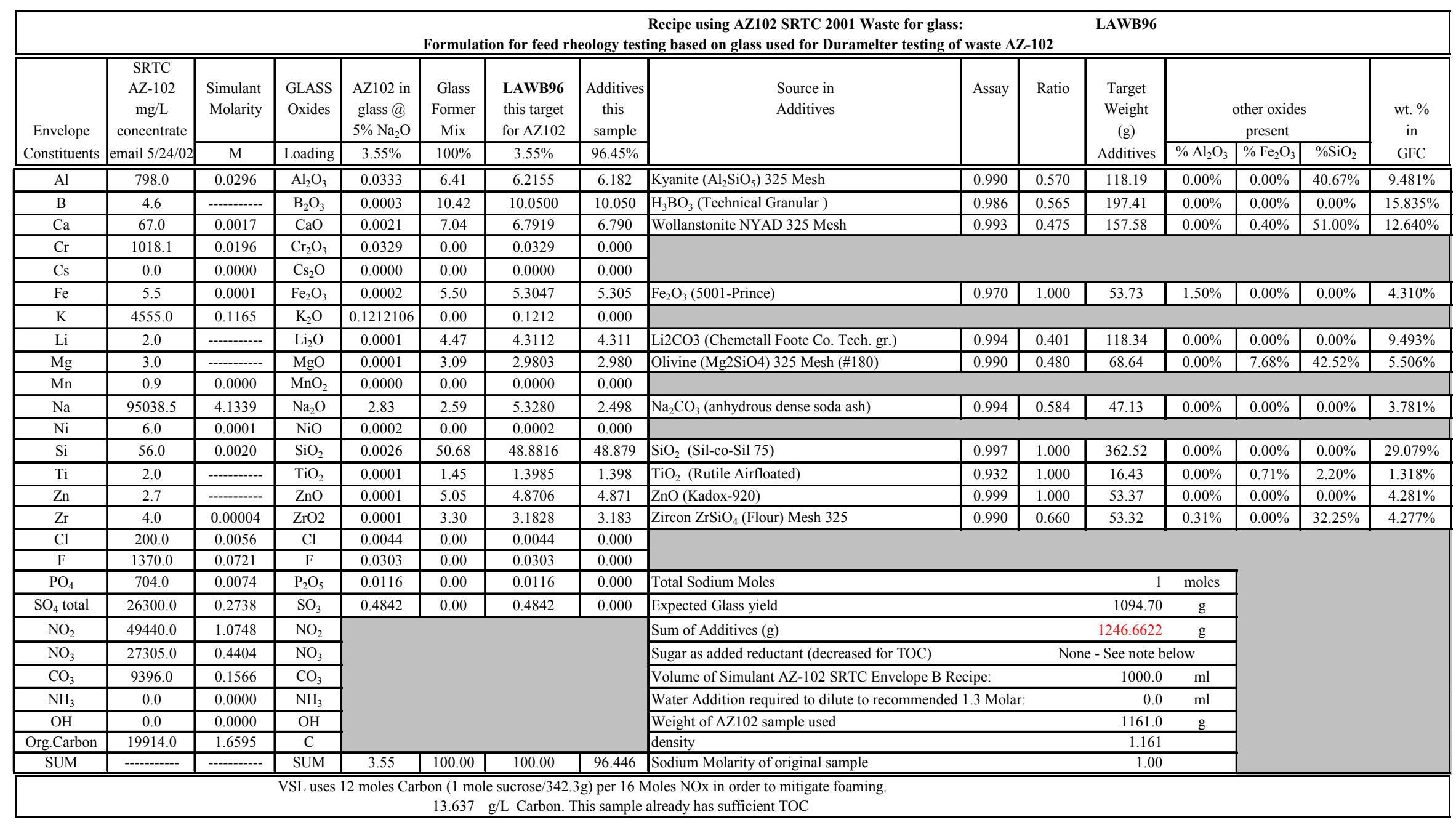




\subsection{LAW AZ-102 SAMPLE PREPARATION}

\section{WSRC-TR-2003-00390, REVISION 0 SRT-RPP-2003-00185, REVISION 0}

\subsubsection{Pretreated Waste}

A detailed description of the preparation of the radioactive LAW AZ-102 tank sample through the RPP-WTP pretreatment process is part of another test program at SRTC and is provided in another report [Ref. 5]. This report also provides the chemical composition and density of the LAW AZ-102 pretreated waste. The Na molarity, physical properties, and quantity of the original pretreated waste provided for this task is shown in Table 3-4. This 4.38M Na pretreated waste contained precipitated white solids and the solution was yellow in color. The precipitated white solids were easily suspended and homogenized upon slight agitation of the sample. The presence of trace amounts of fine white solids particles in the LAW AZ-102 pretreated waste could have been due to the fact that this concentrated pretreated waste was originally concentrated back in May of 2000 and was stored in a sealed poly bottle at ambient laboratory temperatures for over 3 years prior to the current physical and rheological properties and $\mathrm{pH}$ testing. It should be noted that these trace white solids particles were not observed in the original LAW AZ-102 evaporator waste concentrate [Ref. 5]. Further identification and analysis of these precipitated white solids was not within the scope of this task.

Table 3-4 Original Undiluted LAW AZ-102 Pretreated Waste Properties and Quantity

\begin{tabular}{|c|c|c|c|}
\hline Na Molarity & Density $(\mathrm{g} / \mathrm{mL})$ & $\mathrm{wt} \%$ total solids & Mass of sample $(\mathrm{g})$ \\
\hline 4.38 & 1.16 & 25 & $\sim 104$ \\
\hline
\end{tabular}

Targeted $\mathrm{Na}$ molarity concentrations of 1.0M Na and 1.3M Na [Ref. 2], mixing conditions, and the type of analyses required are stated in Table $3-1$. The amounts of $4.38 \mathrm{M} \mathrm{Na}$ pretreated waste required for making up the $1.0 \mathrm{M} \mathrm{Na}$ and $1.3 \mathrm{M} \mathrm{Na}$ pretreated wastes are shown in Table 3-5. The amount of DI water used to dilute the original waste to the targeted $\mathrm{Na}$ molarity values was calculated using the density, $\mathrm{Na}$ molarity, and mass of the $4.38 \mathrm{M} \mathrm{Na}$ pretreated waste used. The pretreated waste was homogenized and analyzed for Na molarity, density, $w \mathrm{t} \%$ total solids, and $\mathrm{wt} \%$ total oxide. The initial $\mathrm{Na}$ analysis indicated that both the $1.0 \mathrm{M} \mathrm{Na}$ and $1.3 \mathrm{M} \mathrm{Na}$ pretreated wastes were below the target sodium concentrations. This could have been due to the uncertainty of the $\mathrm{Na}$ analysis, the density of the original $4.38 \mathrm{M}$ $\mathrm{Na}$ pretreated waste, or the method used to calculate the targeted molarities. A calculated amount of water was evaporated from the samples to obtain the targeted sodium molarities and the results are shown in Table 3-5. Confirmatory samples were analyzed for sodium concentration and the results are shown in Table 3-6. Rheology (flow curves), density, and $\mathrm{pH}$ measurements were performed on the final pretreated wastes, with the intent to recover as much of the pretreated waste material as possible to accommodate for the melter feed tests. The $\mathrm{wt} \%$ total solids and $\mathrm{wt} \%$ total oxide solids were calculated from the original diluted measurements and are described in section 3.4.1.1. The mass and density of the final LAW AZ-102 1.0M Na and 1.3M Na pretreated wastes available for melter feed work are shown in Table 3-6. Both the 1.0M Na and 1.3M Na LAW AZ-102 pretreated wastes were a clear yellow fluid with a small quantity (that could not be quantified) of white precipitated solids. 
WSRC-TR-2003-00390, REVISION 0

SRT-RPP-2003-00185, REVISION 0

Table 3-5. Diluted LAW Pretreated Waste Makeup

\begin{tabular}{|c|c|c|c|}
\hline $\begin{array}{c}\text { Diluted } \\
\text { Pretreated } \\
\text { Waste }\end{array}$ & $4.38 \mathrm{M} \mathrm{Na}$ Feed Used & DI water added & DI water evaporated \\
\cline { 2 - 4 } & 62.347 & 170.893 & 13.259 \\
\hline $1.0 \mathrm{M} \mathrm{Na}$ & 41.574 & 79.35 & 21.432 \\
\hline $1.3 \mathrm{M} \mathrm{Na}$ & &
\end{tabular}

\subsubsection{Melter Feed}

Given the Na molarity, density, and mass of the pretreated feed, the quantity of each individual GFC was determined using Equation 3-1:

Equation 3-1 $\quad m_{G F C, i, j}=\frac{\tilde{M} \cdot M_{j} \cdot m_{j} \cdot w t_{G F C, i}}{1000 \cdot \rho_{j} \cdot 100 \%}$

where: $\mathrm{m}_{\mathrm{GFC}, \mathrm{ij}}=$ mass of a specific glass former chemical (grams)

$\tilde{M}=$ Total mass of GFCs per mole of $\mathrm{Na}$ (from Table 3-3)

$\mathrm{M}_{\mathrm{j}}=\mathrm{Na}$ molarity of pretreated waste $\mathrm{j}$ (moles $\mathrm{Na} /$ Liter)

$\rho_{\mathrm{j}}=$ density of pretreated waste $\mathrm{j}(\mathrm{g} / \mathrm{mL})$

$\mathrm{m}_{\mathrm{j}}=$ mass of pretreated waste $\mathrm{j}(\mathrm{g})$

$\mathrm{wt}_{\mathrm{GFC}, \mathrm{i}}=$ weight percent of a specific GFC in the GFC batch (from Table 3-3)

The actual quantities of each GFC used for the LAW AZ-102 1.0M and 1.3M Na melter feeds are shown in Table 3-6. For a given melter feed composition, the individual GFCs were weighed and placed into a single large wide mouth plastic bottle. Upon completion of weighing out the GFCs, the bottle was capped and vigorously shaken to provide a homogenous mixture of blended solids.

Laboratory mixing equipment was selected based on the calculated volume of melter feed that would result from the blending of the pretreated waste with the blended GFCs. The mixing equipment used for the LAW AZ-102 Na 1.0M Na and 1.3M Na melter feeds is described in Table 3-8. The plastic caps used for the mixing vessels were predrilled with holes slightly off-center and slightly larger than the diameter of the agitator shaft. The holes were placed slightly off-center to allow for better mixing, since there were no baffles present in any of the mixing vessels. 
WSRC-TR-2003-00390, REVISION 0

SRT-RPP-2003-00185, REVISION 0

Table 3-6. Glass Former Used For LAW AZ-102 Melter Feeds

\begin{tabular}{|c|c|c|c|c|c|}
\hline \multicolumn{3}{|c|}{ LAW AZ-102 Pretreated Waste Information } & Units & $1.0 \mathrm{M} \mathrm{Na}$ & $1.3 \mathrm{M} \mathrm{Na}$ \\
\hline \multicolumn{3}{|c|}{ Batching Sheet Used } & N/A & LAWB96 & LAWB96 \\
\hline \multicolumn{3}{|c|}{ Grams of GFCs per Mole of $\mathrm{Na}$} & Grams/mole & 1246.3317 & 1246.3317 \\
\hline \multicolumn{3}{|c|}{ Sodium Concentration of Pretreated Waste } & Na Molarity & 1.02 & 1.33 \\
\hline \multicolumn{3}{|c|}{ Mass of Pretreated Waste } & Grams & 193.508 & 88.711 \\
\hline \multicolumn{3}{|c|}{ Density of Pretreated Waste } & $\mathrm{g} / \mathrm{mL}$ & 1.049 & 1.073 \\
\hline \multicolumn{3}{|c|}{ Volume of Pretreated Waste } & $\mathrm{mL}$ & 184.53 & 82.68 \\
\hline \multicolumn{3}{|c|}{ Moles of sodium of Pretreated Waste } & Moles $\mathrm{Na}$ & 0.1878 & 0.1100 \\
\hline \multicolumn{6}{|c|}{ GFC Distribution } \\
\hline \multicolumn{2}{|l|}{ GFCs } & \multicolumn{2}{|c|}{ 1.0M Na Melter Feed } & \multicolumn{2}{|c|}{ 1.3M Na Melter Feed } \\
\hline Mineral & $\begin{array}{l}\text { Target } \\
\text { wt } \%\end{array}$ & $\begin{array}{l}\text { Target Mass } \\
\text { (g) }\end{array}$ & $\begin{array}{l}\text { Actual Mass } \\
\text { Added (g) }\end{array}$ & $\begin{array}{c}\text { Target Mass } \\
\text { (g) }\end{array}$ & $\begin{array}{l}\text { Actual Mass } \\
\text { Added (g) }\end{array}$ \\
\hline Kyanite $-\mathrm{Al}_{2} \mathrm{O}_{2}-\mathrm{SiO}_{2}$ & 9.439 & 22.10 & 22.102 & 12.95 & 12.953 \\
\hline Boric Acid $-\mathrm{H}_{3} \mathrm{BO}_{3}$ & 15.839 & 37.08 & 37.083 & 21.72 & 21.720 \\
\hline $\mathrm{Na}_{2} \mathrm{CO}_{3}$ Anhydrous & 3.782 & 8.85 & 8.850 & 5.19 & 5.190 \\
\hline Wollastonite $-\mathrm{CaSiO}_{3}$ & 12.644 & 29.60 & 29.602 & 17.34 & 17.340 \\
\hline $\mathrm{Fe}_{2} \mathrm{O}_{3}$ & 4.311 & 10.09 & 10.091 & 5.91 & 5.912 \\
\hline $\mathrm{Li}_{2} \mathrm{CO}_{3}$ & 9.495 & 22.23 & 22.233 & 13.02 & 13.020 \\
\hline Olivine $-\mathrm{MgSiO}_{3}$ & 5.507 & 12.89 & 12.890 & 7.55 & 7.550 \\
\hline $\mathrm{SiO}_{2}$ & 29.105 & 68.13 & 68.181 & 39.92 & 39.920 \\
\hline Rutile $\mathrm{TiO}_{2} / \mathrm{Fe}_{2} \mathrm{O}_{3}$ & 1.318 & 3.09 & 3.092 & 1.81 & 1.812 \\
\hline $\mathrm{ZnO}$ & 4.282 & 10.02 & 10.022 & 5.87 & 5.872 \\
\hline $\mathrm{ZrSiO}_{4}$ & 4.278 & 10.01 & 10.010 & 5.87 & 5.870 \\
\hline Total: & & 234.09 & 234.156 & 137.15 & 137.159 \\
\hline
\end{tabular}

First, the pretreated waste was added to the mixing vessel. The agitator impeller was then installed off-center and as close to the bottom of the mixing vessel as possible. The mixer was then started and the initial agitator speed was determined by visually observing for the presence of a vortex, such that the GFC solids could be easily entrained and dispersed by agitation. The GFCs were added manually with a spatula at a rate that could easily be blended into the mixture (based on visual observation). It took approximately 20 to 30 seconds for the mass of GFCs added to become entrained, during which time GFC addition was stopped and the mass of GFCs remaining to be added was recorded. The agitator speed was increased until an adequate vortex was again obtained and this cycle was repeated until all the GFCs were added. 
Figure 3-1 shows the LAW AZ-102 1.3M Na melter feed after all of the GFCs were added. The bubbles present were most likely due to air that was entrained during the GFC addition, and not by the vortex itself. The next day all the bubbles were gone. The effect of bubbles generated due to air entrainment during the addition of GFCs could be a factor within the WTP. The bubbles were common to both the $1.0 \mathrm{M} \mathrm{Na}$ and $1.3 \mathrm{M} \mathrm{Na}$ melter feeds during GFC addition. After all the GFCs were added, the slurry, agitator shaft/blade, and vessel cap were weighed. This was considered to be the baseline weight of the blended slurry. The addition rate of the GFCs and agitator speeds are shown in Table 3-7.

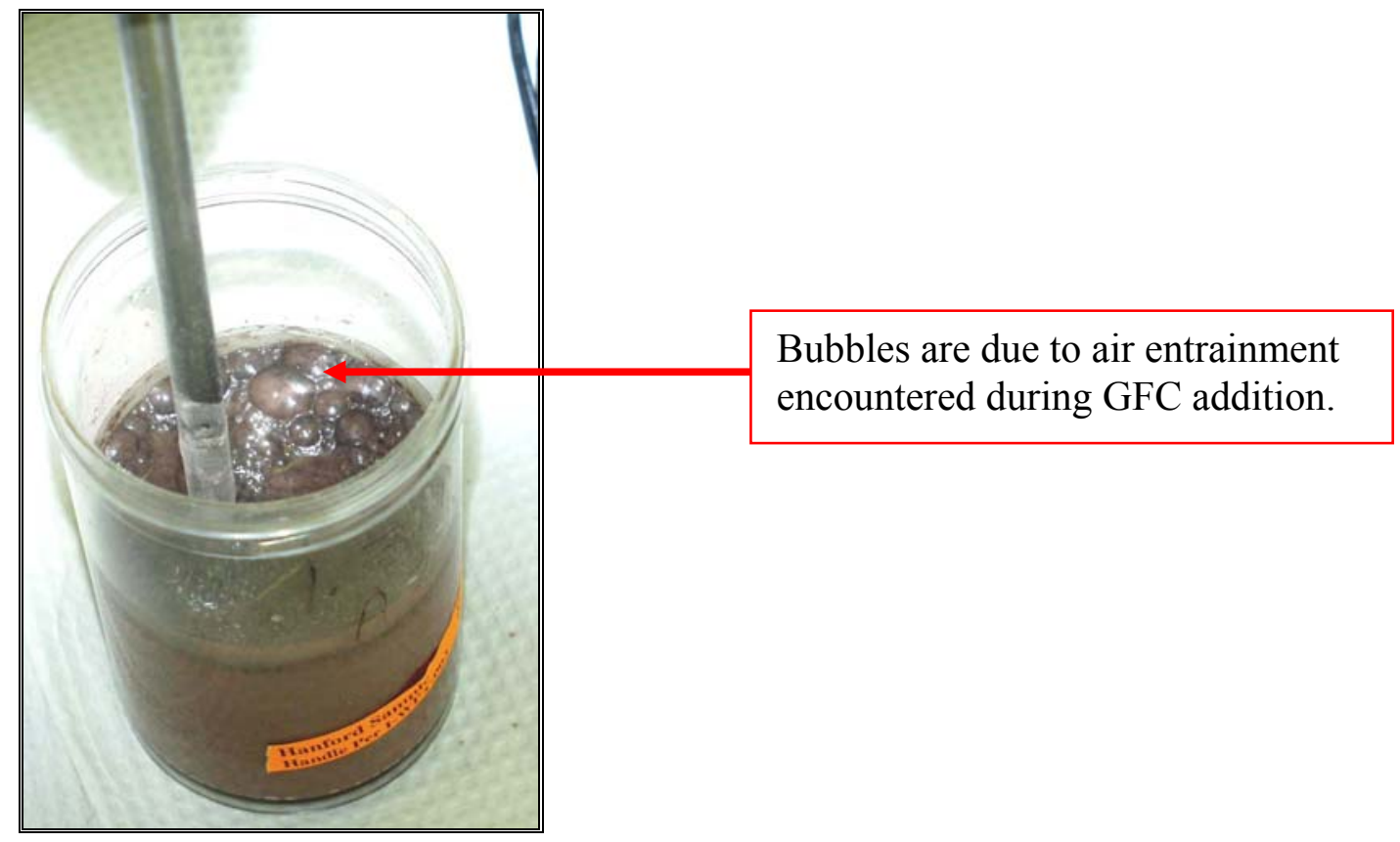

Figure 3-1. GFCs Added to LAW AZ-102 1.3M Na Pre-Treated Feed

The mixing system was reconfigured with the cap in place and the impeller located just offbottom. The final speed was then adjusted to provide an adequate vortex that resulted in a system where visual motion was observed everywhere and was maintained until the sample was analyzed. For the LAW AZ-102 1.0M Na melter feed, a sample was pulled after 3 days of mixing and a new agitator speed was set based on the new volume of material in the mixing vessel. The agitator speeds used for both the LAW AZ-102 1.0M Na and 1.3M Na melter feeds are shown in Table 3-7. One hour prior to pulling samples for analyses, the slurry, agitator shaft/blade, and tank cap were weighed and any mass difference against the baselines were compensated for with DI water since it was assumed that the mass lost was due to water evaporation only. The largest quantity of water loss was 5 grams after the initial 3 days of mixing the LAW AZ-102 1.0M Na melter feed. 
WSRC-TR-2003-00390, REVISION 0

SRT-RPP-2003-00185, REVISION 0

Table 3-7. Agitator Speeds During GFCs Addition and Extended Mixing

\begin{tabular}{|c|c|c|c|c|c|}
\hline \multicolumn{2}{|c|}{$\mathbf{1 . 0}$ M Na Melter Feed } & \multicolumn{3}{c|}{1.3 M Na Melter Feed } \\
\hline $\begin{array}{c}\text { Time } \\
\text { Minutes }\end{array}$ & $\begin{array}{c}\text { Agitator } \\
\text { Speed } \\
\text { RPM }\end{array}$ & $\begin{array}{c}\text { Cumulative } \\
\text { Mass of GFC } \\
\text { added (g) }\end{array}$ & $\begin{array}{c}\text { Time } \\
\text { Minutes }\end{array}$ & $\begin{array}{c}\text { Agitator } \\
\text { Speed } \\
\text { RPM }\end{array}$ & $\begin{array}{c}\text { Cumulative } \\
\text { Mass of GFC } \\
\text { added (g) }\end{array}$ \\
\hline Initial & 147 & 0 & Initial & 245 & 0 \\
\hline 2 & 193 & 26.52 & 3 & 285 & 46.70 \\
\hline 4 & 231 & 85.52 & 5 & 330 & 72.60 \\
\hline 7 & 265 & 216.89 & 7 & 400 & 103.88 \\
\hline 10 & 265 & 233.92 & 10 & 500 & 123.30 \\
\hline First 3 days & 325 & N/A & 13 & 550 & 137.12 \\
\hline Next 4 days & 213 & N/A & First day & 600 & N/A \\
\hline
\end{tabular}

Table 3-8. Description of Mixing Tanks and Agitators

\begin{tabular}{|c|c|c|}
\hline Description & 1.0 M Na Melter Feed & 1.3M Na Melter Feed \\
\hline Order of Chemical Additions & GFCs are blended & GFC are blended \\
\hline Mixing Time & 3 days +4 days & 24 hours total \\
\hline Impeller Diameter D (mm) & 50.69 & 38.30 \\
\hline Impeller Height H (mm) & 10.30 & 10.22 \\
\hline Impeller Width W (mm) & 2.21 & 2.33 \\
\hline Blade Length L (mm) & 12.40 & 6.10 \\
\hline Type of Impeller & Rushton & Rushton \\
\hline Tank Type & Right Cylinder Plastic Cup & Right Cylinder Plastic Cup \\
\hline Tank Inside Diameter $(\mathrm{mm})$ & 83.4 & 63.25 \\
\hline Tank Height $(\mathrm{mm})$ & 99.9 & 106.4 \\
\hline Number of Baffles & None & None \\
\hline Size of Baffles & None & None \\
\hline Depth of impeller & Just off bottom & Just off bottom \\
\hline Location of impeller $(\mathrm{mm})$ & Slightly off-centered & Slightly off-centered \\
\hline Comments & 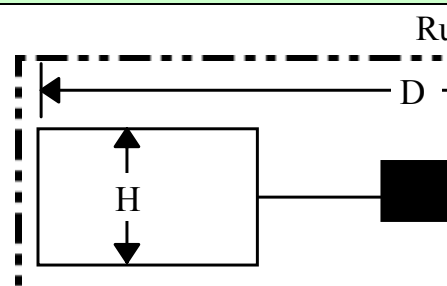 & $\longrightarrow \mathrm{L} \rightarrow \mathrm{L}^{\mathrm{W}}$ \\
\hline
\end{tabular}


When the LAW AZ-102 1.0M Na melter feed was sampled after 3 days of mixing and then weighed, it remained undisturbed for approximately 15 minutes and it was noted that a hard thin layer (not quantified) had already settled to the bottom of the mixing vessel. This indicated that some of the solids had settled and quickly formed a strong structure. Prior to placing the 1.0M Na melter feed back onto the mixing stand for 4 more days of mixing, the settled slurry was re-suspended using the Rushton impeller by scraping the bottom of the mixing vessel.

\subsection{PHYSICAL PROPERTIES TESTING}

The physical properties of the LAW AZ-102 pretreated wastes were analyzed for density, $\mathrm{wt} \%$ total solids, and $\mathrm{wt} \%$ total oxides.

The physical properties of the LAW AZ-102 melter feeds were measured in accordance with the project Guidelines [Ref. 1]. The following properties were either measured or calculated:

- density of slurry, density of supernatant, density of settled solids, and density of centrifuged solids $(\mathrm{g} / \mathrm{mL})$

- $\quad \mathrm{wt} \%$ and $\mathrm{vol} \%$ of settled solids and vol $\%$ centrifuged solids

- $\quad \mathrm{wt} \%$ total solids, wt $\%$ dried solids, wt $\%$ oven dried solids, $\mathrm{wt} \%$ undissolved solids (UDS), and $\mathrm{wt} \%$ total oxides

- $\quad$ settling rate (interfacial volume level versus time)

All the physical properties measurements were performed at room temperature (approximately 18 to $23^{\circ} \mathrm{C}$ ) unless otherwise specified. Rheological properties are physical properties and are discussed separately in section 3.6.

\subsubsection{Methodology for Measuring Physical Properties}

\subsubsection{LAW AZ-102 Pretreated Waste Physical Properties}

The density of the pretreated waste was determined using a $3.0 \mathrm{~mL}$ volume graduated cone. Triplicate samples of pretreated feed were placed into three graduated cones, filled to the $3.0 \mathrm{~mL}$ mark and weighed $\left(\mathrm{M}_{\mathrm{L}}\right)$ at room temperature. The density was calculated by dividing $\mathrm{M}_{\mathrm{L}}$ by the volume. The average density and standard deviation (Stdev) of the three readings are provided in Table 3-9. The method in which the $\mathrm{wt} \%$ total solids and $\mathrm{wt} \%$ total oxides were determined is described in section 3.4.1.2. The initial diluted AZ-102 pretreated wastes were characterized for $\mathrm{wt} \%$ total solids and $\mathrm{wt} \%$ total oxides. Due to limited amount of waste available for testing, the final $1.0 \mathrm{M} \mathrm{Na}$ and $1.3 \mathrm{M} \mathrm{Na}$ pretreated wastes $\mathrm{wt} \%$ total solids and $\mathrm{wt} \%$ total oxides were calculated from the initial $1.0 \mathrm{M} \mathrm{Na}$ and $1.3 \mathrm{M} \mathrm{Na}$ pretreated wastes that were analyzed for these properties. Note: There was not adequate sample volume to permit additional solids analysis without impacting the melter feed testing. The wt $\%$ total solids for the final pretreated wastes were re-calculated using Equation 3-2. 
Equation 3-2 $\quad P_{M D S, 2}=\frac{P_{M D S, 1} \cdot M_{T 1}}{M_{T 1}-M_{E v a p}}$

where:

$\mathrm{P}_{\mathrm{MDS}, 1}=\mathrm{wt} \%$ total solids of initial diluted pre-treated waste $(\%)$

$\mathrm{M}_{\mathrm{T} 1}=$ mass of initial diluted pretreated waste prior to evaporation (g)

$\mathrm{M}_{\text {evap }}=$ mass of water loss due to evaporation (g)

$\mathrm{P}_{\mathrm{MDS}, 2}=\mathrm{wt} \%$ total solids of final diluted pretreated waste $(\%)$

The same method was used to calculate the $\mathrm{wt} \%$ total oxides. The standard deviations are those of the errors from the initial diluted pretreated feed samples.

Table 3-9. Physical Properties of AZ-102 Pretreated Waste

\begin{tabular}{|c|c|c|c|c|c|}
\hline \multirow{2}{*}{ Physical Property } & \multirow{2}{*}{ Units } & \multicolumn{2}{|c|}{$\mathbf{1 . 0 M}$ Na pretreated waste } & \multicolumn{2}{c|}{$\mathbf{1 . 3 M}$ Na pretreated waste } \\
\cline { 3 - 6 } & & Average & Stdev & Average & Stdev \\
\hline Density - supernatant liquid & $\mathrm{g} / \mathrm{mL}$ & 1.049 & 0.005 & 1.072 & 0.006 \\
\hline $\mathrm{wt} \%$ total solids - $\mathrm{P}_{\mathrm{MDS}}$ & $\%$ & 6.34 & 0.03 & 8.14 & 0.05 \\
\hline $\mathrm{wt} \%$ total oxides - $\mathrm{P}_{\mathrm{MOX}}$ & $\%$ & 0.87 & 0.08 & 1.07 & 0.17 \\
\hline total oxides/total solids ratio & $\mathrm{g}_{\text {oxide }} / \mathrm{g}_{\text {solids }}$ & 0.137 & $\mathrm{~N} / \mathrm{A}$ & 0.132 & $\mathrm{~N} / \mathrm{A}$ \\
\hline
\end{tabular}

\subsubsection{LAW AZ-102 Melter Feed Physical Properties}

Below is a description of how a melter feed sample was handled and the variables calculated, in accordance with the project Guidelines procedure [Ref. 1]. Triplicate samples were run for each of LAW AZ-102 melter feeds. The samples for the settling tests, rheology, total oxides, and PSD were pulled using a $5 \mathrm{~mL}$ slurry pipette from the mixing vessel, while maintaining a slight vortex and good mixing.

Approximately 7 to $10 \mathrm{~mL}$ of the LAW AZ-102 melter feed (denoted slurry) was placed into a $10 \mathrm{~mL}$ volumetric graduated centrifuge cone. The mass $\left(\mathrm{M}_{\mathrm{B}}\right)$ and volume of the slurry were recorded. The sample was then allowed to settle for at least 3 days. A detailed description of the settling test is provided in section 3.4.2. After the settling test was completed, the total volume $\left(\mathrm{V}_{\mathrm{SB}}\right)$ of the sample and the volume of settled solids $\left(\mathrm{V}_{\mathrm{SS}}\right)$ were recorded. The error associated with this measurement is the total volume, which may be under or over estimated, based on how the meniscus was read (Figure 3-2). Additionally, the materials hanging onto the sides of the tube would slightly decrease the level of settled slurry and the total volume (Figure 3-2). 


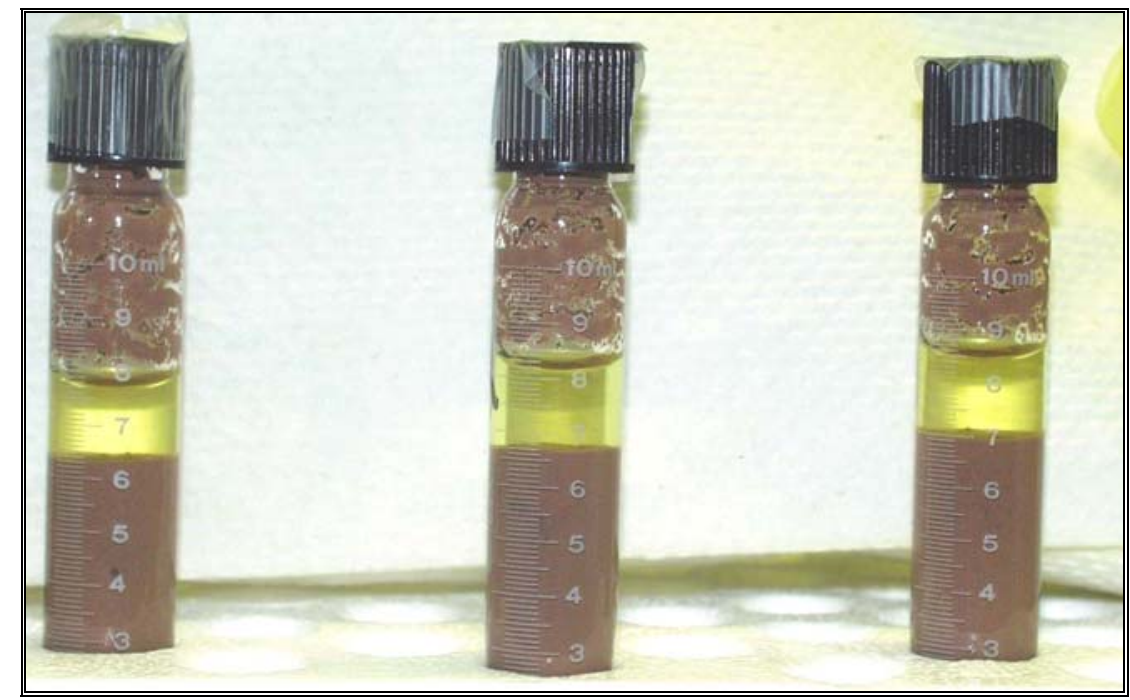

Figure 3-2. Settling of LAW AZ-102 1.3M Na Melter Feed

The settled slurry was then centrifuged at approximately one thousand times the force of gravity for 60 minutes. The total volume after centrifuging $\left(\mathrm{V}_{\mathrm{B}}\right)$ and the solids volume after centrifuging $\left(V_{C S}\right)$ were recorded. The bulk density $\left(\rho_{B}=M_{B} / V_{B}\right)$, vol $\%$ settled solids $\left(\mathrm{P}_{\mathrm{VSS}}=\mathrm{V}_{\mathrm{SS}} / \mathrm{V}_{\mathrm{B}} \times 100 \%\right)$ and vol\% centrifuged solids $\left(\mathrm{P}_{\mathrm{VCS}}=\mathrm{V}_{\mathrm{CS}} / \mathrm{V}_{\mathrm{B}} \times 100 \%\right)$ were then calculated. The issue concerning the reading of the meniscus will impact the calculated results.

The transparent (yellow) supernatant was then transferred from the centrifuged cone to a graduated cylinder. The mass $\left(\mathrm{M}_{\mathrm{S}}=\mathrm{M}_{\mathrm{VL}}\right.$ in this case $)$ and volume $\left(\mathrm{V}_{\mathrm{S}}\right)$ of the supernatant and the mass $\left(\mathrm{M}_{\mathrm{CS}}\right)$ of centrifuged solids were recorded. The density of the supernatant $\left(\rho_{\mathrm{S}}=\mathrm{M}_{\mathrm{S}} / \mathrm{V}_{\mathrm{S}}\right)$, the density of centrifuged solids $\left(\rho_{\mathrm{CS}}=\mathrm{M}_{\mathrm{CS}} / \mathrm{V}_{\mathrm{CS}}\right)$, the $\mathrm{wt} \%$ centrifuged solids $\left(P_{M C S}=M_{C S} / M_{B} \times 100 \%\right)$, the mass of settled solids $\left(M_{S S}=M_{B}-\rho_{S} \times\left(V_{S B}-V_{S S}\right)\right)$, density of settled solids $\left(\rho_{\mathrm{SS}}=\mathrm{M}_{\mathrm{SS}} / \mathrm{V}_{\mathrm{SS}}\right)$ and $\mathrm{wt} \%$ of settled solids $\left(\mathrm{P}_{\mathrm{SS}}=\mathrm{M}_{\mathrm{SS}} / \mathrm{M}_{\mathrm{B}} \times 100 \%\right)$ were then calculated. Variables that could potentially impact these results are:

- Air entrainment. Air could potentially be released during centrifuging. Differences in the final volume between the settling and centrifuged total volume would indicate that such a condition exists. It is also possible that the bubbles would not be released by centrifuging. Correction to the data set requires making assumptions that could bias the results. Correction to this data set will not be performed because the total volumes before/after centrifuging are the same and air entrainment did not seem to be an issue for the LAW AZ-102 melter feeds processed. These slurries were very thin.

- The volume of supernatant transferred from the cone to the graduated cylinder is not $100 \%$ (i.e. not all the free standing supernatant was transferred). This would bias the wt $\%$ of undissolved solids high. The opposite would be true if insoluble solids were transferred for supernatant analysis. 
- Volume of supernatant, as read on the graduated cylinder, could bias the density result high or low. This would impact the settled solids results.

The graduated cylinder containing the supernatant and the centrifuged cone containing the centrifuged solids were then placed overnight into a Thermolyne Model 19200 drying oven at $90^{\circ} \mathrm{C}$ The oven temperature was then increased to $105^{\circ} \mathrm{C}$ and the sample was maintained in the oven until the dried weights stabilized (approximately 2 days). The mass of the dried supernatant solids $\left(\mathrm{M}_{\mathrm{DCL}}\right)$ and mass of the dried centrifuged solids $\left(\mathrm{M}_{\mathrm{DCS}}\right)$ were recorded. Assuming that the mass lost is only water, the $\mathrm{wt} \%$ soluble solids in the supernatant $\left(\mathrm{P}_{\mathrm{SSS}}=\mathrm{M}_{\mathrm{DCL}} / \mathrm{M}_{\mathrm{VL}} \times 100 \%\right)$, wt $\%$ total dried solids (Equation 3-3), wt. \% oven dried solids $\left(\mathrm{P}_{\mathrm{ODS}}=\mathrm{M}_{\mathrm{DCS}} / \mathrm{M}_{\mathrm{CS}} \times 100 \%\right)$ and $\mathrm{wt} \%$ UDS (Equation 3-4) were then calculated. Variables that could potentially impact these results are:

- Volatiles (organics) lost during the oven drying process. Organics would be lost in both the supernatant and centrifuged solids and would result in a lower solids measurement.

- Formation of a hard solid surface over the top of the samples during the evaporation process, which does not allow for the releasing of water (observed with high salt solutions and melter feeds). This condition would yield higher solids measurements. One way to prevent this would be to increase the surface area of the sample.

Generally, these methods are not designed for a production plant and are not recommended for implementation at WTP. The DWPF uses microwave ovens to obtain solids analysis. Additionally, infrared red (heating element) drying ovens have also been tested on WTP slurries and provide equally as reliable results as those obtained using the analysis method applied during this study.

Equation 3-3

$$
P_{M T S}=\left[\frac{P S S S}{100 \%} \cdot \frac{M_{S}}{M_{B}}+\frac{M_{D C S}}{M_{B}}\right] \times 100 \%
$$

Equation 3-4

$$
P_{M U S}=\left[1-\frac{1-\frac{M_{D C L}}{M_{C S}}}{1-\frac{M_{D C L}}{M_{V L}}}\right] \times \frac{M_{C S}}{M_{B}} \times 100 \%
$$


A homogenized sample of the slurry was also transferred to a $50-\mathrm{mL}$ pre-fired high-purity alumina crucible (Coors Tek, Golden, CO). The mass of the sample transferred was recorded $\left(\mathrm{M}_{\mathrm{WCS}}\right)$ and the crucible placed overnight into an oven at $90^{\circ} \mathrm{C}$. The oven temperature was increased to $105^{\circ} \mathrm{C}$ and the sample was maintained in the oven until the dried weight stabilized (about 1 day). The oven dried mass $\left(\mathrm{M}_{\mathrm{OSC}}\right)$ was recorded and the $\mathrm{wt} \%$ dried sample $\left(\mathrm{P}_{\mathrm{MDS}}=\mathrm{M}_{\mathrm{OSC}} / \mathrm{M}_{\mathrm{WCS}} * 100 \%\right)$ calculated. The sample was then placed into a Thermolyne Model 1400 resistance-heated furnace at room temperature, the temperature was raised $\left(200^{\circ} \mathrm{C} / \mathrm{hr}\right)$ to $1050^{\circ} \mathrm{C}$ and maintained at that temperature for 1 hour. The sample was then allowed to cool in the furnace. The weight of the oven fired sample $\left(\mathrm{M}_{\mathrm{FSC}}\right)$ was recorded and the $\mathrm{wt} \%$ total oxides $\left(\mathrm{P}_{\mathrm{MOX}}=\mathrm{M}_{\mathrm{OSC}} / \mathrm{M}_{\mathrm{WCS}} * 100 \%\right)$ calculated. The $\mathrm{wt} \%$ UDS (Equation 3-5), was then calculated using the method employed by SRTC using the wt $\%$ Total Solids (TS) determined by the crucible method and the wt $\%$ soluble solids determined in the supernatant (as calculated above). The same issues as described in section 3.4.1.2 above could also impact the $\mathrm{wt} \%$ dried solids in the sample. Impacts to the $\mathrm{wt} \%$ total oxides could also occur due to volatilization of specific oxides, resulting in a lower wt $\%$.

Equation 3-5 $\quad P_{M U S, S R T C}=\left[\frac{P_{M D S}-P_{S S S}}{100-P_{S S S}}\right] \times 100 \%$

The standard deviations of the measured and calculated values are reported. Calculations, to take into consideration errors with the mass and volume measurements, were not included.

Table 3-10 lists the results for the physical properties of the LAW AZ-102 1.0M Na and $1.3 \mathrm{M} \mathrm{Na}$ melter feeds. Results from the 3 days and 7 days of continuous mixing of the LAW AZ-102 1.0M Na melter feed show little physical difference between the two. The results clearly indicate that any soluble solids from the GFCs that were added had dissolved into the supernatant within the first 3 days of mixing, since there was little difference in the density and soluble solids in the supernatant between the 3 and 7 day measurements.

The total solids from the graduated cone/cylinder method and the crucible method are in agreement. This indicates that there was not a drying issue related to the cone/cylinder in the cone/cylinder method. The wt $\%$ UDS between the SRTC method and WTP project procedure are also in agreement and would have been exact if the same wt $\%$ total solids and wt $\%$ UDS data were used. 
WSRC-TR-2003-00390, REVISION 0

SRT-RPP-2003-00185, REVISION 0

Table 3-10. Physical Properties of LAW AZ-102 1.0M Na and 1.3M Na Melter Feed

\begin{tabular}{|c|c|c|c|c|c|c|c|c|}
\hline \multirow{3}{*}{\multicolumn{2}{|c|}{ Description }} & \multirow[b]{3}{*}{ Units } & \multirow{2}{*}{\multicolumn{2}{|c|}{ 1.0M Na 3-day }} & & & & \\
\hline & & & & & \multicolumn{2}{|c|}{ 1.0M Na 7-day } & \multicolumn{2}{|c|}{ 1.3M Na 1-day } \\
\hline & & & Average & STD & Average & STD & Average & STD \\
\hline \multirow{12}{*}{ 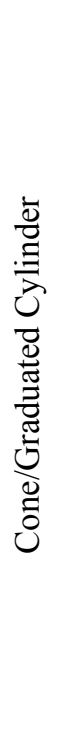 } & Bulk Density - $\rho_{B}$ & $\mathrm{~g} / \mathrm{mL}$ & $1.55^{*}$ & 0.00 & 1.53 & 0.00 & 1.67 & 0.02 \\
\hline & Vol \% Settled Solids - $\mathrm{P}_{\mathrm{VSS}}$ & $\%$ & $69.00^{*}$ & 0.46 & 67.39 & 0.00 & 78.65 & 0.82 \\
\hline & Density of Centrifuged Solids - $\rho_{\mathrm{CS}}$ & $\mathrm{g} / \mathrm{mL}$ & $1.86^{*}$ & 0.01 & 1.89 & 0.01 & 1.90 & 0.01 \\
\hline & Vol \% Centrifuged Solids - $\mathrm{P}_{\mathrm{VCS}}$ & $\%$ & $61.12^{*}$ & 0.46 & 59.42 & 0.00 & 72.40 & 0.62 \\
\hline & Wt. \% Centrifuged Solids - $\mathrm{P}_{\mathrm{MCS}}$ & $\%$ & $73.37^{*}$ & 0.05 & 73.21 & 0.35 & 82.67 & 0.14 \\
\hline & Supernatant Liquid Density - $\rho_{S}$ & $\mathrm{~g} / \mathrm{mL}$ & $1.09 *$ & 0.01 & 1.08 & 0.01 & 1.10 & 0.01 \\
\hline & Density of Settled Solids - $\rho_{\mathrm{SS}}$ & $\mathrm{g} / \mathrm{mL}$ & $1.76^{*}$ & 0.01 & 1.75 & 0.01 & 1.82 & 0.02 \\
\hline & Wt. \% Settled Solids - $\mathrm{P}_{\mathrm{MSS}}$ & $\%$ & $78.26^{*}$ & 0.11 & 77.12 & 0.19 & 85.94 & 0.77 \\
\hline & $\begin{array}{l}\text { Wt } \% \text { soluble solids in supernatant - } \\
\text { P }_{\text {SSS }}\end{array}$ & $\%$ & $8.96^{*}$ & 0.11 & 9.46 & 0.78 & 9.68 & 0.40 \\
\hline & Wt. \% Total Solids - $\mathrm{P}_{\mathrm{MTS}}$ & $\%$ & $53.22 *$ & 0.05 & 53.41 & 0.34 & 59.61 & 0.11 \\
\hline & Wt. \% Oven Dried Solids - $\mathrm{P}_{\mathrm{ODS}}$ & $\%$ & $69.25^{*}$ & 0.02 & 69.46 & 0.06 & 70.06 & 0.12 \\
\hline & Wt. \% UDS - $\mathrm{P}_{\mathrm{MUS}}$ & $\%$ & $48.59^{*}$ & 0.01 & 48.52 & 0.16 & 55.26 & 0.10 \\
\hline \multirow{3}{*}{ ** } & $\mathrm{Wt} \%$ dried total sample - $\mathrm{P}_{\mathrm{MDS}}$ & $\%$ & 53.89 & 0.42 & 53.49 & 0.56 & 59.90 & 0.07 \\
\hline & $\mathrm{Wt} \%$ total oxides $\mathrm{P}_{\mathrm{MOX}}$ & $\%$ & 48.66 & 0.41 & 48.28 & 0.35 & 54.31 & 0.15 \\
\hline & Wt. \% UDS P $\mathrm{P}_{\text {MUS-SRTC }}$ & $\%$ & $49.15^{*}$ & 0.79 & 48.62 & 0.94 & 55.60 & 0.21 \\
\hline
\end{tabular}

*Average of two results. One melter feed sample overflowed during drying.

** Crucible results

\subsubsection{Settling Results of LAW AZ-102 Melter Feed}

Settling tests were performed on the both LAW AZ-102 melter feeds as described in the project Guidelines method [Ref. 1]. First, the slurry sample was placed into a graduated centrifuging cone that was used for the physical property determinations, after completion of the settling test. The tube was shaken to homogenize the slurry sample and then it was allowed to settle for at least three days. The three samples of slurry were homogenized within 10 seconds of each other and placed into a centrifuge tube holder. The time after homogenization was recorded and volume measurements were taken of the interface layer, which is the layer between the clear supernatant and settling slurry at specified time intervals [Ref. 1]. Figure 3-2 shows the graduated centrifuge tubes used for the settling test. The recorded settling data was normalized and the average normalized interface volume data for the first 60 minutes is shown in Figure 3-3. After 30 minutes, there is little change in the normalized interface volume for all the LAW AZ-102 melter feeds as shown in Table 3-11. The LAW AZ-102 1.0M Na melter feed 3 day and 7 day results are very similar, but the 3 -day results indicate that it takes a little longer for the solids to settle. 
The settling data has not been corrected for wall or hindered settling effects. This data is limited only to decanting operations or to determine the amount of settled solids. The data can also be used to determine if rheological measurements using standardized rotational bench scale rheometers can be utilized to measure the rheological properties of the sample based on how quickly the interface is produced relative to the time it takes to perform flow curve measurement. There are established standards for settling tests that are used for decanting, but the measuring vessel and sample size are much larger than what is used here. The larger vessel size is used to minimize wall effects.

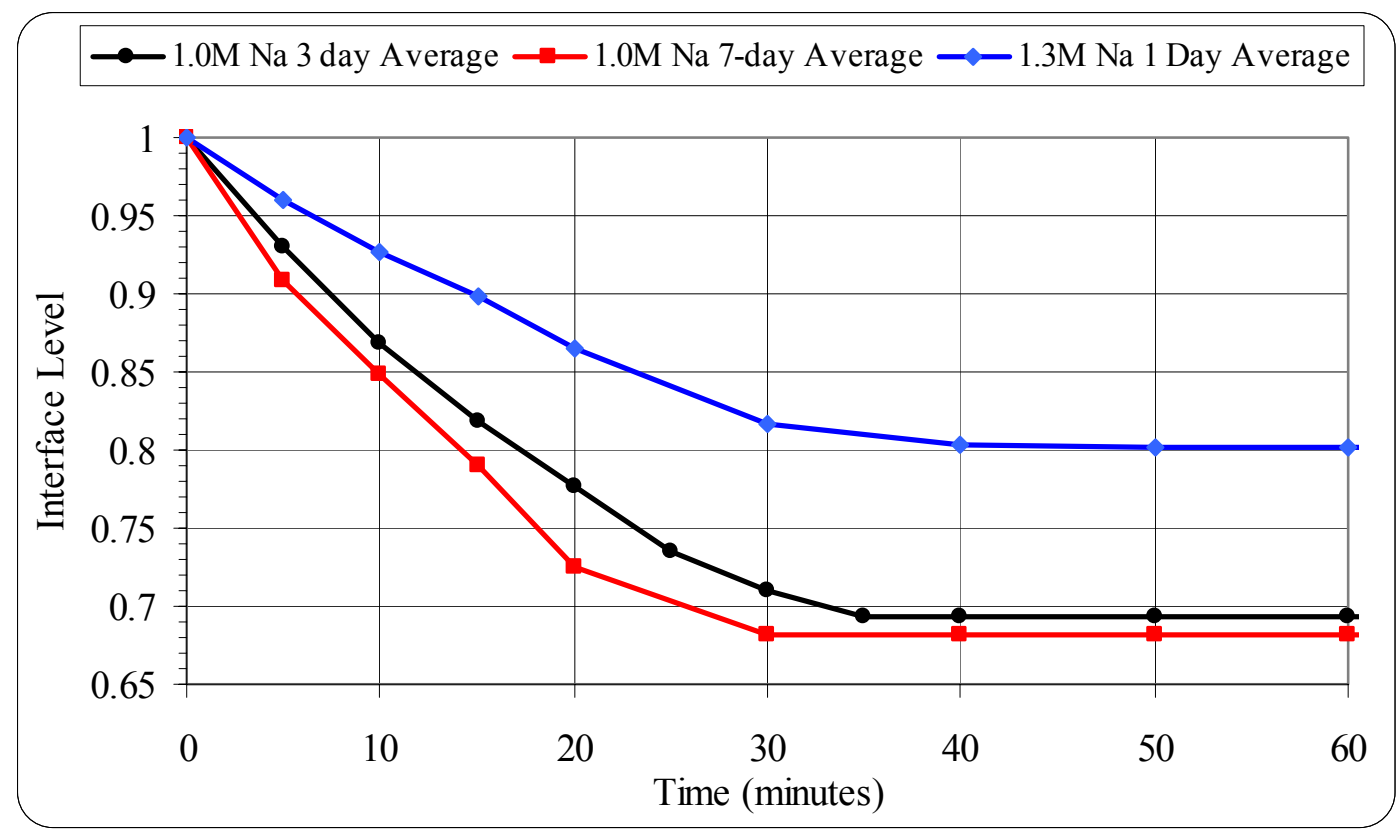

Figure 3-3. Normalized Settling Curves for LAW AZ-102 Melter Feed 
WSRC-TR-2003-00390, REVISION 0

SRT-RPP-2003-00185, REVISION 0

Table 3-11. Normalized Interface Volume for LAW AZ-102 Melter Feed

\begin{tabular}{|c|c|c|c|c|c|}
\hline \multicolumn{2}{|c|}{$1.0 \mathrm{M} \mathrm{Na}-3$ days mixing } & \multicolumn{2}{|c|}{$1.0 \mathrm{M} \mathrm{Na}-7$ days mixing } & \multicolumn{2}{|c|}{$1.3 \mathrm{M} \mathrm{Na}-1$ day Mixing } \\
\hline Time (min) & $\begin{array}{c}\text { Normalized } \\
\text { Interface } \\
\text { Volume }\end{array}$ & Time (min) & $\begin{array}{c}\text { Normalized } \\
\text { Interface } \\
\text { Volume }\end{array}$ & Time (min) & $\begin{array}{c}\text { Normalized } \\
\text { Interface } \\
\text { Volume }\end{array}$ \\
\hline 0 & 1 & 0 & 1.000 & 0 & 1.000 \\
\hline 5 & 0.930 & 5 & 0.908 & 5 & 0.960 \\
\hline 10 & 0.869 & 10 & 0.848 & 10 & 0.927 \\
\hline 15 & 0.818 & 15 & 0.790 & 15 & 0.899 \\
\hline 20 & 0.777 & 20 & 0.725 & 20 & 0.864 \\
\hline 25 & 0.735 & 30 & 0.681 & 30 & 0.816 \\
\hline 30 & 0.710 & 40 & 0.681 & 40 & 0.804 \\
\hline 35 & 0.694 & 50 & 0.681 & 50 & 0.802 \\
\hline 40 & 0.694 & 60 & 0.681 & 60 & 0.802 \\
\hline 50 & 0.694 & 1440 & 0.676 & 120 & 0.802 \\
\hline 60 & 0.694 & 1920 & 0.676 & 180 & 0.802 \\
\hline 240 & 0.694 & 2880 & 0.676 & 360 & 0.802 \\
\hline 360 & 0.694 & 4320 & 0.676 & 1440 & 0.792 \\
\hline 1440 & 0.694 & N/A & N/A & 2880 & 0.792 \\
\hline 4320 & 0.694 & N/A & N/A & 4320 & 0.788 \\
\hline
\end{tabular}

\section{5 pH MEASUREMENT}

The pHs of the LAW AZ-102 pretreated waste and melter feeds was measured using a Fisher Scientific 'Accumet AB15' pH meter fitted with a Fisher Scientific gel-filled, epoxy body combination electrode with $\mathrm{Ag} / \mathrm{Ag} / \mathrm{Cl}$ reference $\mathrm{pH}$ probe at ambient conditions. The results are shown in Table 3-12. The functionality of the $\mathrm{pH}$ meter and probe were confirmed by measuring three different $\mathrm{pH}$ buffers at $\mathrm{pHs}$ of 4,7 , and 10 before sample measurements were performed. These Fisher Scientific $\mathrm{pH}$ buffers are certified to within $+/-0.02 \mathrm{pH}$ units and were used within the designated expiration date listed on each buffer. The $\mathrm{pH}$ of the pretreated feeds decreased when GFCs were added. This is due to the addition of acidic species in the GFCs, such as boric acid. There is not much change in the $\mathrm{pH}$ of the LAW AZ-102 1.0M Na melter feed after 3 days and 7 days of mixing.

The measured $\mathrm{pH}$ values were outside the calibrated range of the $\mathrm{pH}$ instrument for the pretreated feeds. The error in the measurement is unknown, since no sample exists where $\mathrm{pH}$ paper can be used to verify the measurement. 
WSRC-TR-2003-00390, REVISION 0

SRT-RPP-2003-00185, REVISION 0

Table 3-12. pH of the LAW AZ-102 Pretreated Wastes and Melter Feeds

\begin{tabular}{|c|c|c|c|}
\hline \multicolumn{2}{|c|}{ Pretreated Waste } & \multicolumn{2}{|c|}{ Melter Feed } \\
\hline Na Molarity & $\mathrm{pH}$ & Na Molarity & $\mathrm{pH}$ \\
\hline 1.0 & 12.01 & $\mathbf{1 . 0}-3$ days of mixing & 9.04 \\
\hline 1.3 & 12.15 & $\mathbf{1 . 0}-7$ days of mixing & 9.22 \\
\hline N/A & N/A & $\mathbf{1 . 3}-1$ day of mixing & 8.72 \\
\hline
\end{tabular}

\subsection{RHEOLOGICAL MEASUREMENTS}

Rheological properties of the LAW AZ-102 pretreated wastes and melter feeds were analyzed per the project Guidelines methods [Ref. 1]. The rheological properties of the pretreated waste and melter feeds were analyzed by measuring the shear stress-shear rate flow curves. The melter feeds settled solids shear strength was determined using the vane technique.

\subsubsection{Instrumentation}

The Haake M5/RV20 rheometer was used for all rheological measurements performed in this task. The M5 measuring head specifications are shown in Table 3-13.

Table 3-13. M5 Measuring Head Specifications

\begin{tabular}{|c|c|c|}
\hline Specification & Units & Value \\
\hline Maximum Torque & N-cm & 4.9 \\
\hline Minimum Torque (recommended) & N-cm & 0.049 \\
\hline Deviation in Torque Measurement & \% of maximum & $+/-0.5$ \\
\hline Maximum Speed & RPM & 500 \\
\hline Minimum Speed & RPM & 0.05 \\
\hline Error in Speed Measurement & \% of reading & $+/-0.5$ \\
\hline
\end{tabular}




\subsubsection{Flow Curve Measurements Using Concentric Geometry}

Flow curve measurements were obtained using concentric (MV1) and double concentric (NV) cylindrical rotors. Their designs are shown in Table 3-14. The MV1 or NV rotor was initially installed onto the M5 measuring head. A sample was then placed into the appropriate cup (cup dimension provided in Table 3-14), given which rotor is being utilized, and raised into a temperature- controlled cup holder, which controlled the temperature at $25^{\circ} \mathrm{C}$. The RV20 rheometer controls the rate at which the M5 measuring head spins the rotor and measures both the rotational speed and the torque (the resistance to shear). The shear stress at the wall of the rotating rotor is then calculated (internally by the Haake software) based on the product of the measured torque and geometry (A-factor) of the rotor. The shear rate of the rotating rotor is calculated as the product of the measured speed and geometry (M-factor, assumes fluid is Newtonian) of the rotor. The A-factor, M-factor, shear rate range and the ramp up time, hold time at maximum shear rate, and ramp down time are provided in Table 3-14. The NV rotor was used to measure the pretreated feed and supernatant. The MV1 rotor was used to measure the melter feed.

Table 3-14. NV and MV1 Rotor Specifications and Ramp Rates

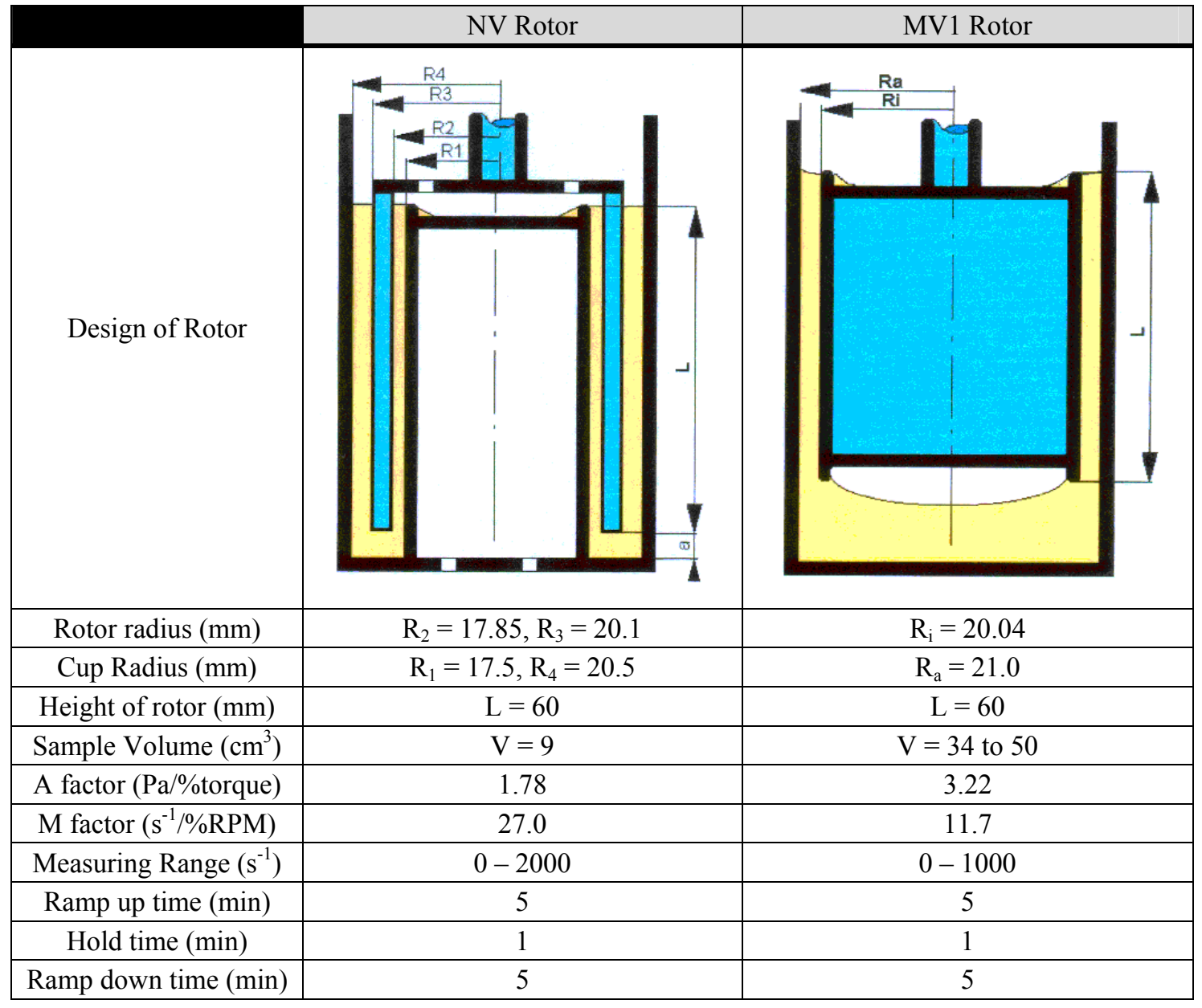


Prior to performing any flow curve measurement, the rotor and cup are inspected for visual damage that could potentially impact the flow measurement. National Institute of Standards and Technology (NIST) traceable Newtonian oil standards were used to verify the operability of the M5 head at a measurement temperature of $25^{\circ} \mathrm{C}$. The viscosities of the NIST traceable Newtonian oil standards at $25^{\circ} \mathrm{C}$ are shown in Table 3-15. The resulting flow curves were analyzed as a Newtonian fluid and the calculated viscosity was compared to the NIST traceable Newtonian oil standard. The rheometer was considered operable if the calculated viscosity was within $\pm 10 \%$ of the NIST traceable Newtonian oil standard viscosity as stated in Table 3-15. The measuring range of the NV/M5 as specified by Haake shows a lower limit around approximately $5 \mathrm{cP}$ at very high shear rates $\left(+2000 \mathrm{sec}^{-1}\right)$, but does not provide any error associated with the measurement. Using the uncertainties provided by Haake in the measured torque and speed of the M5 measuring head (Table 3-13), the resulting viscosity, when using the S3 NIST traceable Newtonian oil standard used in this study, may vary as much as $\pm 13.6 \%$ (given a $95 \%$ or $2 \sigma$ confidence [Ref. 6 ] level at a shear rate of $2000 \mathrm{sec}^{-1}$ and assuming the uncertainties provided by Haake in the torque and speed has $2 \sigma$ confidence level), but the rheometer was not considered inoperable. Measurements below $5 \mathrm{cP}$ will have to be used with a higher level of uncertainty and will be based on the actual measurement results.

Table 3-15. Cole-Parmer NIST Traceable Newtonian Oil Standard

\begin{tabular}{|c|c|c|c|c|c|}
\hline \multirow{2}{*}{$\begin{array}{l}\text { Standard } \\
\text { Type }\end{array}$} & \multicolumn{3}{|c|}{ Viscosity $(\mathrm{cP})$ at $25^{\circ} \mathrm{C}$} & \multirow{2}{*}{ Lot Number } & \multirow{2}{*}{$\begin{array}{c}\text { Expiration } \\
\text { Date }\end{array}$} \\
\hline & $-10 \%$ & Reported & $+10 \%$ & & \\
\hline S3 & 2.939 & 3.266 & 3.593 & F102609 & Oct. 10,2004 \\
\hline N35 & 45.44 & 50.49 & 55.54 & F102205 & Nov. 27,2004 \\
\hline DI $\mathrm{H}_{2} \mathrm{O}$ & 0.801 & 0.89011 & 0.979 & N/A & N/A \\
\hline
\end{tabular}

The Newtonian results of the NIST traceable Newtonian oil standard are shown in Table 3-16. The NV rotor was run with the S3 oil standard, with 2 of the 3 measurements being within $10 \%$ of the standard. Table 3-16 shows the result for DI water using the NV rotor, resulting in a slightly higher viscosity than predicted. The results obtained in this study using the NV rotor for fluids with low viscosity (less than $3.266 \mathrm{cP}$ ) had a $16 \%$ error in the measured viscosity. The NV rotor is not recommended for measuring fluids that are less viscous than water, since there is no reference to compare the results. The results of using such low viscosity fluids will not impact the normal operation of the M5 measuring head. Another issue when characterizing low viscosity fluids is the inertia effect of the rotor, which becomes much more predominate for low viscosity fluids as compared to more viscous fluids. 
WSRC-TR-2003-00390, REVISION 0

SRT-RPP-2003-00185, REVISION 0

Table 3-16. M5 Operability Checks Using NIST Traceable Viscosity Oil Standards

\begin{tabular}{|c|c|c|c|c|}
\hline Rotor & NIST Standard & Run Date & $\begin{array}{c}\text { Measured } \\
\text { Viscosity (cP) }\end{array}$ & $\begin{array}{c}\text { Viscosity within } \\
+/-10 \%\end{array}$ \\
\hline NV & S3 & $6 / 18 / 03$ & 3.08 & Yes $(-5.7 \%)$ \\
\hline MV1 & N35 & $6 / 25 / 03$ & 53.2 & Yes $(5.4 \%)$ \\
\hline NV & S3 & $6 / 27 / 03$ & 3.15 & Yes $(-3.4 \%)$ \\
\hline MV1 & N35 & $7 / 3 / 03$ & 52.8 & Yes $(-4.6 \%)$ \\
\hline MV1 & N35 & $7 / 7 / 03$ & 52.6 & Yes $(-4.2 \%)$ \\
\hline NV & S3 & $7 / 9 / 03$ & 2.80 & No $(-14.3 \%)$ \\
\hline NV & DI water & $6 / 18 / 03$ & 1.03 & No $(+15.7 \%)$ \\
\hline
\end{tabular}

\subsubsection{Yield Stress Measurement Using Vane Geometry}

Vanes have been used [Ref. 7 through 20] to measure the yield stress of non-Newtonian fluids as is shown in Figure 3-4. The vane is inserted into the fluid and rotated at a very slow speed. The surface area used to determine the shear stress is the surface area produced by the vane, in other words, a cylinder. It has been shown that this is a good assumption [Ref. 8, 9, 12, and 13] for determining the stress of the fluid as the vane rotates through it. The derived equation ( ) assumes the stress is constant on all surfaces. The shearing due to the immersed section of the vane shaft, stress contribution of the immersed section of the shaft, and the wall effects are negligible by meeting the criteria as shown in Figure 3-4.

\section{Equation 3-6}

$$
\tau_{\text {vane }}=\frac{\Gamma}{\frac{\pi \cdot D^{3}}{2}\left(\frac{H}{D}+\frac{1}{3}\right)}=A \cdot \Gamma
$$

where $\Gamma=$ measured torque $(\mathrm{N}-\mathrm{m}$ or $\%$ torque $)$

$\mathrm{D}=$ diameter of vane $(\mathrm{m})$

$\mathrm{H}=$ height of vane $(\mathrm{m})$

$\mathrm{A}=$ geometric constant $\left(\mathrm{m}^{3}\right.$ or $\left.\mathrm{Pa} / \% \Gamma\right)$

$\tau_{\text {vane }}=$ shear stress $(\mathrm{Pa})$ 


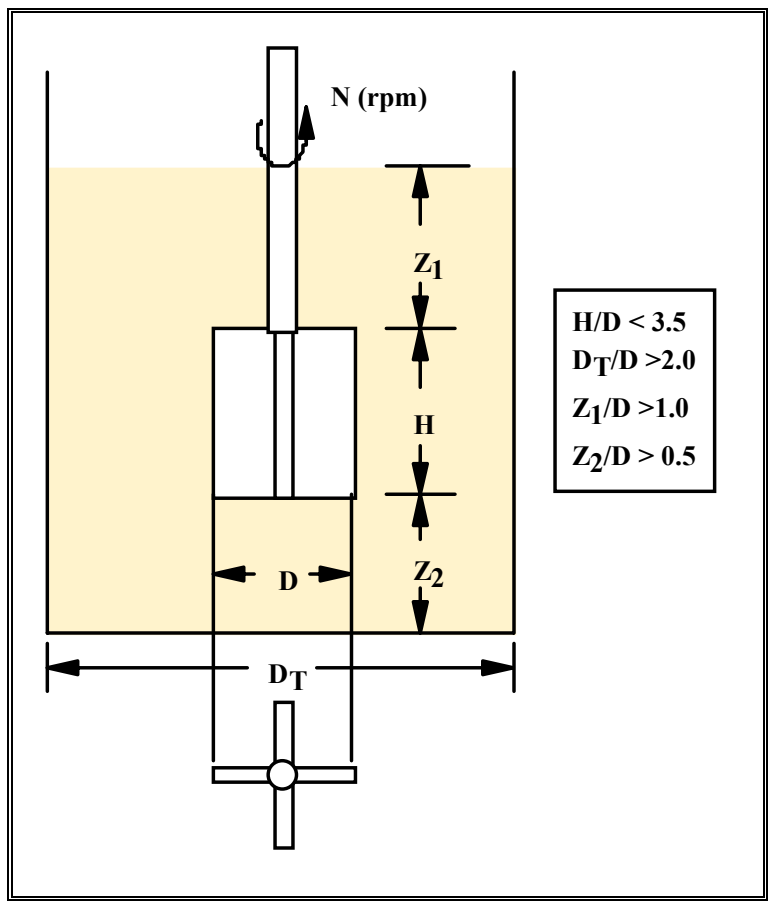

Figure 3-4. Vane Geometric Requirements

A typical stress versus time (or displacement) curve is shown in Figure 3-5. The initial response for a non-Newtonian fluid having a yield stress is typically linear and this slope is called the Hookean elastic modulus $(\mathrm{G})$. The point of departure from this linear region is called the static yield stress [Ref. 7] when the fluid starts to transition from a fully elastic to viscoelastic behavior. At the maximum stress, the behavior of the material transitions between viscoelastic and fully viscous and is called the yield stress (known also as the dynamic yield stress).

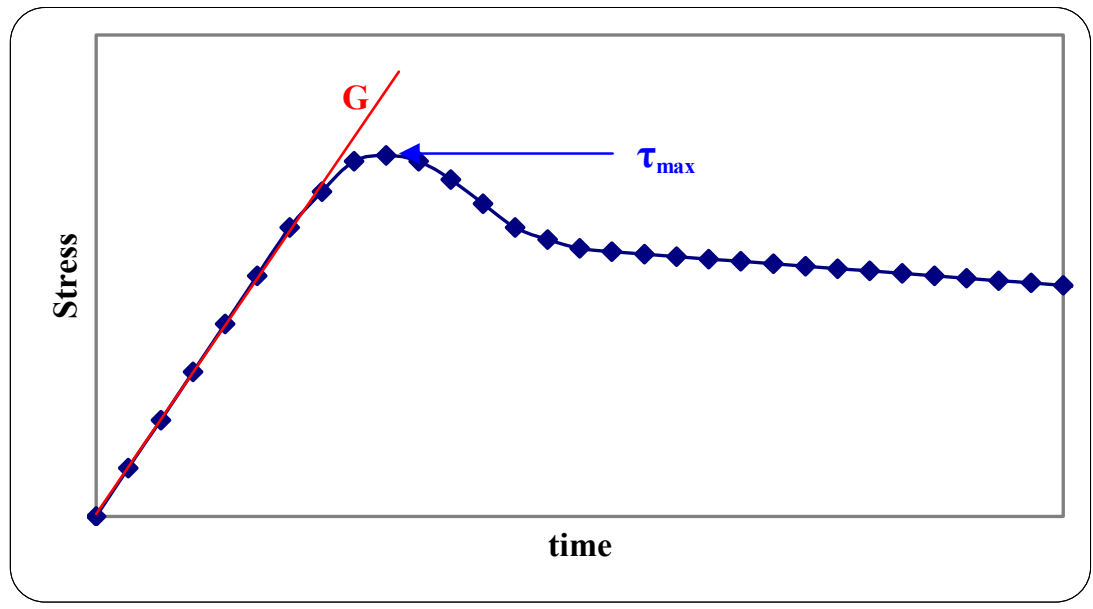

Figure 3-5. Typical Torque - Time/Displacement Curve 
The vane dimensions used in this task were $\mathrm{D}=\mathrm{H}=16 \mathrm{~mm}$. The A factor for the M5 measuring head was calculated and used in the RV20 to calculate the stress from the measured torque, given the measured \%torque. The A factor used is shown in Equation 3-7.

Equation 3-7 $A=\frac{A^{\prime} \cdot \Gamma_{\max }}{100 \%}=\frac{2}{\pi \cdot(0.016 \mathrm{~m})^{3} \cdot\left(\left(\frac{16}{16}\right)+\frac{1}{3}\right)} \cdot \frac{4.9 \mathrm{~N} \cdot \mathrm{cm}}{100 \% \Gamma} \cdot \frac{\mathrm{m}}{100 \mathrm{~cm}}=57.12 \frac{\mathrm{Pa}}{\% \Gamma}$

For the vane measurements, the $\mathrm{M}$ factor was set at $1.0 \mathrm{sec}^{-1} / \% \mathrm{RPM}$. Going through the same exercise as that shown in Equation 3-7, for a rotational speed of $0.3 \mathrm{RPM}$, the controlled shear rate was $0.06 \mathrm{sec}^{-1}$ and used in the RV20. The rotational speed was also visually verified at approximately 0.3 revolutions per minute (RPM). This rotational speed is specified in project approved Guidelines [Ref. 1]. The sample cup used for vane measurements had an inside diameter of $40 \mathrm{~mm}$. The samples were allowed to settle for at least 2 days prior to performing the yield stress measurement. There is no NIST standard available in which the vane can be used to verify the operability of a rheometer. The M5/RV20 rheometer is verified operational via the functional check using a NIST Newtonian oil standard, using concentric geometry. The M5 head has an error of $0.5 \%$ of full torque (Table 3-13), resulting in an error of $\pm 28.56 \mathrm{~Pa}$ or $\pm 285.6 \mathrm{dynes} / \mathrm{cm}^{2}$ in the measured stress.

The yield stress after settling at various times will be reported as the "settled solids shear strength" which is consistent with WTP terminology.

\subsubsection{LAW AZ-102 Pretreated Waste Rheology Results}

Duplicate flow curves for each LAW AZ-102 pretreated waste were measured at $25^{\circ} \mathrm{C}$. The flow curves are shown in Figure 3-6 for the 1.0M Na pretreated waste and Figure 3-7 for the $1.3 \mathrm{M} \mathrm{Na}$ pretreated waste. The averaged viscosities of the $1.0 \mathrm{M} \mathrm{Na}$ and $1.3 \mathrm{M} \mathrm{Na}$ pretreated wastes are $1.2 \mathrm{cP}$ (or $1.2 \mathrm{mPa}-\mathrm{sec}$ ) and $1.1 \mathrm{cP}$. This indicates that the $1.3 \mathrm{M}$ Na pretreated waste is less viscous than the $1.0 \mathrm{M} \mathrm{Na}$ pretreated waste; but considering only instrument error, the results easily overlap each other. The instrument error, at the maximum shear rate of $2000 \mathrm{sec}^{-1,}$ as measured in this report, is at least $\pm 37 \%$ [Ref. 6 ] given a $95 \%$ confidence level. In either case, the results clearly show that these pretreated wastes are not much different from each other and are very close to the viscosity of water. 


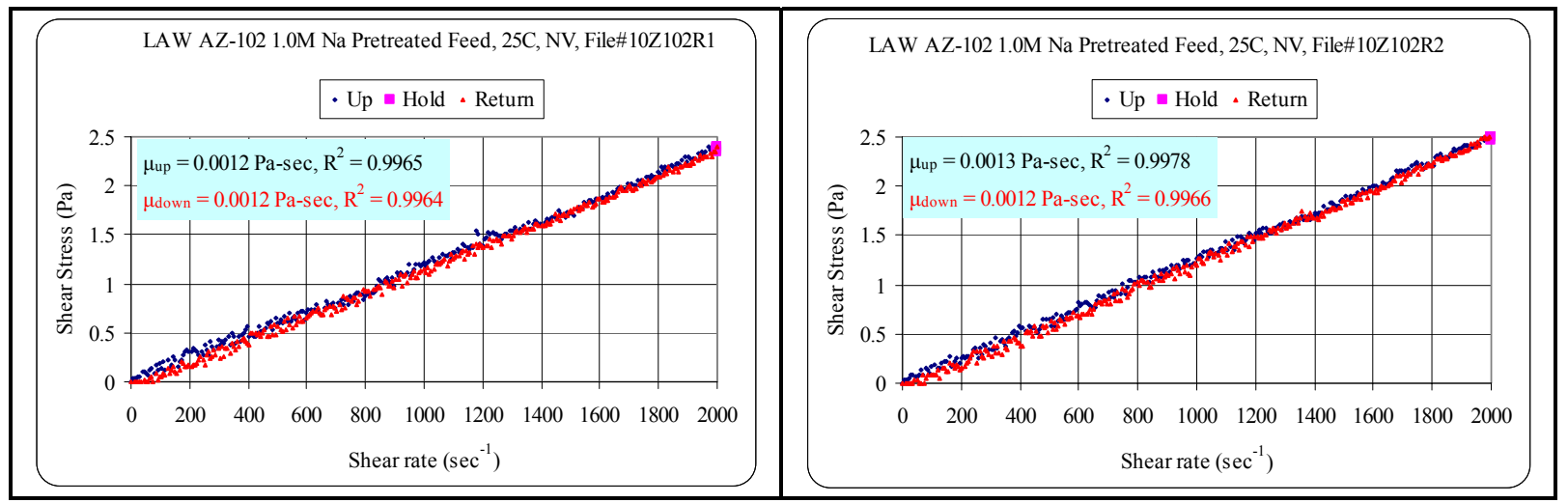

Figure 3-6. LAW AZ-102 1.0M Na Pretreated Waste Flow Curve

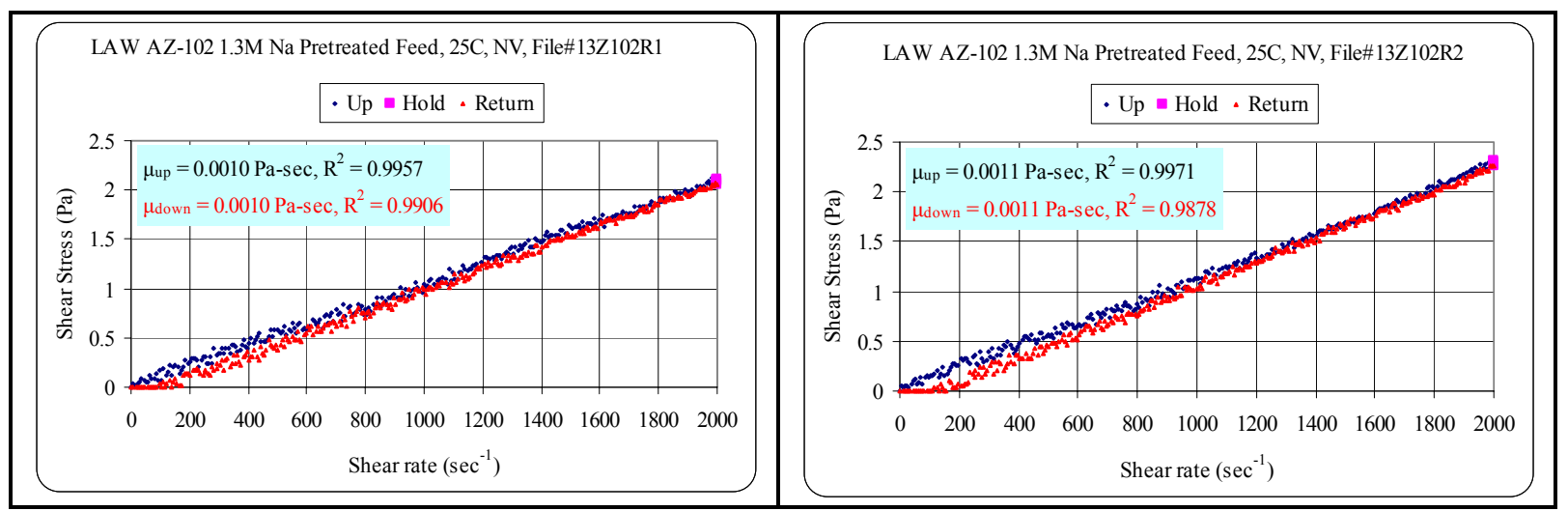

Figure 3-7. LAW AZ-102 1.3M Na Pretreated Waste Flow Curve

\subsubsection{LAW AZ-102 Melter Feed Rheology Results}

Duplicate flow curves of each LAW AZ- 102 melter feed were measured at $25^{\circ} \mathrm{C}$. It was observed that a hard settled layer (thickness never quantified) had developed within 30 minutes after the sample was removed from the agitated mixing vessel in preparation of performing the rheology measurements. Based on the settling curve results (section 3.4.2), the melter feed samples were homogenized, placed into the MV cup, loaded into the cooling/heating jacket, and trimmed. The program started within 30 seconds from the time the sample was loaded into the cup and the flow curves for the 1.0M Na melter feed, after 3 and 7 days of mixing, are shown in Figure 3-8 and Figure 3-9. Both exhibit essentially the same behavior and maximum measured stress. The $1.3 \mathrm{M}$ Na melter feed is shown in Figure 3-10. This feed is more viscous than the $1.0 \mathrm{M}$ Na melter feeds, but it also has the same shape flow curves as that of the $1.0 \mathrm{M} \mathrm{Na}$ melter feeds. The resulting flow curves can not be analyzed, using the rheological models as specified in project approved Guidelines [Ref. 1] or any rheological model, since the results would be meaningless. All the melter feed flow curves were impacted by the settling nature of the melter feed material. An explanation of the behavior of each section of the flow curve is provided in Table 3-17. 
WSRC-TR-2003-00390, REVISION 0

SRT-RPP-2003-00185, REVISION 0
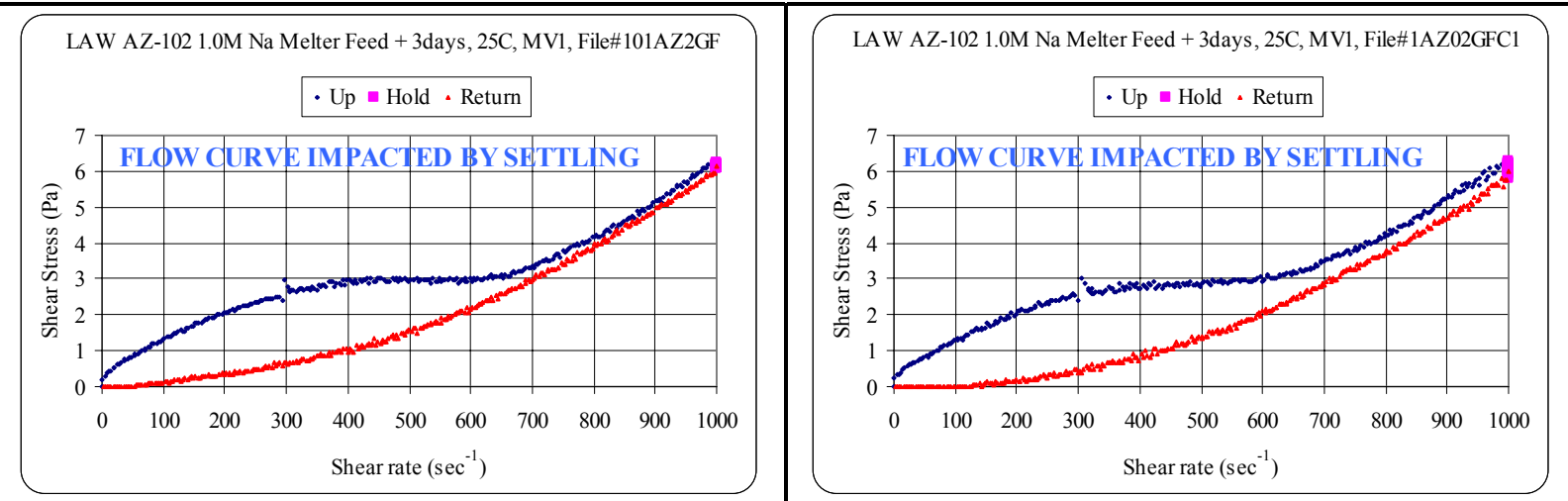

Figure 3-8. LAW AZ-102 1.0M Na Melter Feed, After 3 Days of Mixing
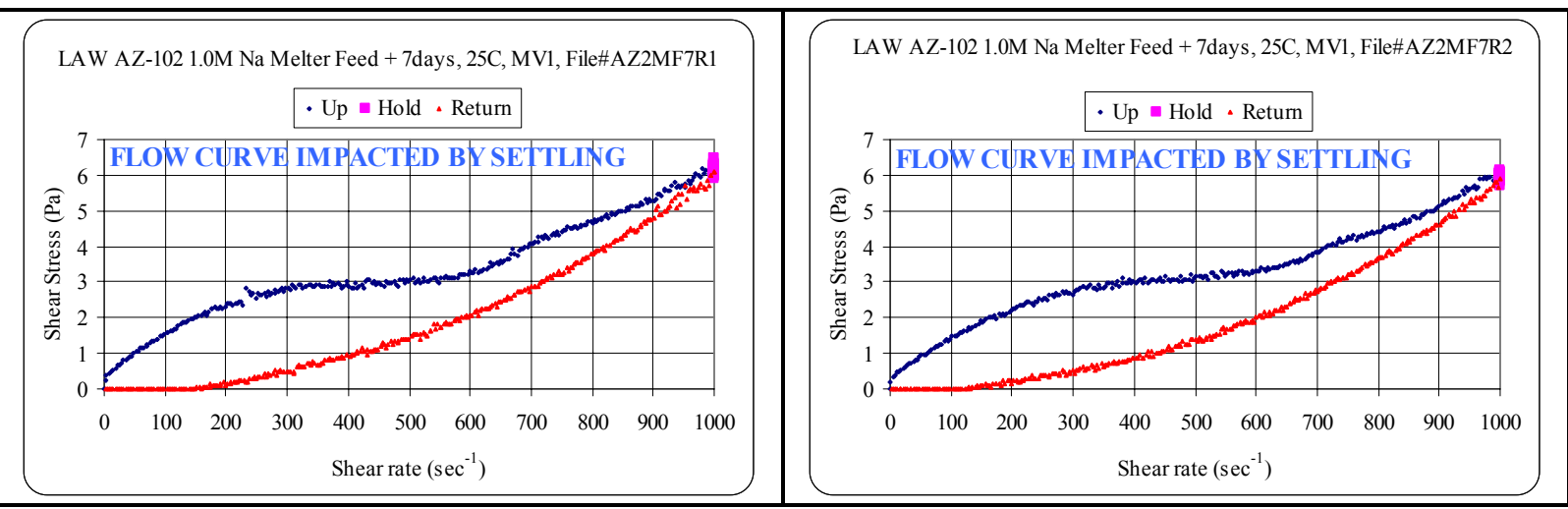

Figure 3-9. LAW AZ-102 1.0M Na Melter Feed, After 7 Days of Mixing

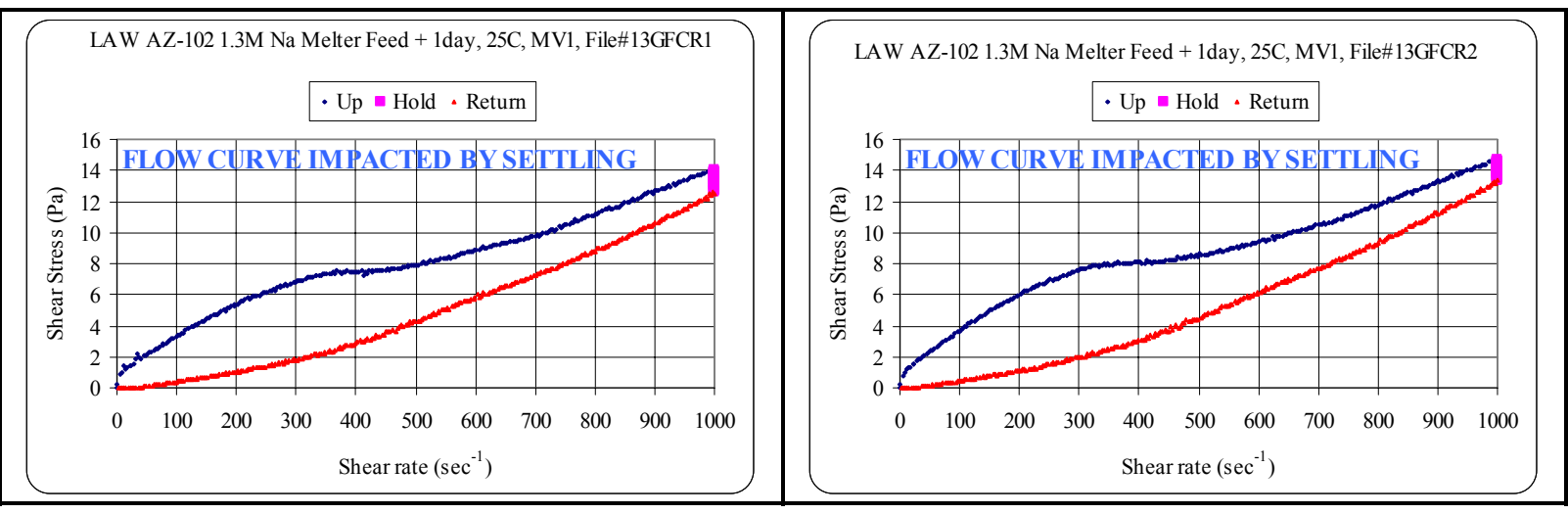

Figure 3-10. LAW AZ-102 1.3M Na Melter Feed, After 1 Day of Mixing 
WSRC-TR-2003-00390, REVISION 0 SRT-RPP-2003-00185, REVISION 0

Table 3-17. Settling Impact on LAW AZ-102 Melter Feed Flow Curves

\begin{tabular}{|c|c|l|}
\hline $\begin{array}{c}\text { Curve } \\
\text { Location }\end{array}$ & $\begin{array}{c}\text { Shear rate range } \\
\left(\mathrm{sec}^{-1}\right)\end{array}$ & \multicolumn{1}{c|}{ Explanation } \\
\hline \multirow{2}{*}{$\begin{array}{c}\text { Up } \\
\text { Section }\end{array}$} & $\begin{array}{c}0-300(1.0 \mathrm{M}) \\
0-325(1.3 \mathrm{M})\end{array}$ & $\begin{array}{l}\text { Curve fit of flow curves would result in a power law index of less than one and } \\
\text { a yield stress. From settling data and from visual observation, both the 1.0 and } \\
1.3 \mathrm{M} \text { Na melter feeds do not have any yield stress. Power law index less than } \\
\text { one due to settling of solids out of shearing gap. }\end{array}$ \\
\cline { 2 - 4 } & $300-625(1.0 \mathrm{M})$ & $\begin{array}{l}\text { Increase in shear rate causes essentially no increase in shear stress, indicating } \\
\text { material is settling through and out of the shearing gap. Or massive slip is } \\
\text { occurring. }\end{array}$ \\
\cline { 2 - 4 } & up to 1000 & $\begin{array}{l}\text { Curves are somewhat shear thickening (n>1). Could be due to the clear } \\
\text { supernatant generated by settling is producing Taylor vortices. }\end{array}$ \\
\hline Hold & 1000 & $\begin{array}{l}\text { Shear stress going down, due to solids settling out of the shearing zone. More } \\
\text { material settling out of the 1.3M as compared to the 1.0M when comparing the } \\
\text { drop in shear stress. }\end{array}$ \\
\hline $\begin{array}{c}\text { Down } \\
\text { Section }\end{array}$ & 1000 to 0 & $\begin{array}{l}\text { If curve fitted, would be shear thickening (n>1). Reduction in shear stress is } \\
\text { most likely due to settling or Taylor Vortices. Other issues could be due to } \\
\text { inertia effects of the rotor slowing down in a thin solution. }\end{array}$ \\
\hline
\end{tabular}

A clear supernatant level developed between the gap at the top of the concentric cylinder and cup was clearly evident within 30 seconds after starting the flow curve measurements.

Because these slurries are not thixotropic (in the rheological sense), a second flow curve was not performed while the settled slurry was in the MV1 geometry. If such a measurement were performed, it would be too difficult to distinguish between the shear stress contribution of the clear supernatant (and potential Taylor vortices that could be generated) and that of the settled solids (with the amount of settled solids concentration unknown). At this time, the settled solids would not be representative of $\mathrm{wt} \%$ solids concentration in the original slurry. Slurries with such behavior must be tested in a slurry test loop to determine the critical velocity at which all the solids are just suspended. The velocity may also be determined for other conditions, such as complete homogeneity in the pipeline.

The slurry used for the flow curves was placed into a settling cup (for the yield stress settled solids shear strength measurements) and allowed to settle for the allotted time (see Table 3-19 for settling times). After the settled solids shear strength was measured, the clear supernatant was analyzed at $25^{\circ} \mathrm{C}$ for rheology using the NV geometry. All the flow curves obtained indicate that the supernatant was Newtonian as fitted from a shear rate range of 0 to $2000 \mathrm{sec}^{-1}$ with the results presented in Table 3-18. The viscosity of the 1.0M Na melter feed supernatant did not change after 3 days and 7 days of mixing. The viscosity of the $1.3 \mathrm{M} \mathrm{Na}$ melter feed supernatant is more viscous than the $1.0 \mathrm{M}$ Na melter feed supernatant. However, considering only instrument error, the results could easily overlap each other. The instrument error, at the maximum shear rate of $2000 \mathrm{sec}^{-1}$, as measured in this report, is at least $\pm 25 \%$ [Ref. 6 ] given a $95 \%$ confidence level. 
Table 3-18. LAW AZ-102 Melter Feed Supernatant Viscosity

\begin{tabular}{|c|c|c|c|c|c|}
\hline Supernatant & Run & File & Fitted Region & $\mathrm{R}^{2}$ & Viscosity (cP) \\
\hline \multirow{5}{*}{$\begin{array}{l}\text { 1.0M Na } \\
+3 \text { Day }\end{array}$} & \multirow{2}{*}{1} & \multirow{2}{*}{ 1AZSUP34.ROT } & Up & 0.9938 & 1.83 \\
\hline & & & Down & 0.9973 & 1.78 \\
\hline & \multirow{2}{*}{2} & \multirow{2}{*}{ 1AZSUP36.ROT } & Up & 0.9968 & 1.82 \\
\hline & & & Down & 0.9978 & 1.81 \\
\hline & \multicolumn{4}{|r|}{ Average } & 1.81 \\
\hline \multirow{5}{*}{$\begin{array}{l}\text { 1.0M Na } \\
+7 \text { Day }\end{array}$} & \multirow{2}{*}{1} & \multirow{2}{*}{ 1AZSUP71.ROT } & $\mathrm{Up}$ & 0.9982 & 1.79 \\
\hline & & & Down & 0.9981 & 1.78 \\
\hline & \multirow{2}{*}{2} & \multirow{2}{*}{ 1AZSUP72.ROT } & Up & 0.9974 & 1.74 \\
\hline & & & Down & 0.9970 & 1.71 \\
\hline & \multicolumn{4}{|r|}{ Average } & 1.76 \\
\hline \multirow{5}{*}{$\begin{array}{l}1.3 \mathrm{M} \mathrm{Na} \\
+7 \mathrm{Day}\end{array}$} & \multirow{2}{*}{1} & 13MFSUP1.ROT & $\mathrm{Up}$ & 0.9987 & 1.97 \\
\hline & & & Down & 0.9989 & 1.98 \\
\hline & \multirow{2}{*}{2} & \multirow{2}{*}{ 13MFSUP2.ROT } & Up & 0.9985 & 1.97 \\
\hline & & & Down & 0.9988 & 1.92 \\
\hline & \multicolumn{4}{|r|}{ Average } & 1.96 \\
\hline
\end{tabular}

\subsubsection{Settled Solids Vane Measurement Results}

Upon completion of the flow curve measurements, the slurry samples in the MV cup were placed into the cup used for the vane measurement and additional slurry was added to provide a sufficient zone of settled solids. The resulting settled solids met the criteria stated in Figure 3-4. The inside diameter of the cup was $40 \mathrm{~mm}$. The total height, settled solids height, the supernatant height, and undisturbed settling time are provided in Table 3-19.

Table 3-19. Settled Solids Height and Times for Vane Measurements

\begin{tabular}{|c|c|c|c|c|}
\hline \multirow{2}{*}{$\begin{array}{c}\text { Settled LAW AZ-102 Melter } \\
\text { Feed Sample Description }\end{array}$} & \multicolumn{3}{|c|}{ Height (mm) } & Settling Time \\
\cline { 2 - 4 } & Total & Settled & Supernatant & (Hrs) \\
\hline 1.0M Na, 3 days of mixing & 77 & 49 & 28 & 72 \\
\hline 1.0M Na, 7 days of mixing & 80 & 53 & 27 & 48 \\
\hline 1.3M Na, 1 day of mixing & 64 & 51 & 13 & 50 \\
\hline
\end{tabular}

For each sample, the vane was inserted $16 \mathrm{~mm}$ down into the settled solids at the center of the cross sectional area of the cup. A second measurement of the 1.0M Na sample, after 7 days of mixing, was made immediately after the initial vane measurement by inserting the vane an additional $13 \mathrm{~mm}$ into the sample (leaving the bottom of the vane about $8 \mathrm{~mm}$ from the bottom of the cup). For this second measurement, the sample did not meet the bottom clearance criteria stated in Figure 3-4 and was partially extended into the sheared volume of the previous sample. The vane results are shown in Figure 3-11. After 7 days of mixing, the 1.0M Na sample showed a much greater shear strength measurement than the after 3 days of mixing measurement. The settled solids shear strength and other observations of the settled solids are described in Table 3-20. 
WSRC-TR-2003-00390, REVISION 0

SRT-RPP-2003-00185, REVISION 0

Table 3-20. Shear Strength and Observations of Settled LAW AZ-102 Melter Feed

\begin{tabular}{|c|c|c|}
\hline $\begin{array}{c}\text { LAW-102 Settled } \\
\text { Solids }\end{array}$ & $\begin{array}{l}\text { Shear } \\
\text { Strength } \\
\text { (Pa) }\end{array}$ & Observations \\
\hline $\begin{array}{c}1.0 \mathrm{M} \mathrm{Na}, 3 \text { days of } \\
\text { mixing }\end{array}$ & 218 & $\begin{array}{l}\text { - After the measurement, the vane was manually placed into settled } \\
\text { solids and rotated manually (using researcher's hand) to inspect } \\
\text { the settled solids. Based on this observation, the material at the } \\
\text { top yielded much easier than the material at bottom. } \\
\text { - The sample was homogenized and allowed to settle for } 5 \\
\text { additional days. After the supernatant was analyzed, the settled } \\
\text { solids were inspected using the vane and these settled solids } \\
\text { strength was consistent throughout the sample and comparable } \\
\text { (manually) with the resistance felt in the 1.3M Na sample. }\end{array}$ \\
\hline $\begin{array}{c}\text { 1.0M Na, } 7 \text { days of } \\
\text { mixing }\end{array}$ & $\begin{array}{l}122\left(1^{\text {st }}\right) \\
494\left(2^{\text {nd }}\right)\end{array}$ & $\begin{array}{l}\text { - Same observation as above relative to how the material yielded } \\
\text { from top to bottom by manually using the vane to inspect the } \\
\text { settled solids. } \\
\text { - } 2^{\text {nd }} \text { measurement confirms how material felt via the vane. } \\
2^{\text {nd }} \text { measurement results could be impacted by bottom of wall and } \\
\text { from sheared material on upper section and above the vane. } \\
\text { Results indicate a shear strength gradient exists in the settled } \\
\text { solids. }\end{array}$ \\
\hline $\begin{array}{c}1.3 \mathrm{M} \mathrm{Na}, 1 \text { day of } \\
\text { mixing }\end{array}$ & 2349 & $\begin{array}{l}\text { - After measurement, the vane was used to manually inspect settled } \\
\text { solids. Unlike the } 1.0 \mathrm{M} \text { Na settled solids, the material felt } \\
\text { consistent throughout the sample. }\end{array}$ \\
\hline General & & $\begin{array}{l}\text { - After the settled solids were homogenized, the slurry was very } \\
\text { fluid and behaved like the original slurry and settled fairly } \\
\text { quickly. This was true for all the slurries. } \\
\text { - Homogenization of settled solids required that the vane make } \\
\text { physical contact with undistributed settled solids. }\end{array}$ \\
\hline
\end{tabular}




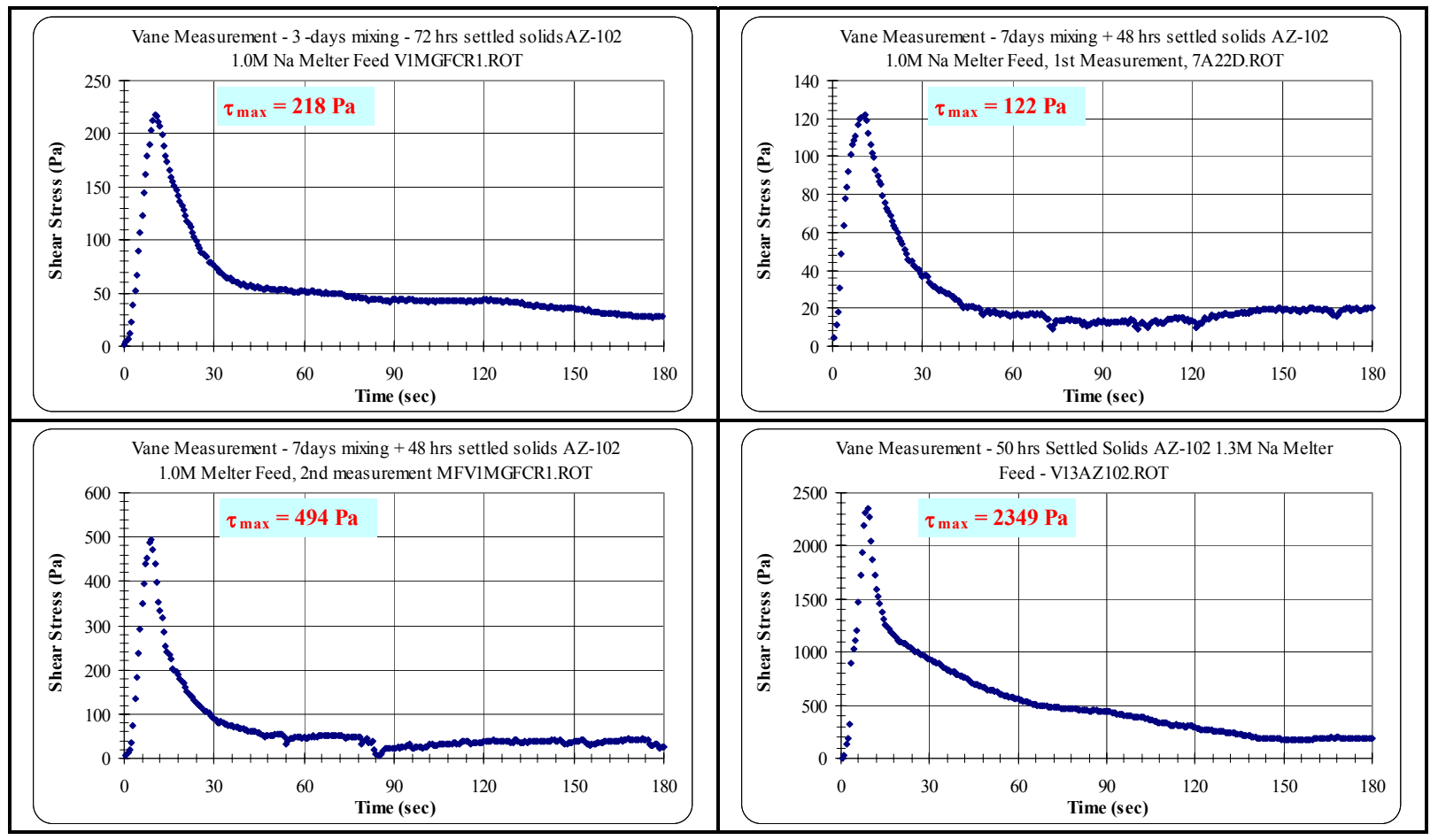

Figure 3-11. Vane Results of the LAW AZ-102 Settled Melter Feed

\subsection{PARTICLE SIZE DISTRIBUTION}

A Microtrac X-100 particle size analyzer was used to measure the particle size distribution (PSD) of these samples. Prior to analyzing the sample, the melter feed sample was diluted using a filtered simulant supernatant with approximately the same molarity as the feed sample. The Microtrac X-100 particle size analyzer measures the particle diameters by measuring the scattered light from a laser beam projected through a stream of the fluid carrying the diluted sample particles. The amount and direction of the light scattered by the particles is measured by an optical detector array and then analyzed to determine the size distribution of the particles. The Microtrac X-100 range is nominally 0.12 to $704 \mu \mathrm{m}$. It should be noted that this instrument does not have sonication (ultrasonic energy that breaks up agglomerations) capabilities; hence, no PSD measurements were taken with sonication. The Microtrac X-100 has software that was utilized to calculate the mean number, mean area, mean volume and number and volume distribution data for standards and melter feed. 
The X-100 was functionally checked at the beginning and at the end of the melter feed PSD measurements using NIST traceable particle size standards from Duke Scientific Corporation. These particle size standards are polystyrene micro spheres dispersed in a $1 \mathrm{mM}$ potassium chloride solution. The particle size standards were diluted using de-ionized water as the suspending medium (refractive index of mixture was set to 1.33) and a nominal flow rate of $40 \mathrm{~mL} / \mathrm{s}$. The X-100 instrument was set to 'transparent' mode with the particle refractive index equal to 1.59 and particle shape as spherical. A small size, $39.6 \mu \mathrm{m} \pm 0.8 \mu \mathrm{m}$, and a larger size, $496 \mu \mathrm{m} \pm 10 \mu \mathrm{m}$, particle size standard were used to verify the functionality of the Microtrac X-100. Each standard was run in triplicate with a measuring time of 30 seconds per measurement. The average of three measurements is reported. The standards were run before (initial) and after (final) the LAW AZ-102 melter feeds were analyzed. The Microtrac X-100 calculated the mean volume diameter and the mean number diameter and the results for the standards are presented in Table 3-21. Additional information for the Duke standards, including the volume distribution, the cumulative volume distribution, number distribution and the cumulative number distribution plots, and numerical data is presented in Figure A- 1 through Figure A- 4, Figure A- 11 and Figure A- 12 in Appendix A. Unfortunately, the larger particle size standard was consumed in the initial measurements, so only the smaller particle size standard was measured after the AZ-102 slurry was analyzed. The mean diameter of a distribution represents the centroid of the distribution. Instrument functionality is typically verified by comparing the calculated mean number diameter from measuring the PSD of the certified standard to the certified values of the standards. The calculated value is recommended to be within $\pm 10 \%$ of the standard for ideal instrumentation functionality verification as stated in reference 2 .

Table 3-21 shows the calculated mean diameters on a number and volume basis for both the smaller and larger standards. The calculated mean number and volume diameter are within $\pm 10 \%$ of the standard mean diameter, though only the number basis is required for instrument functionality.

Table 3-21. Summary of Particle Size Data for Standards

\begin{tabular}{|c|c|c|c|c|c|}
\hline \multicolumn{2}{|c|}{ NIST Traceable Particle Size Standard } & \multicolumn{3}{c|}{$\begin{array}{c}\text { Measured Mean and Medium Diameters on a } \\
\text { Number and Volume Basis }(\mu \mathrm{m})\end{array}$} \\
\hline Description & $\begin{array}{c}\text { Mean } \\
\text { Diameter }(\mu \mathrm{m})\end{array}$ & Initial Measurements & \multicolumn{2}{c|}{ Final Measurements } \\
\cline { 3 - 7 } & Number & Volume & Number & Volume \\
\hline Duke Scientific Standard 2040A & $39.6 \pm 0.8$ & 37.67 & 40.45 & 38.23 & 39.89 \\
\hline Duke Scientific Standard 4350A & $497 \pm 10$ & 495.9 & 535.1 & N/M & N/M \\
\hline
\end{tabular}

$\mathrm{N} / \mathrm{M}=$ not measured 


\section{WSRC-TR-2003-00390, REVISION 0 SRT-RPP-2003-00185, REVISION 0}

After the initial particle size standards were measured on the Microtrac X-100, the $1.0 \mathrm{M} \mathrm{Na}$ and 1.3M Na LAW AZ-102 melter feeds PSD measurements were performed. These melter feeds were diluted using an LAW AZ-102 pretreated waste simulant as the suspending medium with a nominal flow rate of $40 \mathrm{~mL} / \mathrm{s}$. The LAW AZ-102 pretreated waste simulant is described in detail in an SRTC interim report on the AZ-102 LAW vitrification testing [Ref. 5]. The LAW AZ-102 pretreated waste simulant was diluted to the appropriate $\mathrm{Na}$ molarity of the melter feed and filtered through a $0.2 \mu \mathrm{m}$ filter prior to being used to dilute the slurry sample. The Microtrac X-100 was set to 'Absorb' mode with particle shape, particle refractive index and fluid refractive index unspecified. For each melter feed sample, a homogenized subset sample was taken and diluted with the LAW AZ-102 pretreated waste simulant. Five homogenized subsets of this sample were then analyzed, using a 60 second cycle time, through the Microtrac X-100. The average of the five measurements is reported in Table 3-22.

Table 3-22 summarizes the mean and medium data for the melter feed PSD for both volume and number basis. Additional information for the three different melter feeds, including volume distribution, cumulative volume distribution, number distribution, cumulative number distribution plots, numerical data, and Microtrac X-100 operating conditions is presented in Appendix A (Figure A- 5 through Figure A-10). The plots of the particle size of the melter feed slurry particles, in Appendix A, show the percentage of particles that pass (right $\mathrm{Y}$-axis, histogram) and percent cumulative of particles that have passed (left $\mathrm{Y}$-axis, solid line) for a given micron size range (X-axis). This data is also shown in tabular form, located below the plots.

The volume basis data for the melter feeds show that they consist of particles in the $0.122 \mu \mathrm{m}$ to $352 \mu \mathrm{m}$ range. Similar data for the number basis data indicates particle sizes between $0.122 \mu \mathrm{m}$ to $10 \mu \mathrm{m}$ range. Both the volume basis and the number basis plots show that the distribution of particles in these melter feed slurries is contained in two different groups (bimodal distribution). The volume basis data indicates the smaller group centered around $1.5 \mu \mathrm{m}$ and the larger group is centered around $30 \mu \mathrm{m}$.

The number basis data, which is weighed towards smaller particles, indicates that the smaller group is centered around $0.15 \mu \mathrm{m}$ and the larger group is centered around $0.3 \mu \mathrm{m}$. The number distribution typically yields smaller mean and median values as compared to volume distribution for a wide distribution of diameters. The number distribution is based on the volume distribution, with the cube of the diameter divided into the volume distribution, hence yielding a higher number distribution for smaller diameter particles. Note: The carrier fluid used was an AZ-102 pretreated waste simulant that was filtered using a $0.2 \mu \mathrm{m}$ filter.

No baseline PSD measurements were made of the filtered LAW AZ-102 pretreated waste simulant. The impact of solids smaller than $0.2 \mu \mathrm{m}$ in the AZ-102 pretreated waste simulant would bias the number results in the direction of smaller particle size data. From a numbers perspective, many of the individual GFCs have number distributions that contain particles that are also in this range [Ref. 4]. This would have little impact on the volume distribution, which is typically the data used for performing engineering calculations relative to settling. 
Table 3-22 shows the mean and median values for the volume and number for the melter feeds. The mean number indicates that there are a lot of small particles in all the melter feeds. The mean volume indicates the large particles, though not as numerous as the small particles, have a much larger impact on the volume. This is expected since volume is a cubic function of the diameter. There was little difference between the data sets. After 3 days and 7 days of mixing, there was little change in the LAW AZ-102 1.0M Na melter feed. This was also reflected in the physical and rheological results. The LAW AZ-102 1.3M Na melter feed had slightly larger particles than the LAW AZ-102 1.0M Na melter feed.

Table 3-22. Summary of Particle Size Distribution Data for Melter Feeds

\begin{tabular}{|c|c|c|c|c|c|c|}
\hline \multirow{2}{*}{$\begin{array}{c}\text { LAW AZ-102 Melter } \\
\text { Feed Description }\end{array}$} & \multicolumn{3}{|c|}{ Volume } & \multicolumn{3}{c|}{ Number } \\
\cline { 2 - 7 } & \multicolumn{2}{|c|}{ Mean } & Median & \multicolumn{2}{c|}{ Mean } & Median \\
\cline { 2 - 7 } & $\mu \mathrm{m}$ & $\%$ Pass & $\mu \mathrm{m}$ & $\mu \mathrm{m}$ & $\%$ Pass & $\mu \mathrm{m}$ \\
\hline $1.0 \mathrm{M} \mathrm{Na}$, 3 days mixing & 28.86 & 65.6 & 17.62 & 0.353 & 69.0 & 0.283 \\
\hline $1.0 \mathrm{M} \mathrm{Na}$, 7 days mixing & 27.32 & 64.2 & 16.89 & 0.361 & 68.6 & 0.287 \\
\hline $1.3 \mathrm{M} \mathrm{Na}$ 1 day mixing & 30.53 & 67.4 & 17.08 & 0.354 & 68.6 & 0.284 \\
\hline
\end{tabular}

\subsection{COMPOSITIONAL DATA}

\subsubsection{Pretreated Waste Composition}

The LAW AZ-102 pretreated waste compositions were not analytically measured, but calculated. To calculate the pretreated waste compositions, the AZ-102 concentrate analysis of the original LAW AZ-102 4.38M Na pretreated waste reported in Table 5 of WSCR-TR20001-00395 [Ref. 5] was used. The data reported in Table 5 [Ref. 5] are in units of radioactivity per unit volume, mass per unit volume or molarity. The average analyte values in Table 5 [Ref. 5] which have a reportable level above the minimum reportable quantity levels were used. The volumes of the $1.0 \mathrm{M} \mathrm{Na}$ and $1.3 \mathrm{M} \mathrm{Na}$ and that of the $4.38 \mathrm{M} \mathrm{Na}$ pretreated waste were determined after the diluted feeds were corrected (via evaporation) for their targeted molarities and the volumes are shown in Table 3-23.

Table 3-23. Volume of Pretreated Waste

\begin{tabular}{|c|c|c|}
\hline \multirow{2}{*}{ Pretreated waste } & \multicolumn{2}{|c|}{ Volume (mL) } \\
\cline { 2 - 3 } & $4.38 \mathrm{M} \mathrm{Na}$ Solution Used & Final waste \\
\hline LAW AZ-102 $1.0 \mathrm{M} \mathrm{Na}$ & 50.20 & 187.45 \\
\hline LAW AZ-102 $1.3 \mathrm{M} \mathrm{Na}$ & 31.55 & 86.95 \\
\hline
\end{tabular}


The LAW AZ-102 1.0M Na and 1.3M Na pretreated waste analytes were determined using Equation 3-8 and the results are shown in Table 3-24.

Equation 3-8 $\rho_{i, j}=\rho_{i, 4.38 M} \frac{V_{4.38 M, j}}{V_{j}}, \hat{\alpha}_{i, j}=\hat{\alpha}_{i, 4.38 M} \frac{V_{4.38 M, j}}{V_{j}}, M_{i, j}=M_{i, 4.38 M} \frac{V_{4.38 M, j}}{V_{j}}$ where: $\rho_{\mathrm{i}, \mathrm{j}}=$ density of analyte i for $\mathrm{j} \mathrm{M}$ Na pretreated waste $(\mathrm{mg} / \mathrm{L}$ or $\mu \mathrm{g} / \mathrm{L})$ $\rho_{\mathrm{i}, 4.38 \mathrm{M}}=$ density of analyte $\mathrm{i}$ in the $4.38 \mathrm{M} \mathrm{Na}$ pretreated waste $(\mathrm{mg} / \mathrm{L}$ or $\mu \mathrm{g} / \mathrm{L})$ $\hat{\alpha}_{i, j}=$ activity density of analyte i for $\mathrm{j} \mathrm{M} \mathrm{Na}$ pretreated waste $(\mu \mathrm{Ci} / \mathrm{L})$ $\hat{\alpha}_{i, 4.38 \mathrm{M}}=$ activity density of analyte $\mathrm{i}$ in the $4.38 \mathrm{M} \mathrm{Na}$ waste $(\mu \mathrm{Ci} / \mathrm{L})$ $\mathrm{M}_{\mathrm{i}, \mathrm{j}}=$ molarity of analyte $\mathrm{i}$ for $\mathrm{j} \mathrm{M} \mathrm{Na}$ pretreated waste (moles/L) $\mathrm{M}_{\mathrm{i}, 4.38 \mathrm{M}}=$ molarity of analyte $\mathrm{i}$ in the $4.38 \mathrm{M} \mathrm{Na}$ waste(moles $\left./ \mathrm{L}\right)$ $\mathrm{V}_{\mathrm{j}}=$ volume of the $\mathrm{j} \mathrm{M}$ Na pretreated waste (L)

$\mathrm{V}_{4.38 \mathrm{M}, \mathrm{j}}=$ volume of $4.38 \mathrm{M} \mathrm{Na}$ used to make the $\mathrm{j} \mathrm{M} \mathrm{Na}$ pretreated waste $(\mathrm{L})$

Table 3-24. Calculated 1.0M Na and 1.3M Na LAW Pretreated Waste Compositional Data

\begin{tabular}{|c|c|c|c|c|c|c|c|}
\hline \multirow{2}{*}{ Analytes } & \multirow{2}{*}{ Units } & \multicolumn{2}{|c|}{$\begin{array}{c}\text { LAW AZ-102 } \\
\text { Pretreated Waste }\end{array}$} & \multirow{2}{*}{ Analytes } & \multirow{2}{*}{ Units } & \multicolumn{2}{|c|}{$\begin{array}{c}\text { LAW AZ-102 } \\
\text { Pretreated Waste }\end{array}$} \\
\cline { 7 - 9 } & & $1.0 \mathrm{M} \mathrm{Na}$ & $1.3 \mathrm{M} \mathrm{Na}$ & & & $1.0 \mathrm{M} \mathrm{Na}$ & $1.3 \mathrm{M} \mathrm{Na}$ \\
\hline $\mathrm{Cs}-137$ & $\mu \mathrm{Ci} / \mathrm{L}$ & 329 & 446 & $\mathrm{NO}_{2}$ & $\mathrm{mg} / \mathrm{L}$ & 13239 & 17937 \\
\hline $\mathrm{Sr}-90$ & $\mu \mathrm{Ci} / \mathrm{L}$ & 332 & 450 & $\mathrm{SO}_{4}$ & $\mathrm{mg} / \mathrm{L}$ & 7043 & 9542 \\
\hline $\mathrm{Tc}-99$ & $\mu \mathrm{g} / \mathrm{L}$ & 1.6 & 2.2 & Oxalate & $\mathrm{mg} / \mathrm{L}$ & 1238 & 1678 \\
\hline 235 & $\mu \mathrm{g} / \mathrm{L}$ & 9.3 & 12.7 & $\mathrm{~F}$ & $\mathrm{mg} / \mathrm{L}$ & 367 & 497 \\
\hline 237 & $\mu \mathrm{g} / \mathrm{L}$ & 53.5 & 72.5 & $\mathrm{Al}$ & $\mathrm{mg} / \mathrm{L}$ & 213 & 289 \\
\hline 238 & $\mu \mathrm{g} / \mathrm{L}$ & 1024.3 & 1387.8 & $\mathrm{Ca}$ & $\mathrm{mg} / \mathrm{L}$ & 17.9 & 24.3 \\
\hline 239 & $\mu \mathrm{g} / \mathrm{L}$ & 20.1 & 27.3 & $\mathrm{Cr}$ & $\mathrm{mg} / \mathrm{L}$ & 272 & 369 \\
\hline $\mathrm{K}(\mathrm{AA})$ & $\mathrm{mg} / \mathrm{L}$ & 1220 & 1653 & $\mathrm{Mg}$ & $\mathrm{mg} / \mathrm{L}$ & 0.8 & 1.1 \\
\hline $\mathrm{Na}^{*}(\mathrm{AA}) * *$ & $\mathrm{mg} / \mathrm{L}$ & 23450 & 30576 & $\mathrm{Mo}$ & $\mathrm{mg} / \mathrm{L}$ & 21.2 & 28.7 \\
\hline Inorganic $(\mathrm{TIC})$ & $\mathrm{mg} / \mathrm{L}$ & 2516 & 3409 & $\mathrm{Na}$ & $\mathrm{mg} / \mathrm{L}$ & 23449 & 30576 \\
\hline Organic $(\mathrm{TOC})$ & $\mathrm{mg} / \mathrm{L}$ & 5333 & 7225 & $\mathrm{P}$ & $\mathrm{mg} / \mathrm{L}$ & 61.5 & 83.3 \\
\hline Free $\mathrm{OH}^{*}(\mathrm{M})$ & $\mathrm{M}$ & 0.29 & 0.40 & $\mathrm{~Pb}$ & $\mathrm{mg} / \mathrm{L}$ & 6.9 & 9.3 \\
\hline $\mathrm{CO}_{3}(\mathrm{M})$ & $\mathrm{M}$ & 0.13 & 0.18 & $\mathrm{Si}$ & $\mathrm{mg} / \mathrm{L}$ & 15.0 & 20.4 \\
\hline $\mathrm{NO}_{3}$ & $\mathrm{mg} / \mathrm{L}$ & 7312 & 9907 & $\mathrm{Sn}$ & $\mathrm{mg} / \mathrm{L}$ & 4.6 & 6.2 \\
\hline
\end{tabular}

** Measured values as reported 


\subsubsection{Melter Feed Composition}

The LAW AZ-102 1.0M Na and 1.3M Na melter feed compositions were also calculated. The mass of the analytes in Table 3-25 was determined for each waste stream using the volume of the pretreated waste compositions stated in Table 3-6. The elemental/compound mass contribution from the GFCs was determined by taking the mass of GFC used (Table 3-6), multiplying this number by the wt\% of the typical chemical makeup as stated in the summary data sheet of the specified GFC [Ref. 4] and then correcting it for elemental/ compound, if required. $\mathrm{CO}_{2}$ will be reported as a compound (not carbon). $\mathrm{Th} / \mathrm{U}$ in the Zircon sand will be reported as $\mu \mathrm{g} / \mathrm{L}$ of $\mathrm{Th} / \mathrm{U}$, since there is no breakdown of the individual elements. The composition of the individual GFCs taken from reference 4 and used are provided in Appendix B. The volume of the melter feed was then determined by dividing the sum of the masses of the pretreated feed and GFCs (Table 3-6) by the density of the melter feed (Table 3-10). For the 1.0M Na melter feed, the 3 day density was used. The masses of each analyte from the pretreated feeds and GFCs were added and then divided by the calculated volume. The calculated melter feed compositions are shown in Table 3-26. Note that due to the addition of sodium carbonate, the Na molarity of the melter feed is higher than that of the pretreated feed.

Table 3-25. Calculated 1.0M Na and 1.3M Na LAW Melter Feed Compositional Data

\begin{tabular}{|c|c|c|c|c|c|c|c|}
\hline \multirow{2}{*}{ Analytes } & \multirow{2}{*}{ Units } & \multicolumn{2}{|c|}{ LAW AZ-102 Melter Feed } & \multirow{2}{*}{ Analytes } & \multirow{2}{*}{ Units } & \multicolumn{2}{|c|}{ LAW AZ-102 Melter Feed } \\
\hline & & $1.0 \mathrm{M} \mathrm{Na}$ & $1.3 \mathrm{M} \mathrm{Na}$ & & & $1.0 \mathrm{M} \mathrm{Na}$ & $1.3 \mathrm{M} \mathrm{Na}$ \\
\hline Cs-137 & $\mu \mathrm{Ci} / \mathrm{L}$ & 220 & 273 & $\mathrm{Al}$ & $\mathrm{mg} / \mathrm{L}$ & 12931 & 15465 \\
\hline Sr-90 & $\mu \mathrm{Ci} / \mathrm{L}$ & 222 & 275 & $\mathrm{~B}$ & $\mathrm{mg} / \mathrm{L}$ & 23596 & 28194 \\
\hline Tc-99 & $\mu \mathrm{g} / \mathrm{L}$ & 1.1 & 1.33 & $\mathrm{Ca}$ & $\mathrm{mg} / \mathrm{L}$ & 36434 & 43538 \\
\hline 235 & $\mu \mathrm{g} / \mathrm{L}$ & 6.3 & 7.7 & $\mathrm{Cr}$ & $\mathrm{mg} / \mathrm{L}$ & 236 & 290 \\
\hline 237 & $\mu \mathrm{g} / \mathrm{L}$ & 35.8 & 44.3 & $\mathrm{Fe}$ & $\mathrm{mg} / \mathrm{L}$ & 27877 & 33316 \\
\hline 238 & $\mu \mathrm{g} / \mathrm{L}$ & 685.0 & 848.3 & $\mathrm{Li}$ & $\mathrm{mg} / \mathrm{L}$ & 5773 & 6896 \\
\hline 239 & $\mu \mathrm{g} / \mathrm{L}$ & 13.5 & 16.7 & $\mathrm{Mg}$ & $\mathrm{mg} / \mathrm{L}$ & 13672 & 16336 \\
\hline $\mathrm{U}+\mathrm{Th}$ & $\mu \mathrm{g} / \mathrm{L}$ & 16.3 & 19.5 & $\mathrm{Mn}$ & $\mathrm{mg} / \mathrm{L}$ & 107 & 128 \\
\hline $\mathrm{K}(\mathrm{AA})$ & $\mathrm{mg} / \mathrm{L}$ & 816 & 1010 & Mo & $\mathrm{mg} / \mathrm{L}$ & 14.2 & 17.5 \\
\hline $\mathrm{Na}(\mathrm{AA})$ & $\mathrm{mg} / \mathrm{L}$ & 29572 & 35308 & $\mathrm{Na}$ & $\mathrm{mg} / \mathrm{L}$ & 29572 & 35308 \\
\hline Inorganic (TIC) & $\mathrm{mg} / \mathrm{L}$ & 1683 & 2084 & $\mathrm{Nb}$ & $\mathrm{mg} / \mathrm{L}$ & 15.7 & 18.7 \\
\hline Organic (TOC) & $\mathrm{mg} / \mathrm{L}$ & 3566 & 4417 & $\mathrm{Ni}$ & $\mathrm{mg} / \mathrm{L}$ & 136 & 162 \\
\hline Free $\mathrm{OH}(\mathrm{M})$ & $\mathrm{M}$ & 0.20 & 0.24 & $\mathrm{P}$ & $\mathrm{mg} / \mathrm{L}$ & 83 & 101 \\
\hline $\mathrm{CO}_{3}(\mathrm{M})$ & $\mathrm{M}$ & 0.09 & 0.11 & $\mathrm{~Pb}$ & $\mathrm{mg} / \mathrm{L}$ & 4.6 & 5.7 \\
\hline $\mathrm{CO}_{2}$ & $\mathrm{mg} / \mathrm{L}$ & 60992 & 72887 & $\mathrm{Si}$ & $\mathrm{mg} / \mathrm{L}$ & 171015 & 204310 \\
\hline $\mathrm{NO}_{3}$ & $\mathrm{mg} / \mathrm{L}$ & 4890 & 6056 & $\mathrm{Sn}$ & $\mathrm{mg} / \mathrm{L}$ & 3.0 & 3.8 \\
\hline $\mathrm{NO}_{2}$ & $\mathrm{mg} / \mathrm{L}$ & 8854 & 10965 & $\mathrm{Ti}$ & $\mathrm{mg} / \mathrm{L}$ & 6789 & 8116 \\
\hline $\mathrm{SO}_{4}$ & $\mathrm{mg} / \mathrm{L}$ & 4710 & 5833 & $\mathrm{~V}$ & $\mathrm{mg} / \mathrm{L}$ & 28.2 & 33.8 \\
\hline Oxalate & $\mathrm{mg} / \mathrm{L}$ & 828 & 1026 & $\mathrm{Zn}$ & $\mathrm{mg} / \mathrm{L}$ & 29123 & 34809 \\
\hline $\mathrm{F}$ & $\mathrm{mg} / \mathrm{L}$ & 245 & 304 & $\mathrm{Zr}$ & $\mathrm{mg} / \mathrm{L}$ & 17750 & 21234 \\
\hline
\end{tabular}


WSRC-TR-2003-00390, REVISION 0

SRT-RPP-2003-00185, REVISION 0

\subsection{DISCUSSION ON BOUNDING PHYSICAL LIMITS AND DESIGN ISSUES}

The documents listed in Table 3-26 have been reviewed for bounding physical limits and design limits. Issues related to these documents, such as the shear strength are discussed in section 3.9.1 and pipeline transport issues and agitator speed for homogeneity are discussed in section 3.9.2. Rheological measurements with respect to the project-approved Guidelines [Ref. 1] are discussed in section 3.9.3.

Table 3-26. Bounding and Design Limit Documents

\begin{tabular}{|c|c|c|}
\hline $\begin{array}{l}\text { Document } \\
\text { Number }\end{array}$ & Ref. & Document Provides \\
\hline WTP-RPT-075 & 21 & 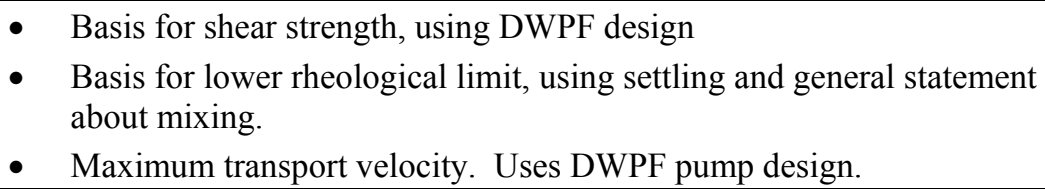 \\
\hline $\begin{array}{l}\text { 24590-WTP-3PS- } \\
\text { MPCO-T0006 }\end{array}$ & 22 & - $\quad$ RPP-WTP engineering LAW vitrification pumps specifications. \\
\hline $\begin{array}{l}\text { 24590-LAW-MPC- } \\
\text { LFP-00001 }\end{array}$ & 23 & - $\quad$ RPP-WTP engineering calculation for LAW vitrification pump sizing. \\
\hline $\begin{array}{l}\text { 24590-LAW-M6C- } \\
\text { LFP-00001 }\end{array}$ & 24 & $\begin{array}{l}\text { - RPP-WTP engineering calculation for LAW melter feed preparation } \\
\text { vessel volume levels. }\end{array}$ \\
\hline $\begin{array}{l}\text { 24590-WTP-3PS- } \\
\text { MACS-T0003 }\end{array}$ & 25 & - $\quad$ RPP-WTP engineering agitator specifications. \\
\hline
\end{tabular}

\subsubsection{Settled Solids Shear Strength}

The basis for the maximum shear strength limit is provided in WTP-RPT-075 and is described in detail in section 4.1.3. The basis assumes a $100 \mathrm{HP}$ motor starting torque, 36 " impeller diameter, 7.2" impeller width, and only one impeller completely immersed into settled slurry. The agitator parameters are based on the DWPF agitator design. The calculated maximum shear strength is $625 \mathrm{~Pa}$, based on these parameters and using the equation in Figure 4.2 of WTP-RPT-075. This maximum shear strength is also stated in 24590-LAW-M6C-LFP-00001, with the provision that the motor be sized to provide 1.5 times the maximum shear strength of $625 \mathrm{~Pa}$. The LAW AZ-102 1.3M Na melter feed settled shear strength was measured at 2349Pa, which well exceeds the basis calculation and agitator design limit. Table 3-27 provides a list of issues that should be considered relative to the settled solids shear strength measurements. 
WSRC-TR-2003-00390, REVISION 0 SRT-RPP-2003-00185, REVISION 0

Table 3-27. Issues with Shear Strength

\begin{tabular}{|c|l|}
\hline$\#$ & Issue \\
\hline 1 & WTP-RPT-075: Calculation was based on DWPF design, not on actual physical data. \\
\hline 2 & $\begin{array}{l}\text { WTP-RPT-075: Calculations used to determine the minimum yield stress necessary to prevent cavern } \\
\text { mixing, have not been performed. How this compares to the shear strength and physical data needs to be } \\
\text { considered. Problems with the development of a new tank bottom can develop if the settled solids are } \\
\text { continually not being re-suspended by the agitator. Cavern formation can be determined using } \\
\text { calculations outlined in references 26 through 29. }\end{array}$ \\
\hline 3 & $\begin{array}{l}\text { WTP-RPT-075: Calculations in this document must be performed using WTP design information, as it } \\
\text { becomes available. }\end{array}$ \\
\hline 4 & $\begin{array}{l}\text { 2490-LAW-M6C-LFP-00001: Shows that the top surface of the upper impeller for the LAW melter feed } \\
\text { preparation vessel (MFPV) is approximately a factor of 0.653 of the nominal operating volume. If that } \\
\text { condition exists, and electrical power was lost when the vessel was full, then both impellers would be } \\
\text { totally covered by settled solids. Basis calculation and design do not consider that the top impeller has } \\
\text { the potential to be covered by settled solids. Covering of the top impeller must be considered. }\end{array}$ \\
\hline 5 & $\begin{array}{l}\text { 24590-WTP-3PS-MPCO-T0006: Pump operation is undetermined at the time of this review. One of the } \\
\text { pumps uses an eductor priming line. Inactive use of this pump could be an issue, especially if the LAW } \\
\text { material builds strength in inactive mixing zones, such as the pump suction line, pump casing, and } \\
\text { eductor priming line. Physical testing should be performed to determine the frequency at which the } \\
\text { inactive pump must be operated. }\end{array}$ \\
\hline 6 & $\begin{array}{l}\text { General Issue: Settled solids in the pipe line will become an issue, e.g. in the case where power is lost } \\
\text { during transfer or if materials are not properly flushed from process lines. Flushing capabilities (e.g. } \\
\text { operational requirements) are unknown, at this time. Minimum flush velocity should be measured and } \\
\text { conditions of testing to cover potential plant operating upset conditions.. }\end{array}$ \\
\hline
\end{tabular}

\subsubsection{Transport Velocities and Homogeneous Mixing}

The LAW AZ-102 melter feeds are settling heterogeneous slurries which was obvious based on the results of the settling and rheology tests. For these types of slurries, a transitional (deposition) velocity as a minimum must be determined for pipe flow. The pipe velocity for homogenous flow may be required based on actual process conditions, and may be calculated using existing correlations. Existing correlations used to determine the transitional and homogenous flow velocities are available, but due to the complex combination of solids in the melter feed, it may be difficult to apply these correlations with a high level of confidence. Typically, pipe test flow loops are used to properly quantify these velocity limits and to validate the utilization of a correlation. References 30 through 32 provide methods that can be used to determine the necessary velocities in the pipeline. The lower viscosity limit as specified in WTP-RPT-075 should be used in these calculations.

WTP-RPT-075 calculates a lower viscosity of $0.4 \mathrm{cP}$ for homogenous mixing in an agitated tank, although no calculation was performed to determine agitator speed that would provide such homogeneity. Calculations or experimental data testing should be performed to determine the critical speed to achieve suspension (just off-bottom suspension), given the present design of the LAW MFPV and compared to the agitator speeds used in WTP-RPT075. References 33 through 36 provide methods that can be used to determine the mixing speeds. If calculations are to be performed, they should be performed in WTP-RPT- 075 . 
WSRC-TR-2003-00390, REVISION 0

SRT-RPP-2003-00185, REVISION 0

Use of any correlation may require obtaining the original technical document to determine the applicability of the correlation to the RPP-WTP process. The references listed are not all inclusive on work that has been performed concerning heterogeneous/homogenous mixing and transport issues.

\subsubsection{Rheology Issues}

The following rheological properties should be added to project-approved Guidelines [Ref. 1] or studied in more detail using simulants.

- The viscosity of the melter feed supernatant should be characterized. This would provide information about the LAW carrier fluid and could potentially be used to determine operating conditions. This can also be used for performing settling calculations.

- The settled solids shear strength as both a function of time and depth of settled solids, should also be determined. It was observed in this task that depth of settle solids shear strength and the rate at which the solid build strength are factors. Setting up of the melter feed settled solids were clearly evident within 15 to 30 minutes of lost agitation. The time at which the settled solids shear strength measurements are taken in settling slurry is also a factor. Settled solids shear strength needs to be studied to determine if mixing issues, such as agitator restart and solids resuspension, are possible given the current baseline design conditions.

\subsubsection{Other Issues}

The bubbles (foaming) due to the addition of GFCs (section 3.3.2) were from the addition of dry GFCs to the AZ-102 LAW pretreated waste stream. Foaming during processing could be an issue, if the foam gets up into areas of the MFPV where wetting would impact the operations of installed instrumentation or processes (e.g. GFC addition line) attached to the MFPV. The present RPP-WTP GFC delivery system at the vitrification facility will blend the dry GFCs with a predetermined amount of water prior to adding the GFCs to the MFPV via a chute. The wetted GFCs process has been designed to mitigate potential dusting issues related to delivering GFCs to the MFPV. No studies have been completed to date that investigated the potential impact of foaming relative to wetted (or dry) GFCs being blended into the MFPV. Because the final GFC delivery system and its interface with the MFPV are still being developed, the foaming issue will have to be addressed at a later date, preferably on a pilot scale process. 
WSRC-TR-2003-00390, REVISION 0

SRT-RPP-2003-00185, REVISION 0

This page intentionally left blank. 
WSRC-TR-2003-00390, REVISION 0

SRT-RPP-2003-00185, REVISION 0

\subsection{REFERENCES}

1. Smith, G.L. and Prindiville, K., "Guidelines for Performing Chemical, Physical, and Rheological Properties Measurements”, 24590-WTP-GPG-RTD-001, Rev. 0, May 20, 2002

2. “Test Exception to AZ-102 (Envelope B) LAW Vitrification Product Testing 24590-LAWTSP-RT-01-024, Rev. 0”, 24590-WTP-TEF-RT-03-005, April 3, 2003

3. Crawford, C.L., "RPP Test Specification: AZ102 (Envelope B) LAW Vitrification, Product Testing; Document \# 24590-LAW-TSP-RT-01-024, Rev. 0”, WSRC-TR-200200153, Rev. 0, May 6, 2002

4. Schumacher, R. "Characterization of HLW and LAW Glass Formers - Final Report", WSCR-TR-2002-00282, Rev. 1, July 15, 2003

5. Crawford, C.L., Ferrara, D.M., Schumacher, R.F. and Bibler, N.E., "Interim Report for Crucible Scale Active Vitrification of Waste Envelop B (AZ-102) (U)”, WSRC-TR-200100395, March 25, 2002

6. Email from Tommy Edwards to Erich Hansen, Subject Re: Follow Up, 8/28/03

7. Liddell, P.V. and Boger D.V., "Yield Stress Measurements with the vane", Journal of Non-Newtonian Fluid Mechanics, Vol. 63, pp 235-261, 1996

8. Nguyen, Q.D. and Boger D.V., "Yield Stress Measurements for Concentrated Suspensions", Journal of Rheology, Vol. 27, pp 321-349, 1983

9. Nguyen, Q.D. and Boger D.V., "Direct Yield Stress Measurement with the Vane Method”, Journal of Rheology", Vol. 29, pp 335-347, 1985

10. Barnes, H.A. and Nguyen, Q.D., "Review Rotating vane rheometry - a review", Journal of Non-Newtonian Fluid Mechanics, Vol. 98, pp 1-14, 2001

11. Saak, A.W., Jennings, H.M., and Shah S.P., "The influence of wall slip on yield stress and viscoelastic measurements of cement paste", Cement and Concrete Research, Vol. 31, pp 205-212, 2001

12. Barnes, H. A. and Carnali, J. O., "The vane-in-cup as a novel rheometer geometry for shear thinning and thixotropic materials", Journal of Rheology, Vol. 34, pp 841-866, 1990

13. Yoshimura, A. S., and Prud'Homme, P.K., “A Comparison of Techniques for Measuring Yield Stresses”, Journal of Rheology, Vol. 31, pp 699-710, 1987

14. Alderman, N. J., Meeten, G. H., and Sherwood, J. D., "Vane rheometry of bentonite gel", Journal of Non-Newtonian Fluid Mechanics, Vol. 91, pp 291-310, 1991

15. Mohseni, M., Kautola, H., and Allen D.G., "The Viscoelastic Nature of Filamentous Fermentation Broths and Its Influence on the Directly Measured Yield Stress", Journal of Fermentation and Bioengineering, Vol. 83, pp 281-286, 1997

16. Keating, J. and Hannant, D. J., "The Effect of Rotation Rate on Gel Strength and Dynamic Yield Strength of Thixotropic Oil Well Cements Measured Using a Shear Vane", Journal of Rheology, Vol. 33, pp 1011-1020, 1989

17. Wardhaugh, L. T. and Boger, D. V., "The measurement and description of the yielding behavior of waxy crude oil", Journal of Rheology, Vol. 35, pp 1121-1165, 1991

18. Yan, J. and Jame, A.E., 'The yield surface of viscoelastic and plastic fluids in a vane viscometer", Journal of Non-Newtonian Fluid Mechanics", Vol. 70, pp 237-253, 1997

19. Turian, R. M., Ma, T. W., Hsu, F.L.G., and Sung, D. J., "Characterization, settling, and rheology of concentrated fine particle mineral slurries", Power Technology, Vol. 93, pp. 219-233, 1997 
WSRC-TR-2003-00390, REVISION 0

SRT-RPP-2003-00185, REVISION 0

20. Iyer, R.S. and Stanmore B., "The effect of water absorption and the role of fines on the yield stress of dense fly ash slurries", Cement and Concrete Research, Volume 29, pp 765-767, 1999

21. Poloski, A., Smith, H., Smith., G., and Calloway B., WTP-RPT-075, Rev. 0, "Interim Report: Development of LAW and HLW Vitrification Physical Property Bounding Conditions and Simulant Verification Criteria", March 2003

22. 24590-WTP-3PS-MPCO-T0006, "RPP-WTP Engineering Specification for VesselMounted Vertical Transfer Pumps”, Rev. 0, August 15, 2002

23. Calc. No. 24590-LAW-MPC-LFP-00001, "Melter 1 Feed Prep Vessel Pumps LFP-PMP00001A, 1B”, Rev. C, June 29, 2003

24. Calc. No. 24590-LAW-M6C-LFP-00001, “LFP-VSL-00001, 00003, 00005 Sizing”, Rev. $0 \mathrm{~A}$, December 13, 2002

25. 24590-WTP-3PS-MACS-T0003, “RPP-WTP Engineering Specification For Mechanical Agitators", Rev. 1,

26. Elson, T. P., Cheesman, D. J, and A. W. Nienow, "X-Ray Studies of Cavern Sizes and Mixing Performance With Fluids Possessing a Yield Stress", Chemical Engineering Science, Vol. 41, pp. 2555-2562, 1986

27. Etchells, A. W, Ford, W.N, and Short, D. G. R., "Mixing of Bingham Plastics On An Industrial Scale", Fluid Mixing III, pp. 271-285, Institution of Chemical Engineers, 1988

28. Elson, T.P., "The Growth of Caverns Formed Around Rotating Impellers During the Mixing of Yield Stress Fluids", Vol. 96, pp. 303-319, Chemical Engineering Communications, 1990

29. Hirata, Y. and Aoshima Y., "Formation and Growth of Cavern in Yield Stress Fluids Agitated Under Baffled and Non-Baffled Conditions", Vol. 74, pp. 438-444, Institution of Chemical Engineers, May 1996

30. Wasp, E. J., “Solid-Liquid Flow Slurry Pipeline Transportation”, Vol. 1, No. 4, Trans Tech Publications, 1977

31. Govier, G. W. and Aziz, K., "The Flow of Complex Mixtures in Pipe", Van Nostrand Reinhold Company, 1972

32. Shook, C. A. and Roco, M. C., "Slurry Flow Principle and Practice", Butterworth Heinemann, 1991

33. Zwietering, T. N., "Suspending of solid particles in liquid by agitators", Vol. 8, pp 244253, Chemical Engineering Science, 1958

34. Uhl, V. W. and Gray, J. B., "Mixing Theory and Practice - Volume II", Academic Press, 1967

35. Oldshue, J. Y., “Fluid Mixing Technology”, McGraw-Hill, 1983

36. Baldi, G., Conti, R., and Alaria, E., "Complete Suspension of Particles in Mechanically Agitated Vessels", Vol. 33, pp 21-25, Chemical Engineering Science, 1978 
APPENDIX A. PARTICLE SIZE DISTRIBUTION DATA

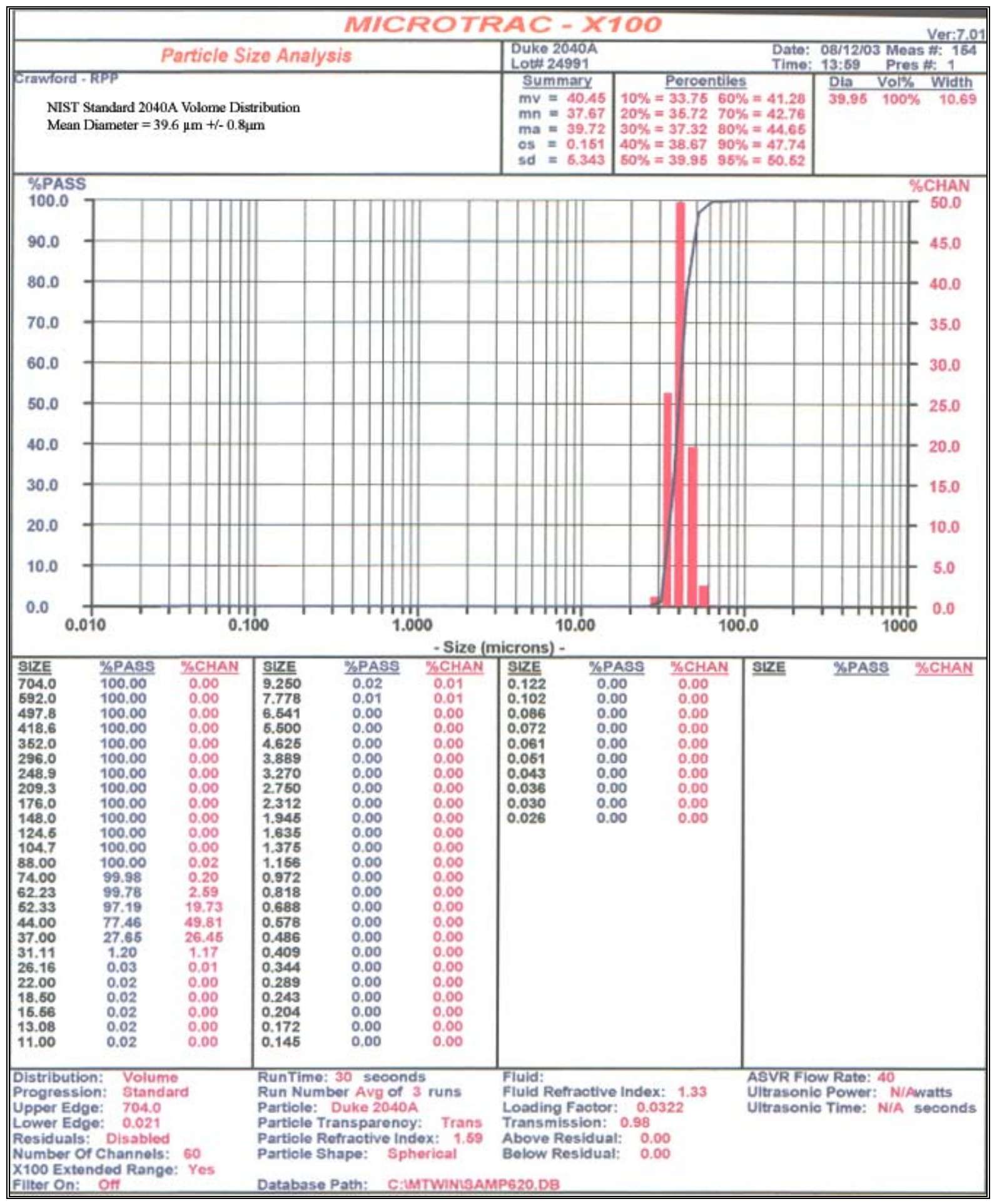

Figure A- 1. Initial Volume PSD - 2040A Standard 


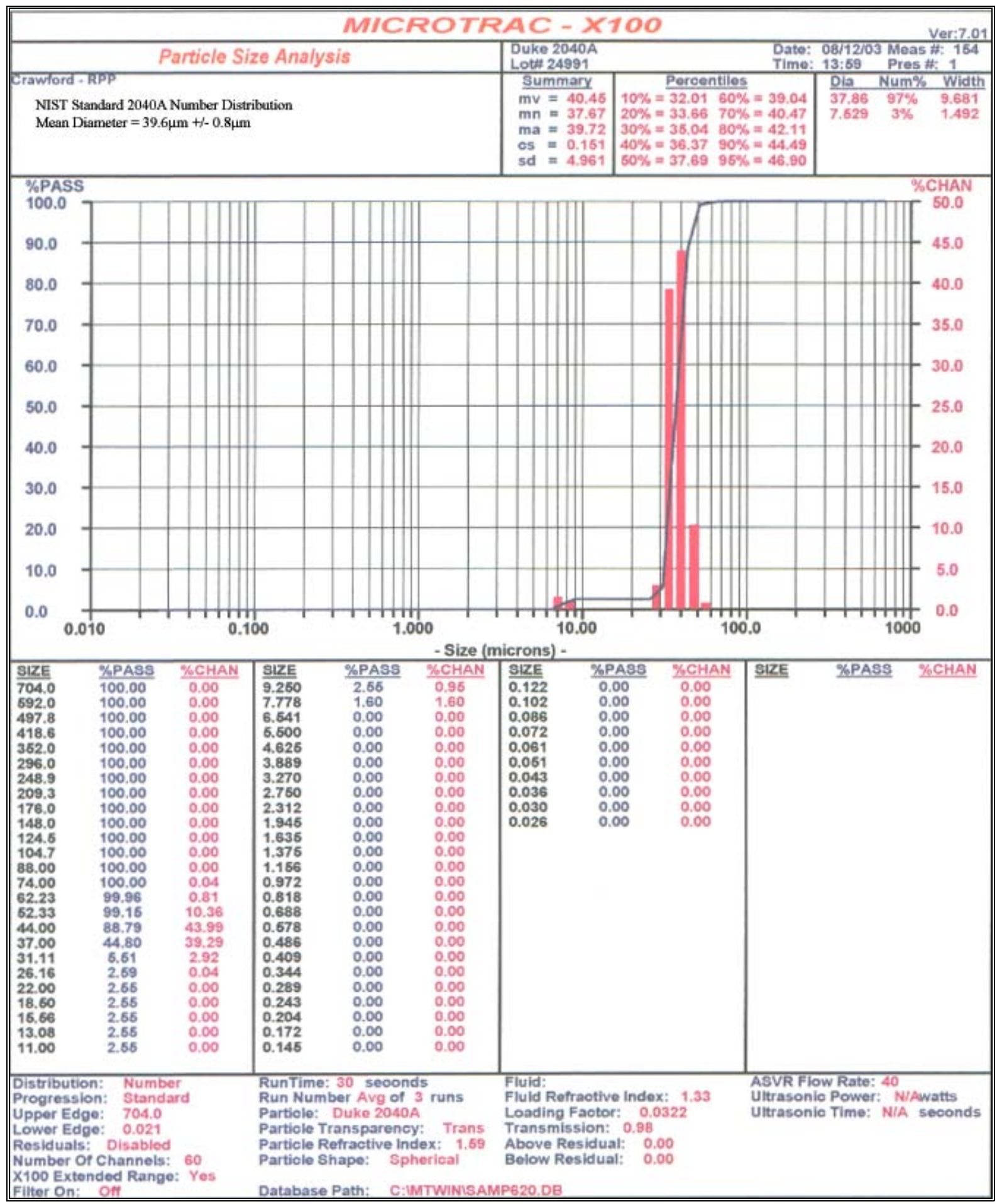

Figure A- 2. Initial Number PSD - 2040A Standard 


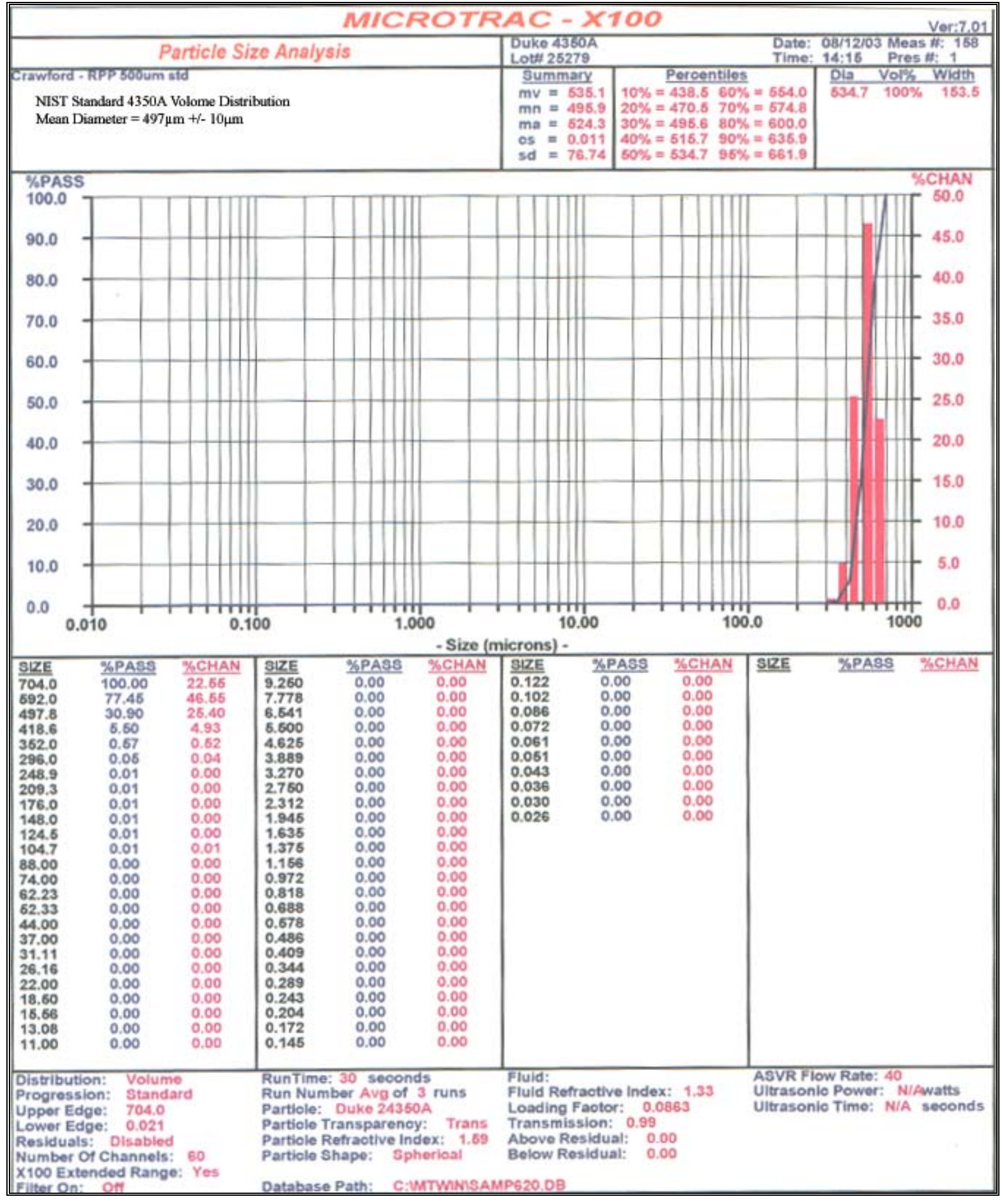

Figure A- 3. Initial Volume PSD - 4350A Standard 


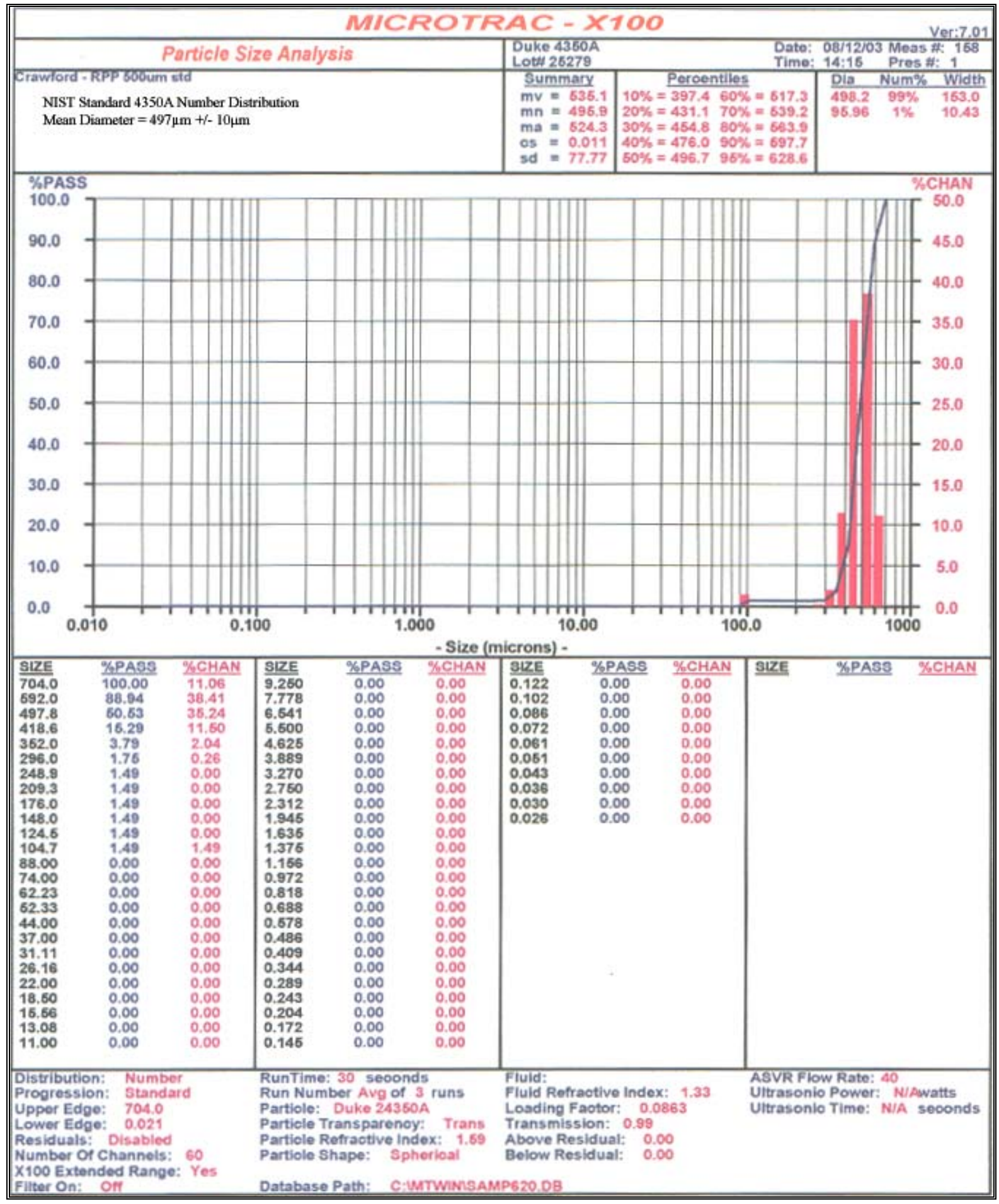

Figure A- 4. Initial Number PSD - 4350A Standard 


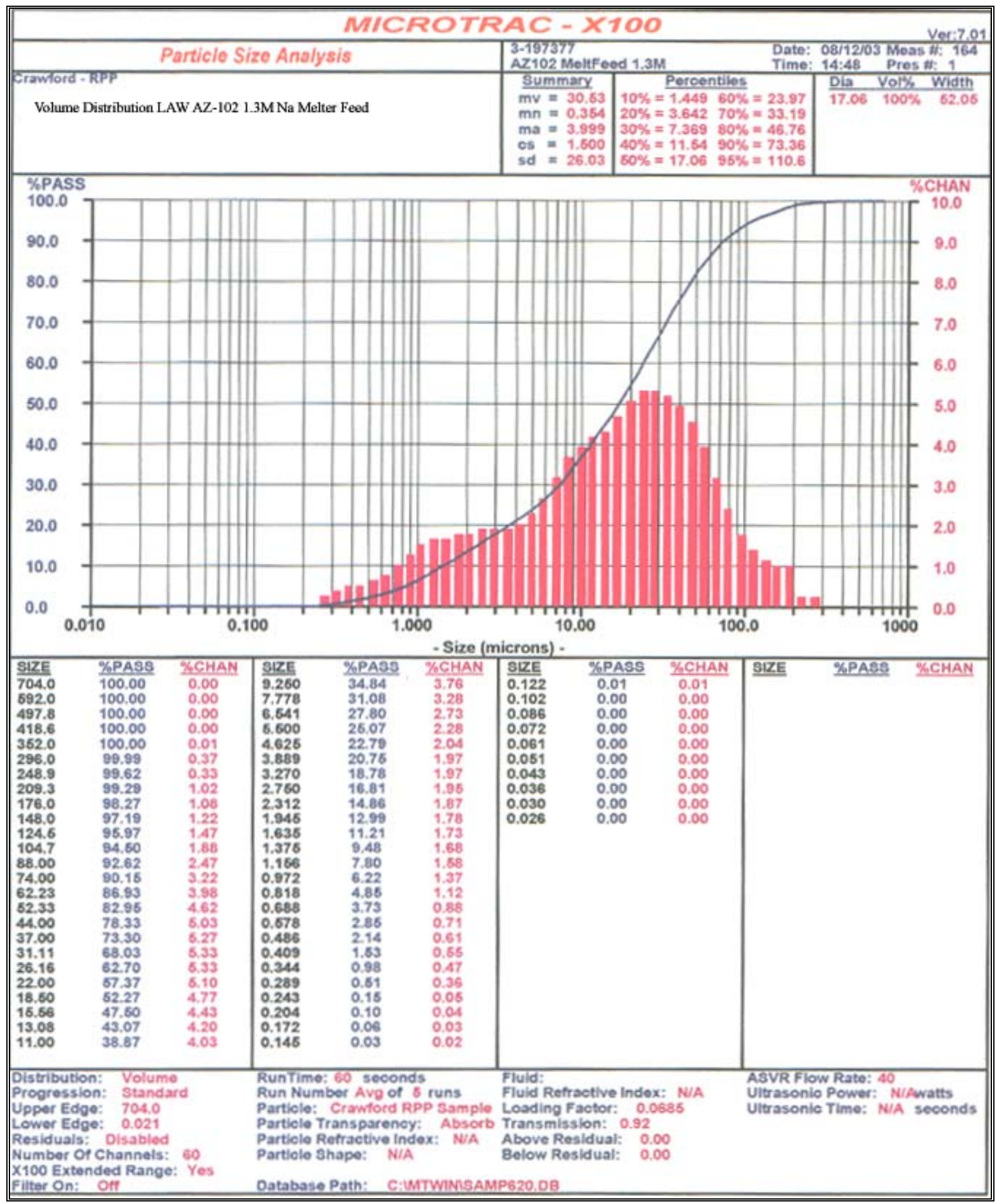

Figure A- 5. Volume PSD - LAW AZ-102 1.3M Na Melter Feed - 1 day mixing 


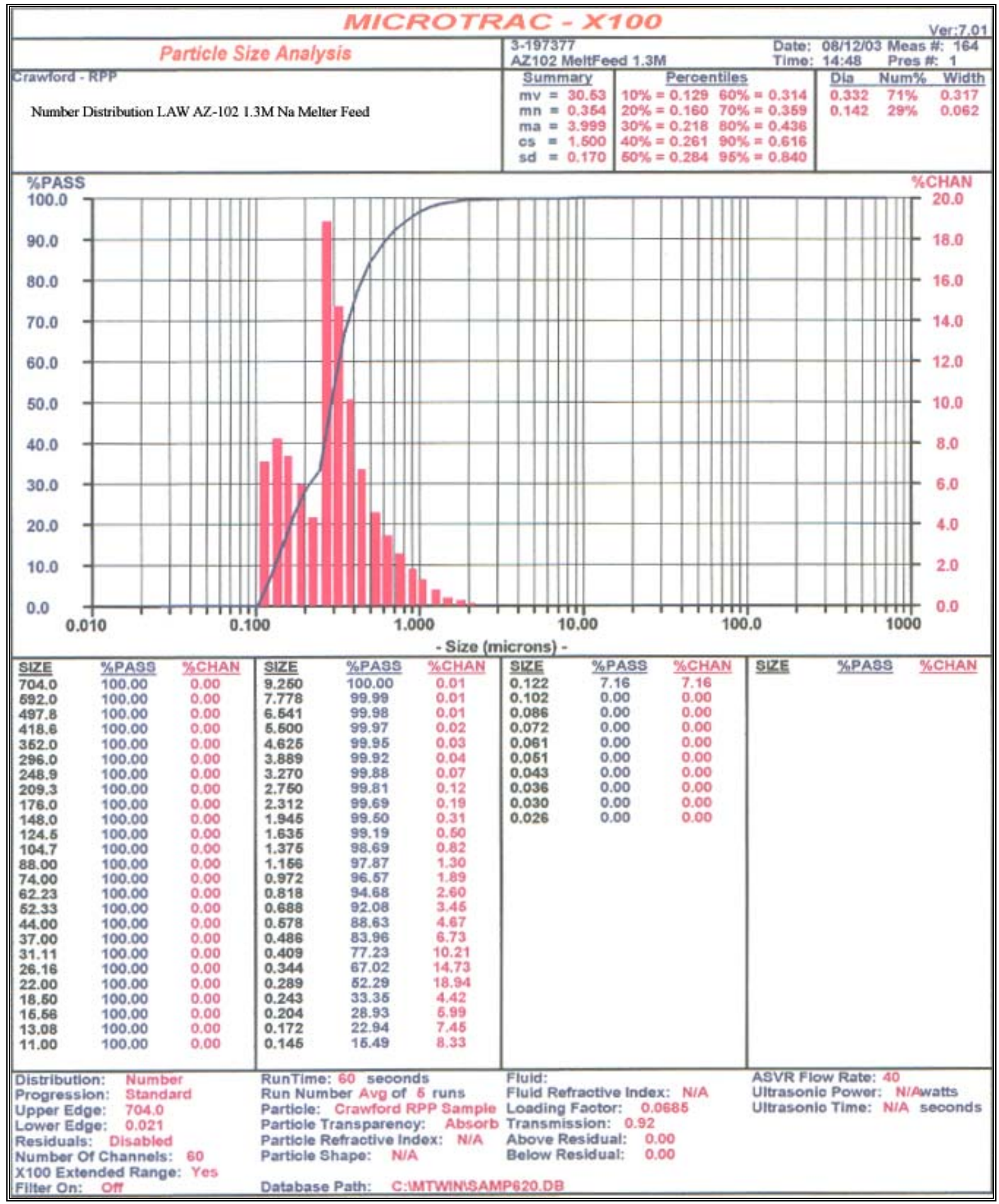

Figure A- 6. Number PSD - LAW AZ-102 1.3M Na Melter Feed - 1 Day Mixing 


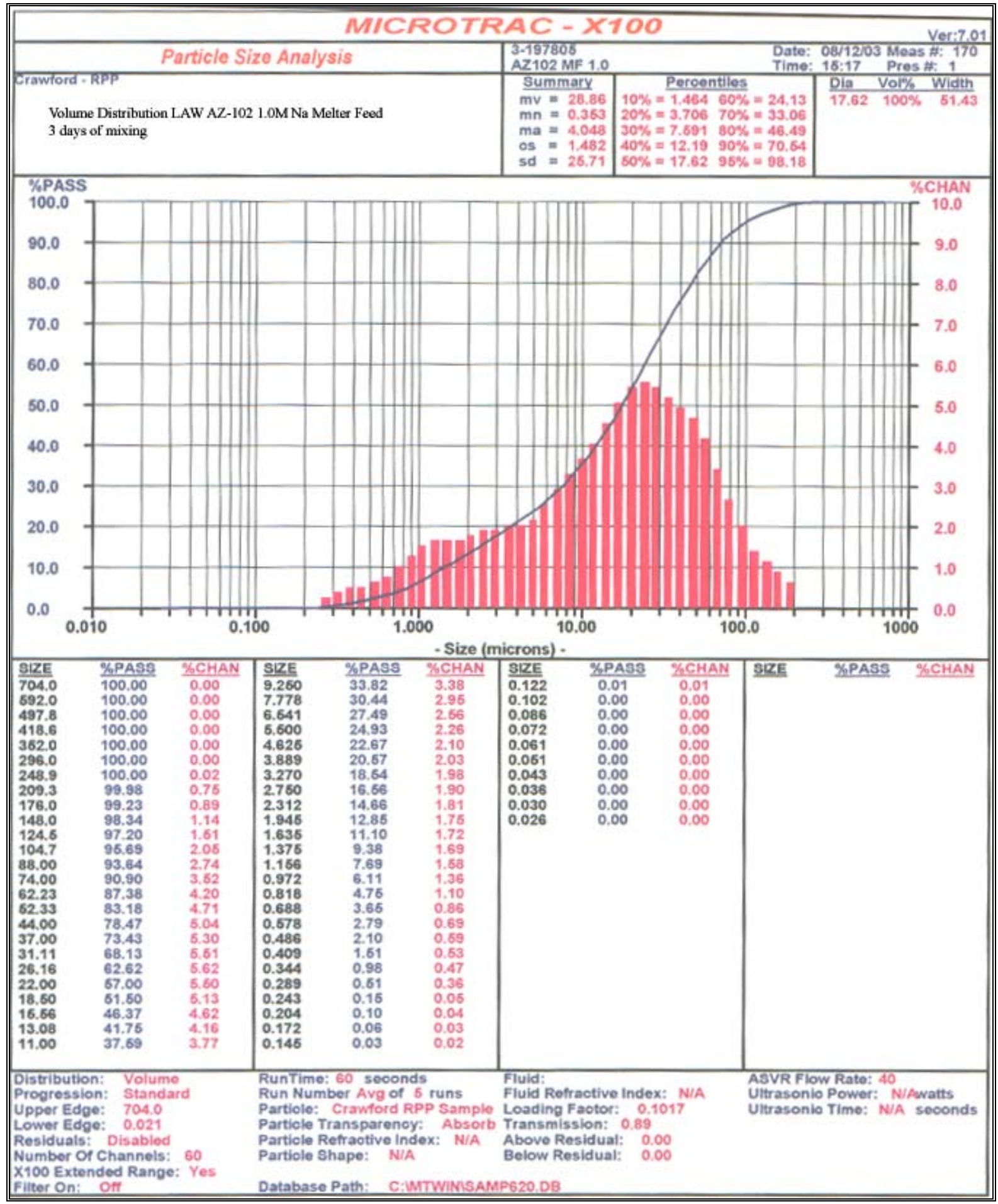

Figure A- 7. Volume PSD - LAW AZ-102 1.0M Na Melter Feed - 3 Days Mixing 


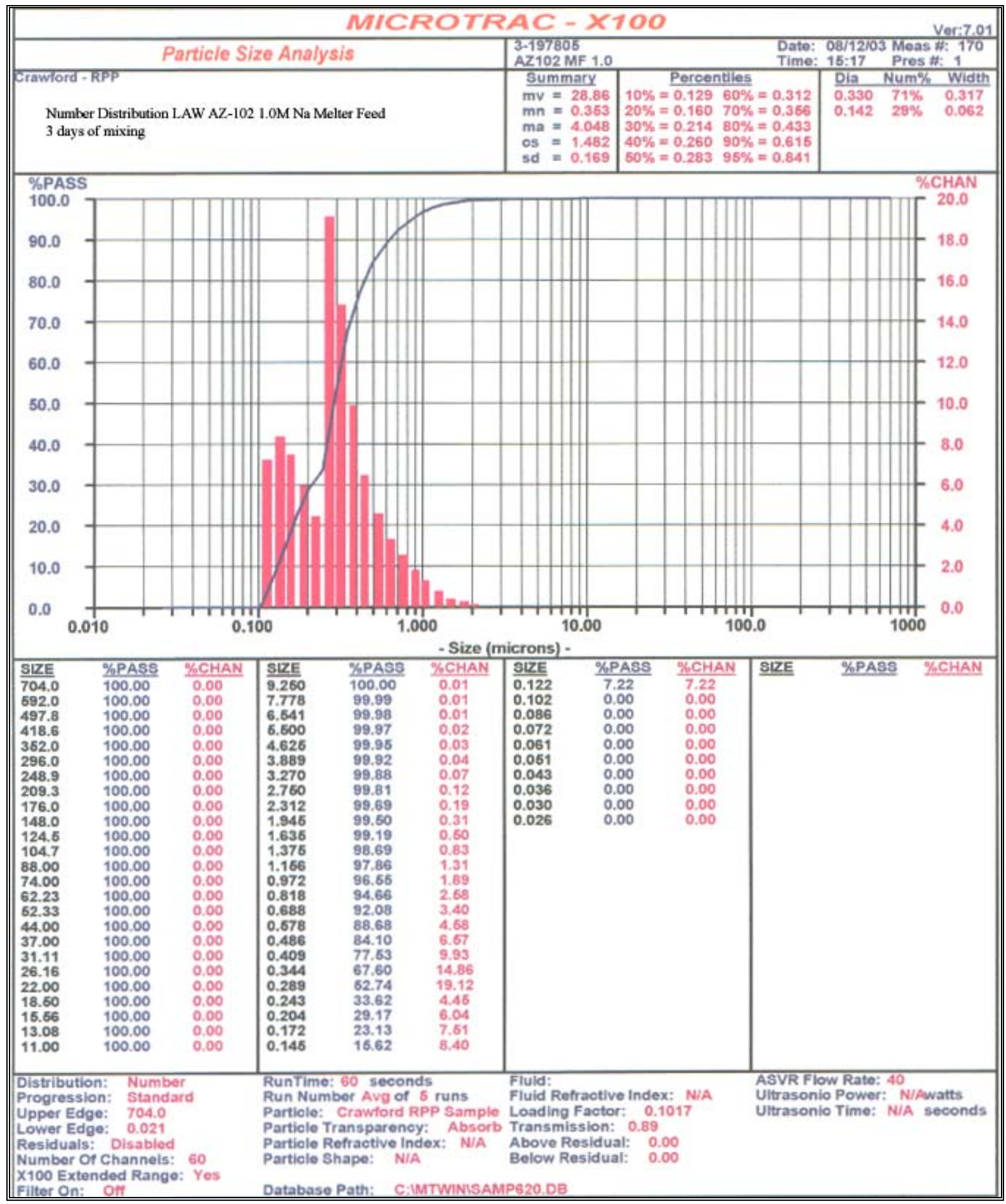

Figure A- 8. Number PSD - LAW AZ-102 1.0M Na Melter Feed - 3 Days Mixing 


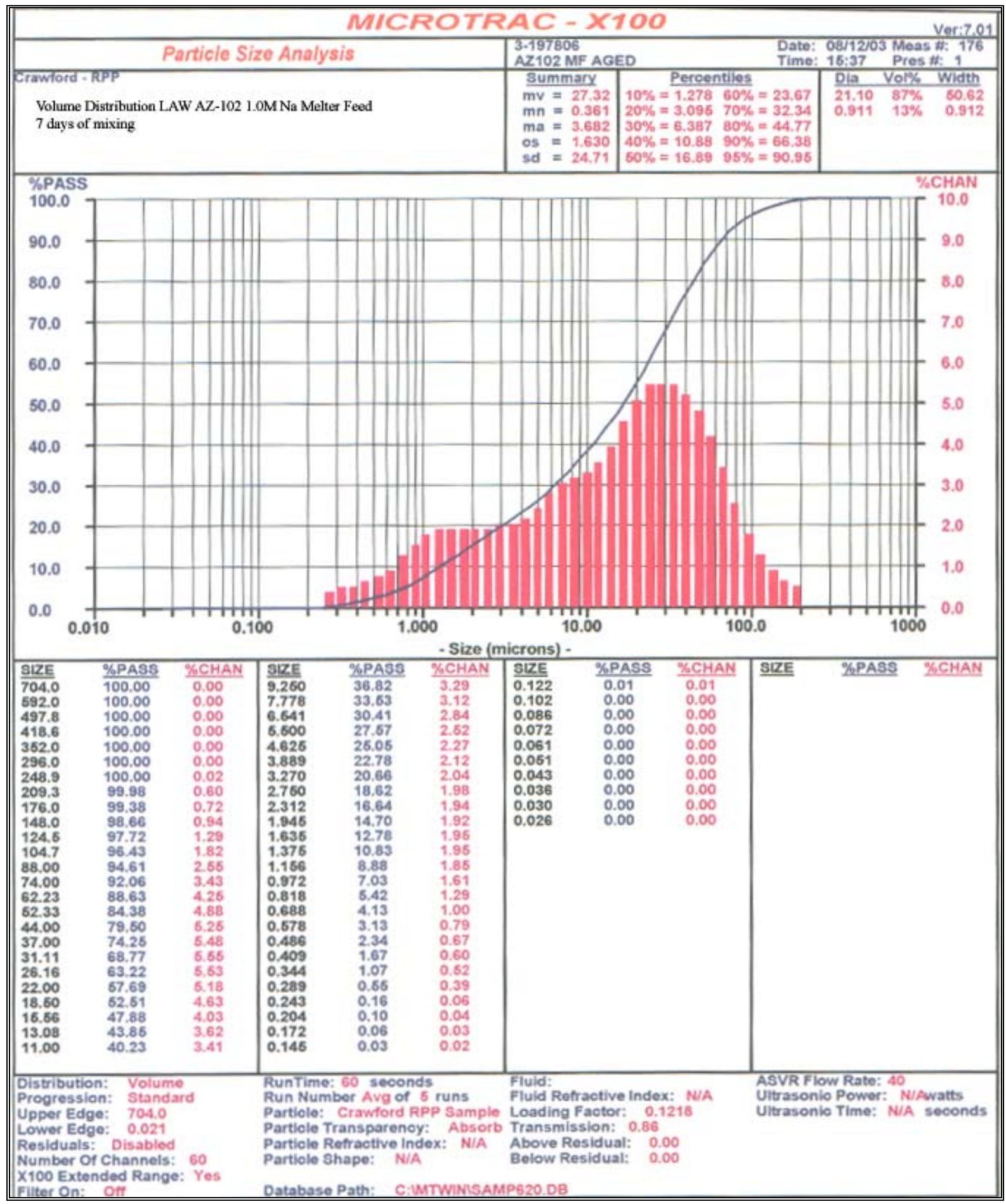

Figure A- 9. Volume PSD - LAW AZ-102 1.0M Na Melter Feed - 7 Days Mix 


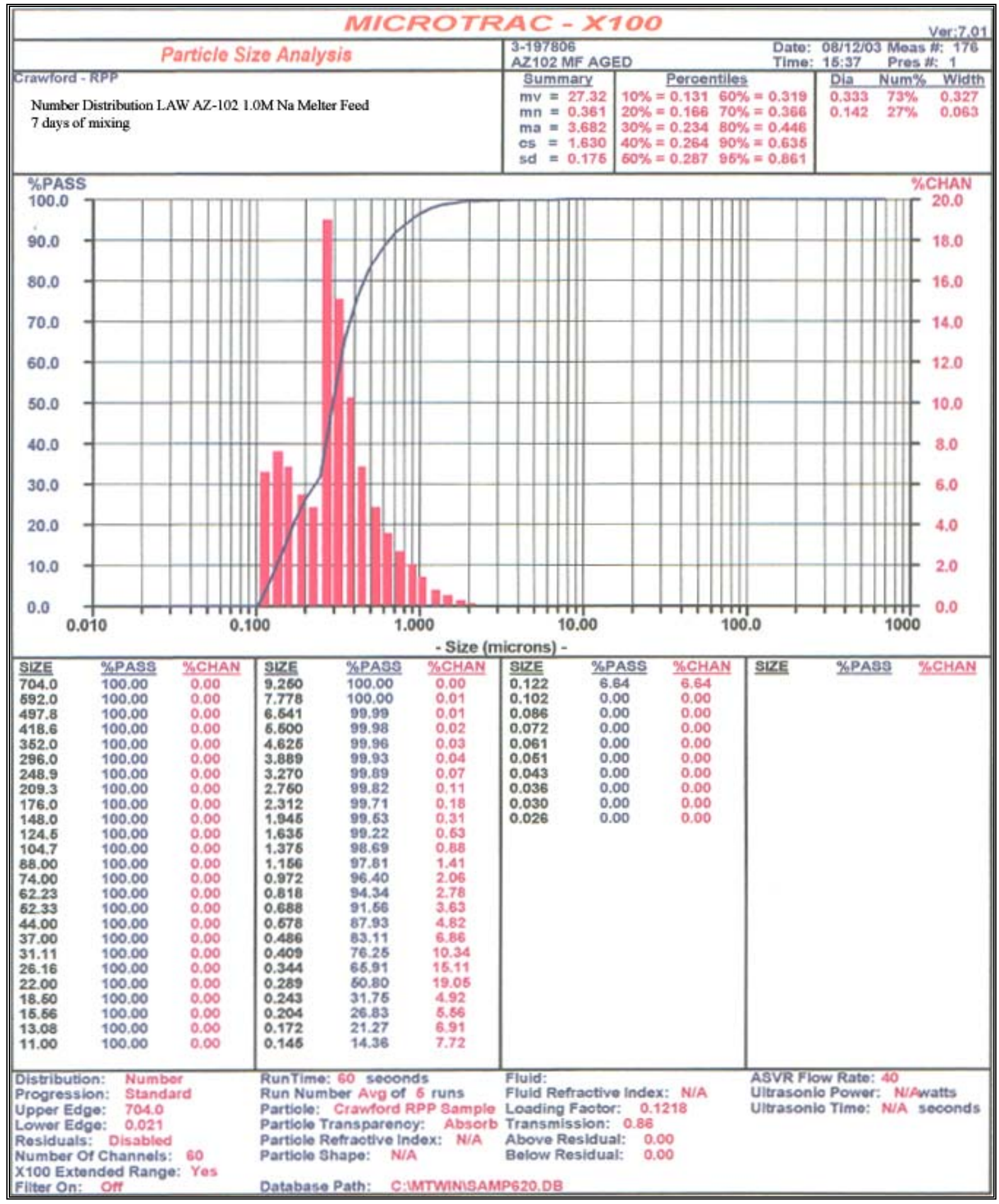

Figure A- 10. Number PSD - LAW AZ-102 1.0M Na Melter Feed - 7 Days Mixing 
SRT-RPP-2003-00185, REVISION 0

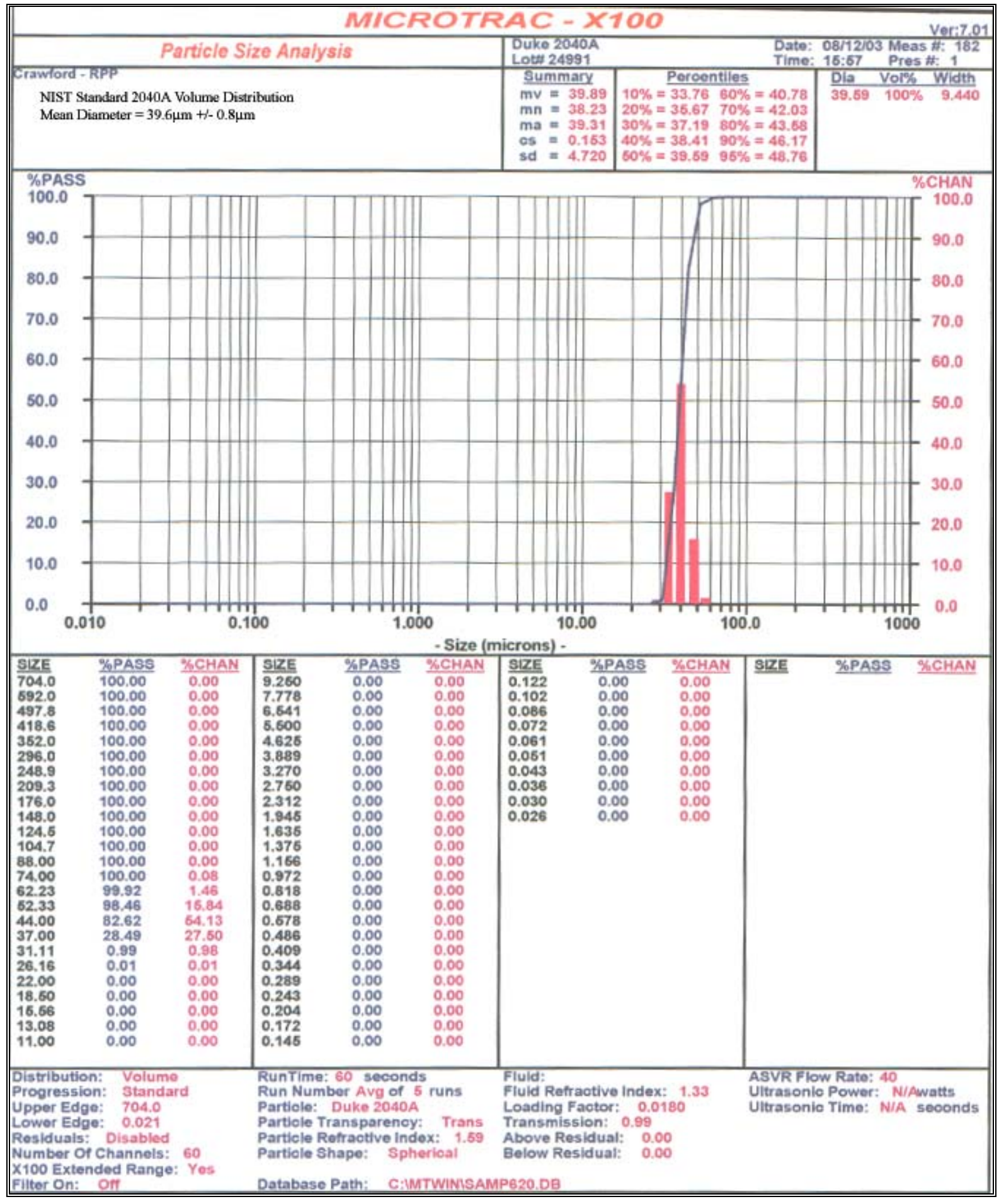

Figure A- 11. Final Volume PSD - 2040A Standard 


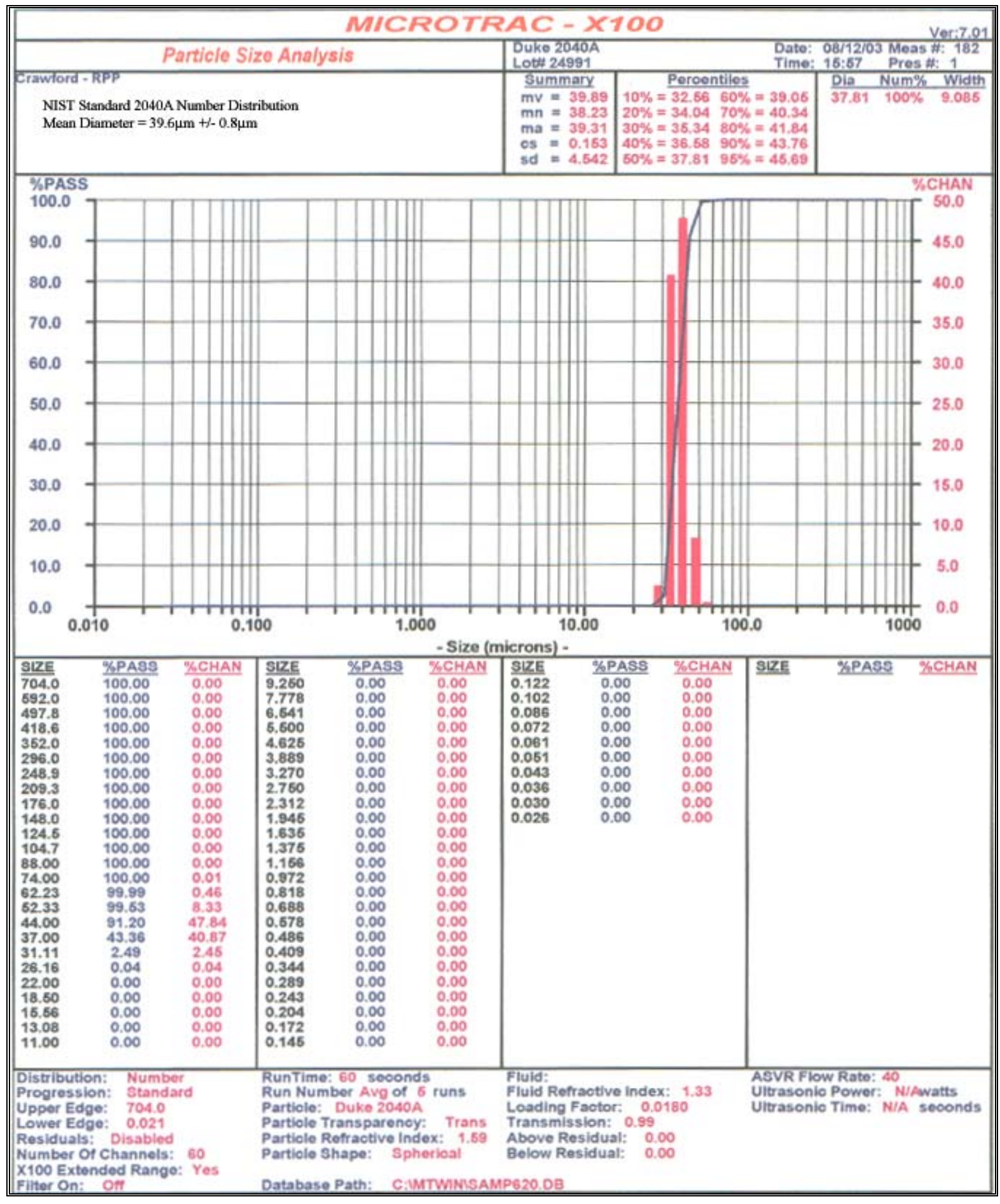

Figure A- 12. Final Number PSD - 2040A Standard 


\section{APPENDIX B. \\ COMPOSITION OF GLASS FORMER CHEMICALS}

The composition of each GFC used was taken from reference 4 and is summarized below

\begin{tabular}{|c|c|c|c|c|c|c|c|c|c|c|c|c|c|c|c|c|c|c|c|c|}
\hline \multirow{2}{*}{ Mineral } & \multicolumn{20}{|c|}{ nominal weight percent of compound in mineral } \\
\hline & ${ }_{2} \mathrm{O}_{3}$ & $\mathrm{~B}_{2} \mathrm{O}_{3}$ & $\mathrm{aO}$ & $\mathrm{CO}_{2}$ & $\mathrm{r}_{2} \mathrm{O}_{3}$ & ${ }_{2} \mathrm{O}_{3}$ & $\mathrm{H}_{2} \mathrm{O}$ & ${ }_{2} \mathrm{O}$ & $\mathrm{O}$ & $\mathrm{nO}$ & $\mathrm{a}_{2} \mathrm{O}$ & $\mathrm{Nb}_{2} \mathrm{O}_{5}$ & $\mathrm{iO}$ & $\mathrm{P}$ & $\mathrm{iO}_{2}$ & $\mathrm{TiO}_{2}$ & $\mathrm{~J}+\mathrm{Th}$ & $\mathrm{V}_{2} \mathrm{O}_{5}$ & $\mathrm{ZnO}$ & $\mathrm{ZrO}_{2}$ \\
\hline Kyanite & 57 & $\mathrm{~N} / \mathrm{A}$ & N/A & N/A & $\mathrm{N} / \mathrm{A}$ & 0.71 & N/A & $\mathrm{N} / \mathrm{A}$ & | & ת & $\mathrm{N} / \mathrm{A}$ & N/A & $\mathrm{N} / \mathrm{A}$ & $\mathrm{N} / \mathrm{A}$ & 40.5 & 1.05 & N/A & $\mathrm{N} / \mathrm{A}$ & $\mathrm{N} / \mathrm{A}$ & $\mathrm{N} / \mathrm{A}$ \\
\hline Boric Acid $-\mathrm{H}_{3} \mathrm{BO}_{3}$ & $\mathrm{~N} / \mathrm{A}$ & 56.5 & N/A & N/A & $\mathrm{N} /$ & $\mathrm{N} / \mathrm{A}$ & 43.5 & N/A & $\mathrm{N}$ & $\mathrm{N}$ & N/A & N/A & N/A & N/A & N/A & N/A & N/A & $\mathrm{N} / \mathrm{A}$ & $\mathrm{N} / \mathrm{A}$ & N/A \\
\hline $\mathrm{Na}_{2} \mathrm{CO}_{3}$ Anhyc & /A & N/A & N/A & 41.4 & $\mathrm{~N} / \mathrm{A}$ & N/A & N/A & $/ \mathrm{A}$ & N/A & N/A & 8.4 & $\mathrm{~J} / \mathrm{A}$ & N/A & $\mathrm{N} / \mathrm{A}$ & N/A & N/A & N/A & $\mathrm{N} / \mathrm{A}$ & $\mathrm{N} / \mathrm{A}$ & N/A \\
\hline Wollastonite & 0.2 & N/A & 47.5 & N/A & N/A & 0.4 & N/A & N/A & 0. & 0.1 & N/A & $\mathrm{N} / \mathrm{A}$ & N/A & N/A & 51 & N/A & N/A & $\mathrm{N} / \mathrm{A}$ & N/A & N/A \\
\hline $\mathrm{Fe}_{2} \mathrm{O}_{3}$ & 1.5 & N/A & N/A & $\mathrm{N} / \mathrm{A}$ & N/A & 97 & N/A & N/A & 0.1 & N/A & N/A & N/A & $\mathrm{N} / \mathrm{A}$ & 0.12 & 1.35 & N/A & N/A & N/A & $\mathrm{N} / \mathrm{A}$ & N/A \\
\hline $\mathrm{Li}_{2} \mathrm{CO}_{3}$ & N/A & N/A & N/A & 59.2 & N/A & N/A & N/A & 40.2 & N/A & N/A & N/A & N/A & $\mathrm{N} / \mathrm{A}$ & $\mathrm{N} / \mathrm{A}$ & N/A & N/A & N/A & N/A & $\mathrm{N} / \mathrm{A}$ & N/A \\
\hline Olivine $-\mathrm{Mg}$ & 0.19 & N/A & N/A & N/A & 0.13 & 7.68 & N/A & A & 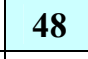 & J/A & N/A & $10 / 1$ & 0.37 & N/A & 42.5 & N/A & N/A & N/A & N/A & N/A \\
\hline $\mathrm{SiO}_{2}$ & 0.14 & N/A & N/A & N/A & N/A & N/A & N/A & N/A & N/A & N/A & N/A & N/A & N/A & N/A & 99.7 & N/A & N/A & $\mathrm{N} / \mathrm{A}$ & N/A & N/A \\
\hline Rutile $\mathrm{TiO}_{2} /$ & 0.5 & N/A & N/A & N/A & 0.16 & 0.7 & N/A & N/A & N/A & N/A & N/A & 0.4 & N/A & N/A & 2.2 & 93.2 & N/A & \begin{tabular}{|l|}
0.45 \\
\end{tabular} & $\mathrm{~N} / \mathrm{A}$ & 1.9 \\
\hline $\mathrm{ZnO}$ & N/A & N/A & N/A & N/A & N/A & N/A & N/A & N/A & N/A & N/A & N/A & N/A & N/A & N/A & N/A & N/A & N/A & $\mathrm{N} / \mathrm{A}$ & 99.8 & N/A \\
\hline $\mathrm{ZrSiO}_{4}$ & 0.25 & N/A & N/A & N/A & N/A & N/A & N/A & N/A & N/A & N/A & N/A & N/A & N/A & N/A & 32.3 & 0.11 & 0.05 & N/A & N/A & 65.5 \\
\hline
\end{tabular}


This page intentionally left blank. 


\section{APPENDIX C.}

TABLE 12, SHEETS \#1, \#2, \#3 AND \# 5 


\begin{tabular}{|c|c|c|c|c|c|}
\hline \multicolumn{6}{|c|}{ Table 12 - Sheet \#1 - Waste Composition Of Each Sample } \\
\hline \multicolumn{2}{|c|}{ Sample Identification } & $\begin{array}{c}\text { LAW } \\
\text { AZ-102 } \\
1.0 \mathrm{M} \mathrm{Na} \\
\text { Pretreated } \\
\text { Feed }\end{array}$ & $\begin{array}{c}\text { LAW } \\
\text { AZ-102 } \\
1.3 \mathrm{M} \mathrm{Na} \\
\text { Pretreated } \\
\text { Feed }\end{array}$ & $\begin{array}{c}\text { LAW } \\
\text { AZ-102 } \\
1.0 \mathrm{M} \mathrm{Na} \\
\text { Melter Feed }\end{array}$ & $\begin{array}{c}\text { LAW } \\
\text { AZ-102 } \\
1.3 \mathrm{M} \mathrm{Na} \\
\text { Melter Feed }\end{array}$ \\
\hline \multicolumn{2}{|c|}{ Sample History } & $\begin{array}{c}\text { Diluted from } \\
\text { original } \\
\text { AZ-102 } \\
4.38 \mathrm{M} \mathrm{Na} \\
\text { Pretreated } \\
\text { Feed } \\
\end{array}$ & $\begin{array}{c}\text { Diluted from } \\
\text { original } \\
\text { AZ-102 } \\
4.38 \mathrm{M} \mathrm{Na} \\
\text { Pretreated } \\
\text { Feed } \\
\end{array}$ & $\begin{array}{c}\text { Glass Former } \\
\text { Chemicals } \\
\text { Added to } \\
1.0 \mathrm{M} \mathrm{Na} \\
\text { Pretreated } \\
\text { Feed } \\
\end{array}$ & $\begin{array}{c}\text { Glass Former } \\
\text { Chemicals } \\
\text { Added to } \\
1.3 \mathrm{M} \mathrm{Na} \\
\text { Pretreated } \\
\text { Feed } \\
\end{array}$ \\
\hline \multicolumn{2}{|c|}{ Sodium Molarity } & 1.02 & 1.33 & 1.29 & 1.54 \\
\hline \multicolumn{2}{|c|}{ Oxide Loading of HLW sludge or Pretreated Sludge } & N/A & N/A & N/A & N/A \\
\hline \multicolumn{2}{|c|}{$\mathrm{pH}$ of the Waste } & 12.01 & 12.15 & 9.04 & 8.72 \\
\hline \multicolumn{6}{|c|}{$<$ MRQ $=$ Below Minimum Reportable Quantity or not measured } \\
\hline \multicolumn{2}{|l|}{ Analyte: } & & & & \\
\hline \multicolumn{2}{|l|}{ Cations } & & & & \\
\hline $\mathrm{Ag}$ & $\mathrm{mg} / \mathrm{L}$ & $<$ MRQ & $<$ MRQ & $<$ MRQ & $<\mathrm{MRQ}$ \\
\hline $\mathrm{Al}$ & $\mathrm{mg} / \mathrm{L}$ & 214 & 289 & 12931 & 15465 \\
\hline As & $\mathrm{mg} / \mathrm{L}$ & $<$ MRQ & $<$ MRQ & $<$ MRQ & $<$ MRQ \\
\hline B & $\mathrm{mg} / \mathrm{L}$ & $<$ MRQ & $<$ MRQ & 23596 & 28194 \\
\hline $\mathrm{Ba}$ & $\mathrm{mg} / \mathrm{L}$ & $<$ MRQ & $<$ MRQ & $<$ MRQ & $<\mathrm{MRQ}$ \\
\hline $\mathrm{Be}$ & $\mathrm{mg} / \mathrm{L}$ & $<$ MRQ & $<$ MRQ & $<$ MRQ & $<\mathrm{MRQ}$ \\
\hline $\mathrm{Bi}$ & $\mathrm{mg} / \mathrm{L}$ & $<$ MRQ & $<$ MRQ & $<$ MRQ & $<\mathrm{MRQ}$ \\
\hline $\mathrm{Ca}$ & $\mathrm{mg} / \mathrm{L}$ & 17.9 & 24.3 & 36434 & 43538 \\
\hline $\mathrm{Cd}$ & $\mathrm{mg} / \mathrm{L}$ & $<$ MRQ & $<$ MRQ & $<$ MRQ & $<\mathrm{MRQ}$ \\
\hline $\mathrm{Ce}$ & $\mathrm{mg} / \mathrm{L}$ & $<$ MRQ & $<$ MRQ & $<$ MRQ & $<$ MRQ \\
\hline $\mathrm{Co}$ & $\mathrm{mg} / \mathrm{L}$ & $<\mathrm{MRQ}$ & $<$ MRQ & $<$ MRQ & $<$ MRQ \\
\hline $\mathrm{Cr}$ & $\mathrm{mg} / \mathrm{L}$ & 273 & 370 & 236 & 290 \\
\hline Cs & $\mathrm{mg} / \mathrm{L}$ & $<$ MRQ & $<$ MRQ & $<$ MRQ & $<\mathrm{MRQ}$ \\
\hline $\mathrm{Cu}$ & $\mathrm{mg} / \mathrm{L}$ & $<$ MRQ & $<$ MRQ & $<$ MRQ & $<\mathrm{MRQ}$ \\
\hline Dy & $\mathrm{mg} / \mathrm{L}$ & $<$ MRQ & $<$ MRQ & $<$ MRQ & $<$ MRQ \\
\hline $\mathrm{Eu}$ & $\mathrm{mg} / \mathrm{L}$ & $<$ MRQ & $<$ MRQ & $<$ MRQ & $<\mathrm{MRQ}$ \\
\hline $\mathrm{Fe}$ & $\mathrm{mg} / \mathrm{L}$ & $<$ MRQ & $<$ MRQ & 27877 & 33317 \\
\hline $\mathrm{Hg}$ & $\mathrm{mg} / \mathrm{L}$ & $<$ MRQ & $<$ MRQ & $<\mathrm{MRQ}$ & $<\mathrm{MRQ}$ \\
\hline $\mathrm{K}$ & $\mathrm{mg} / \mathrm{L}$ & 1220 & 1653 & 816 & 1010 \\
\hline $\mathrm{La}$ & $\mathrm{mg} / \mathrm{L}$ & $<$ MRQ & $<$ MRQ & $<$ MRQ & $<$ MRQ \\
\hline $\mathrm{Li}$ & $\mathrm{mg} / \mathrm{L}$ & $<$ MRQ & $<$ MRQ & 5773 & 6896 \\
\hline $\mathrm{Mg}$ & $\mathrm{mg} / \mathrm{L}$ & 0.8 & 1.1 & 13672 & 16336 \\
\hline $\mathrm{Mn}$ & $\mathrm{mg} / \mathrm{L}$ & $<$ MRQ & $<$ MRQ & 107 & 129 \\
\hline Mo & $\mathrm{mg} / \mathrm{L}$ & 21 & 29 & 14 & 18 \\
\hline $\mathrm{Na}$ & $\mathrm{mg} / \mathrm{L}$ & 23450 & 30576 & 29572 & 35308 \\
\hline $\mathrm{Nb}$ & $\mathrm{mg} / \mathrm{L}$ & $<$ MRQ & $<$ MRQ & 16 & 19 \\
\hline
\end{tabular}




\begin{tabular}{|c|c|c|c|c|c|}
\hline \multicolumn{6}{|c|}{ Table 12 - Sheet \#1 - Waste Composition Of Each Sample } \\
\hline Sample Identification & & $\begin{array}{c}\text { LAW } \\
\text { AZ-102 } \\
1.0 \mathrm{M} \mathrm{Na} \\
\text { Pretreated } \\
\text { Feed }\end{array}$ & $\begin{array}{c}\text { LAW } \\
\text { AZ-102 } \\
1.3 \mathrm{M} \mathrm{Na} \\
\text { Pretreated } \\
\text { Feed }\end{array}$ & $\begin{array}{c}\text { LAW } \\
\text { AZ-102 } \\
1.0 \mathrm{M} \mathrm{Na} \\
\text { Melter Feed }\end{array}$ & $\begin{array}{c}\text { LAW } \\
\text { AZ-102 } \\
1.3 \mathrm{M} \mathrm{Na} \\
\text { Melter Feed }\end{array}$ \\
\hline Analyte: & \multirow{2}{*}{ Units } & & & & \\
\hline Cations & & & & & \\
\hline $\mathrm{Nd}$ & $\mathrm{mg} / \mathrm{L}$ & $<$ MRQ & $<$ MRQ & $<$ MRQ & $<$ MRQ \\
\hline $\mathrm{Ni}$ & $\mathrm{mg} / \mathrm{L}$ & $<$ MRQ & $<$ MRQ & 136 & 162 \\
\hline $\mathrm{P}$ & $\mathrm{mg} / \mathrm{L}$ & 62 & 83 & 83 & 101 \\
\hline $\mathrm{Pb}$ & $\mathrm{mg} / \mathrm{L}$ & 6.9 & 9.3 & 5 & 6 \\
\hline $\mathrm{Pd}$ & $\mathrm{mg} / \mathrm{L}$ & $<$ MRQ & $<\mathrm{MRQ}$ & $<\mathrm{MRQ}$ & $<\mathrm{MRQ}$ \\
\hline $\operatorname{Pr}$ & $\mathrm{mg} / \mathrm{L}$ & $<$ MRQ & $<$ MRQ & $<$ MRQ & $<$ MRQ \\
\hline $\mathrm{Pt}$ & $\mathrm{mg} / \mathrm{L}$ & $<$ MRQ & $<\mathrm{MRQ}$ & $<$ MRQ & $<$ MRQ \\
\hline $\mathrm{Rb}$ & $\mathrm{mg} / \mathrm{L}$ & $<\mathrm{MRQ}$ & $<\mathrm{MRQ}$ & $<\mathrm{MRQ}$ & $<\mathrm{MRQ}$ \\
\hline $\mathrm{Rh}$ & $\mathrm{mg} / \mathrm{L}$ & $<$ MRQ & $<$ MRQ & $<$ MRQ & $<$ MRQ \\
\hline $\mathrm{Ru}$ & $\mathrm{mg} / \mathrm{L}$ & $<\mathrm{MRQ}$ & $<\mathrm{MRQ}$ & $<$ MRQ & $<\mathrm{MRQ}$ \\
\hline $\mathrm{S}$ & $\mathrm{mg} / \mathrm{L}$ & $<$ MRQ & $<\mathrm{MRQ}$ & $<\mathrm{MRQ}$ & $<\mathrm{MRQ}$ \\
\hline $\mathrm{Sb}$ & $\mathrm{mg} / \mathrm{L}$ & $<$ MRQ & $<\mathrm{MRQ}$ & $<$ MRQ & $<\mathrm{MRQ}$ \\
\hline $\mathrm{Se}$ & $\mathrm{mg} / \mathrm{L}$ & $<\mathrm{MRQ}$ & $<$ MRQ & $<$ MRQ & $<\mathrm{MRQ}$ \\
\hline $\mathrm{Si}$ & $\mathrm{mg} / \mathrm{L}$ & 15.0 & 20.4 & 171015 & 204310 \\
\hline $\mathrm{Sn}$ & $\mathrm{mg} / \mathrm{L}$ & 4.6 & 6.2 & 3 & 4 \\
\hline $\mathrm{Sr}$ & $\mathrm{mg} / \mathrm{L}$ & $<$ MRQ & $<\mathrm{MRQ}$ & $<$ MRQ & $<\mathrm{MRQ}$ \\
\hline $\mathrm{Ta}$ & $\mathrm{mg} / \mathrm{L}$ & $<\mathrm{MRQ}$ & $<\mathrm{MRQ}$ & $<\mathrm{MRQ}$ & $<\mathrm{MRQ}$ \\
\hline $\mathrm{Te}$ & $\mathrm{mg} / \mathrm{L}$ & $<\mathrm{MRQ}$ & $<$ MRQ & $<$ MRQ & $<\mathrm{MRQ}$ \\
\hline $\mathrm{Th}$ & $\mathrm{mg} / \mathrm{L}$ & $<\mathrm{MRQ}$ & $<\mathrm{MRQ}$ & $<\mathrm{MRQ}$ & $<\mathrm{MRQ}$ \\
\hline $\mathrm{Ti}$ & $\mathrm{mg} / \mathrm{L}$ & $<\mathrm{MRQ}$ & $<\mathrm{MRQ}$ & 6789 & 8116 \\
\hline $\mathrm{Tl}$ & $\mathrm{mg} / \mathrm{L}$ & $<$ MRQ & $<\mathrm{MRQ}$ & $<\mathrm{MRQ}$ & $<\mathrm{MRQ}$ \\
\hline $\mathrm{U}$ & $\mathrm{mg} / \mathrm{L}$ & $<$ MRQ & $<\mathrm{MRQ}$ & $<$ MRQ & $<\mathrm{MRQ}$ \\
\hline $\mathrm{V}$ & $\mathrm{mg} / \mathrm{L}$ & $<\mathrm{MRQ}$ & $<\mathrm{MRQ}$ & 28 & 34 \\
\hline $\mathrm{W}$ & $\mathrm{mg} / \mathrm{L}$ & $<\mathrm{MRQ}$ & $<\mathrm{MRQ}$ & $<\mathrm{MRQ}$ & $<\mathrm{MRQ}$ \\
\hline $\mathrm{Y}$ & $\mathrm{mg} / \mathrm{L}$ & $<\mathrm{MRQ}$ & $<\mathrm{MRQ}$ & $<$ MRQ & $<\mathrm{MRQ}$ \\
\hline $\mathrm{Zn}$ & $\mathrm{mg} / \mathrm{L}$ & $<$ MRQ & $<\mathrm{MRQ}$ & 29123 & 34809 \\
\hline $\mathrm{Zr}$ & $\mathrm{mg} / \mathrm{L}$ & $<$ MRQ & $<\mathrm{MRQ}$ & 17750 & 17750 \\
\hline \multicolumn{6}{|l|}{ Carbon Analyses } \\
\hline TIC & $\mathrm{mg} / \mathrm{L}$ & 2516 & 3409 & 1683 & 2084 \\
\hline TOC & $\mathrm{mg} / \mathrm{L}$ & 5333 & 7225 & 3566 & 4417 \\
\hline \multicolumn{6}{|l|}{ Anions } \\
\hline $\mathrm{F}$ & $\mathrm{mg} / \mathrm{L}$ & 367 & 497 & 245 & 304 \\
\hline $\mathrm{Cl}$ & $\mathrm{mg} / \mathrm{L}$ & $<$ MRQ & $<$ MRQ & $<$ MRQ & $<$ MRQ \\
\hline $\mathrm{Br}$ & $\mathrm{mg} / \mathrm{L}$ & $<\mathrm{MRQ}$ & $<\mathrm{MRQ}$ & $<$ MRQ & $<\mathrm{MRQ}$ \\
\hline $\mathrm{NO}_{2}$ & $\mathrm{mg} / \mathrm{L}$ & 13239 & 17937 & 8854 & 10965 \\
\hline
\end{tabular}


SRT-RPP-2003-00185, REVISION 0

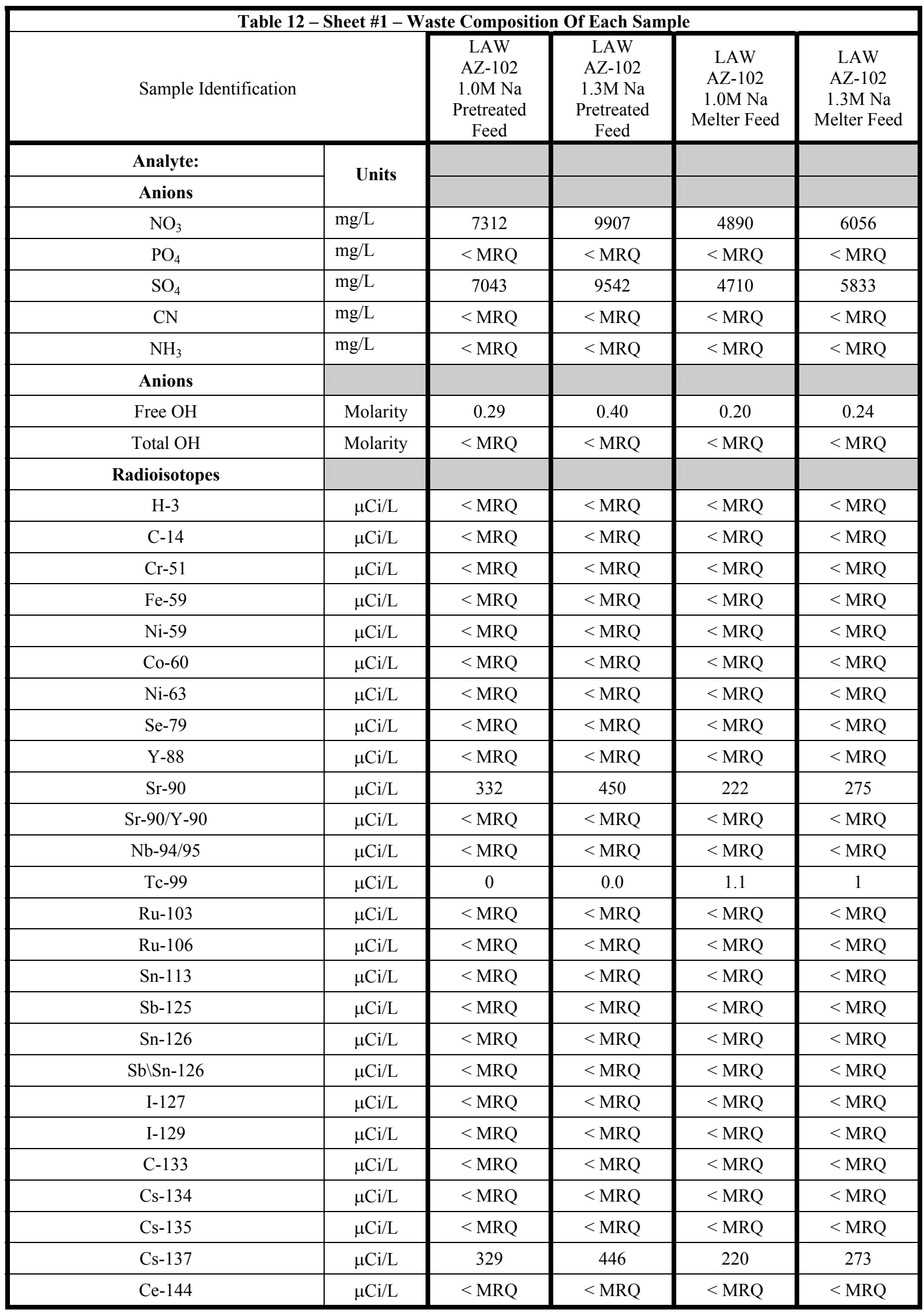




\begin{tabular}{|c|c|c|c|c|c|}
\hline \multicolumn{6}{|c|}{ Table 12 - Sheet \#1 - Waste Composition Of Each Sample } \\
\hline Sample Identification & & $\begin{array}{c}\text { LAW } \\
\text { AZ-102 } \\
1.0 \mathrm{M} \mathrm{Na} \\
\text { Pretreated } \\
\text { Feed }\end{array}$ & $\begin{array}{c}\text { LAW } \\
\text { AZ-102 } \\
1.3 \mathrm{M} \mathrm{Na} \\
\text { Pretreated } \\
\text { Feed }\end{array}$ & $\begin{array}{c}\text { LAW } \\
\text { AZ-102 } \\
1.0 \mathrm{M} \mathrm{Na} \\
\text { Melter Feed }\end{array}$ & $\begin{array}{c}\text { LAW } \\
\text { AZ-102 } \\
1.3 \mathrm{M} \mathrm{Na} \\
\text { Melter Feed }\end{array}$ \\
\hline Analyte: & \multirow{2}{*}{ Units } & & & & \\
\hline Radioisotopes & & & & & \\
\hline Sm-151 & $\mu \mathrm{Ci} / \mathrm{L}$ & $<$ MRQ & $<$ MRQ & $<$ MRQ & $<$ MRQ \\
\hline Eu-152 & $\mu \mathrm{Ci} / \mathrm{L}$ & $<\mathrm{MRQ}$ & $<$ MRQ & $<$ MRQ & $<$ MRQ \\
\hline Eu-154 & $\mu \mathrm{Ci} / \mathrm{L}$ & $<$ MRQ & $<$ MRQ & $<$ MRQ & $<$ MRQ \\
\hline Eu-155 & $\mu \mathrm{Ci} / \mathrm{L}$ & $<$ MRQ & $<$ MRQ & $<$ MRQ & $<$ MRQ \\
\hline $\mathrm{Pa}-231$ & $\mu \mathrm{Ci} / \mathrm{L}$ & $<$ MRQ & $<$ MRQ & $<$ MRQ & $<$ MRQ \\
\hline U-233 & $\mu \mathrm{Ci} / \mathrm{L}$ & $<$ MRQ & $<$ MRQ & $<$ MRQ & $<\mathrm{MRQ}$ \\
\hline $\mathrm{U}-234$ & $\mu \mathrm{Ci} / \mathrm{L}$ & $<\mathrm{MRQ}$ & $<$ MRQ & $<$ MRQ & $<$ MRQ \\
\hline U-235 & $\mu \mathrm{Ci} / \mathrm{L}$ & $<\mathrm{MRQ}$ & $<$ MRQ & $<$ MRQ & $<$ MRQ \\
\hline U-236 & $\mu \mathrm{Ci} / \mathrm{L}$ & $<$ MRQ & $<$ MRQ & $<$ MRQ & $<$ MRQ \\
\hline $\mathrm{U}-238$ & $\mu \mathrm{Ci} / \mathrm{L}$ & $<\mathrm{MRQ}$ & $<$ MRQ & $<$ MRQ & $<\mathrm{MRQ}$ \\
\hline Np-237 & $\mu \mathrm{Ci} / \mathrm{L}$ & $<$ MRQ & $<\mathrm{MRQ}$ & $<$ MRQ & $<$ MRQ \\
\hline $\mathrm{Pu}-236$ & $\mu \mathrm{Ci} / \mathrm{L}$ & $<$ MRQ & $<$ MRQ & $<$ MRQ & $<$ MRQ \\
\hline $\mathrm{Pu}-238$ & $\mu \mathrm{Ci} / \mathrm{L}$ & $<\mathrm{MRQ}$ & $<$ MRQ & $<$ MRQ & $<$ MRQ \\
\hline Pu-239 & $\mu \mathrm{Ci} / \mathrm{L}$ & $<$ MRQ & $<$ MRQ & $<$ MRQ & $<$ MRQ \\
\hline $\mathrm{Pu}-240$ & $\mu \mathrm{Ci} / \mathrm{L}$ & $<$ MRQ & $<$ MRQ & $<$ MRQ & $<$ MRQ \\
\hline $\mathrm{Pu}-239 / 240$ & $\mu \mathrm{Ci} / \mathrm{L}$ & $<$ MRQ & $<\mathrm{MRQ}$ & $<$ MRQ & $<\mathrm{MRQ}$ \\
\hline $\mathrm{Pu}-241$ & $\mu \mathrm{Ci} / \mathrm{L}$ & $<\mathrm{MRQ}$ & $<\mathrm{MRQ}$ & $<$ MRQ & $<$ MRQ \\
\hline $\mathrm{Pu}-242$ & $\mu \mathrm{Ci} / \mathrm{L}$ & $<$ MRQ & $<$ MRQ & $<$ MRQ & $<$ MRQ \\
\hline $\mathrm{Pu}-241 / \mathrm{Am}-241$ & $\mu \mathrm{Ci} / \mathrm{L}$ & $<$ MRQ & $<$ MRQ & $<$ MRQ & $<$ MRQ \\
\hline Am-241 & $\mu \mathrm{Ci} / \mathrm{L}$ & $<$ MRQ & $<$ MRQ & $<$ MRQ & $<$ MRQ \\
\hline Am-241, Am-243 & $\mu \mathrm{Ci} / \mathrm{L}$ & $<\mathrm{MRQ}$ & $<\mathrm{MRQ}$ & $<\mathrm{MRQ}$ & $<$ MRQ \\
\hline Am-242 & $\mu \mathrm{Ci} / \mathrm{L}$ & $<\mathrm{MRQ}$ & $<\mathrm{MRQ}$ & $<$ MRQ & $<$ MRQ \\
\hline Am-243 & $\mu \mathrm{Ci} / \mathrm{L}$ & $<$ MRQ & $<\mathrm{MRQ}$ & $<\mathrm{MRQ}$ & $<\mathrm{MRQ}$ \\
\hline $\mathrm{Cm}-242$ & $\mu \mathrm{Ci} / \mathrm{L}$ & $<$ MRQ & $<$ MRQ & $<$ MRQ & $<$ MRQ \\
\hline $\mathrm{Cm}-243$ & $\mu \mathrm{Ci} / \mathrm{L}$ & $<\mathrm{MRQ}$ & $<$ MRQ & $<$ MRQ & $<\mathrm{MRQ}$ \\
\hline $\mathrm{Cm}-244$ & $\mu \mathrm{Ci} / \mathrm{L}$ & $<\mathrm{MRQ}$ & $<\mathrm{MRQ}$ & $<\mathrm{MRQ}$ & $<\mathrm{MRQ}$ \\
\hline $\mathrm{Cm}-243 / 244$ & $\mu \mathrm{Ci} / \mathrm{L}$ & $<$ MRQ & $<\mathrm{MRQ}$ & $<$ MRQ & $<\mathrm{MRQ}$ \\
\hline $\begin{array}{c}\text { Sum of alpha }(\mathrm{TRU})=\mathrm{S}(\mathrm{Pu}-238, \mathrm{Pu}- \\
239, \mathrm{Pu}-240, \mathrm{Am}-241)\end{array}$ & $\mu \mathrm{Ci} / \mathrm{L}$ & $<$ MRQ & $<$ MRQ & $<$ MRQ & $<$ MRQ \\
\hline Total alpha & $\mu \mathrm{Ci} / \mathrm{L}$ & $<$ MRQ & $<$ MRQ & $<$ MRQ & $<$ MRQ \\
\hline Total beta & $\mu \mathrm{Ci} / \mathrm{L}$ & $<\mathrm{MRQ}$ & $<\mathrm{MRQ}$ & $<$ MRQ & $<\mathrm{MRQ}$ \\
\hline Total gamma & $\mu \mathrm{Ci} / \mathrm{L}$ & $<\mathrm{MRQ}$ & $<\mathrm{MRQ}$ & $<$ MRQ & $<$ MRQ \\
\hline \multicolumn{6}{|l|}{ Radioisotopes } \\
\hline 235 & $\mu \mathrm{g} / \mathrm{L}$ & 9.3 & 12.7 & 35.8 & 44.3 \\
\hline 237 & $\mu \mathrm{g} / \mathrm{L}$ & 53.5 & 72.5 & 685.0 & 848.3 \\
\hline
\end{tabular}




\begin{tabular}{|c|c|c|c|c|c|}
\hline \multicolumn{6}{|c|}{ Table 12 - Sheet \#1 - Waste Composition Of Each Sample } \\
\hline \multicolumn{2}{|l|}{ Sample Identification } & $\begin{array}{c}\text { LAW } \\
\mathrm{AZ}-102 \\
1.0 \mathrm{M} \mathrm{Na}\end{array}$ & $\begin{array}{c}\text { LAW } \\
\mathrm{AZ}-102 \\
1.3 \mathrm{M} \mathrm{Na}\end{array}$ & $\begin{array}{l}\text { LAW } \\
\text { AZ-102 }\end{array}$ & $\begin{array}{l}\text { LAW } \\
\text { AZ-102 }\end{array}$ \\
\hline Analyte: & \multirow{2}{*}{ Units } & & & & \\
\hline Radioisotopes & & & & & \\
\hline 238 & $\mu \mathrm{g} / \mathrm{L}$ & 1024.3 & 1387.8 & 6.3 & 7.7 \\
\hline 239 & $\mu \mathrm{g} / \mathrm{L}$ & 20.1 & 27.3 & 13.5 & 16.7 \\
\hline \multicolumn{6}{|l|}{ Organic analytes: } \\
\hline Oxalate & $\mathrm{mg} / \mathrm{L}$ & 1238 & 1678 & 828 & 1026 \\
\hline Citrate & $\mathrm{mg} / \mathrm{L}$ & $<$ MRQ & $<$ MRQ & $<$ MRQ & $<$ MRQ \\
\hline Formate & $\mathrm{mg} / \mathrm{L}$ & $<$ MRQ & $<$ MRQ & $<$ MRQ & $<$ MRQ \\
\hline Gluconate & $\mathrm{mg} / \mathrm{L}$ & $<$ MRQ & $<$ MRQ & $<$ MRQ & $<$ MRQ \\
\hline Glycolate & $\mathrm{mg} / \mathrm{L}$ & $<$ MRQ & $<$ MRQ & $<$ MRQ & $<$ MRQ \\
\hline $\begin{array}{l}\text { EDTA (ethylenediaminetetraacetic } \\
\text { acid) }\end{array}$ & $\mathrm{mg} / \mathrm{L}$ & $<$ MRQ & $<$ MRQ & $<$ MRQ & $<$ MRQ \\
\hline $\begin{array}{c}\text { HEDTA (N-(2- } \\
\text { hydroxyethyl)ethylenediaminetriacetic } \\
\text { acid) }\end{array}$ & $\mathrm{mg} / \mathrm{L}$ & $<$ MRQ & $<$ MRQ & $<$ MRQ & $<$ MRQ \\
\hline D2EHPA (bis-(2-ethylhexyl)phosphate & $\mathrm{mg} / \mathrm{L}$ & $<$ MRQ & $<$ MRQ & $<$ MRQ & $<\mathrm{MRQ}$ \\
\hline NTA (nitrilotriacetic acid) & $\mathrm{mg} / \mathrm{L}$ & $<$ MRQ & $<$ MRQ & $<$ MRQ & $<$ MRQ \\
\hline IDA (iminodiacetic acid) & $\mathrm{mg} / \mathrm{L}$ & $<$ MRQ & $<\mathrm{MRQ}$ & $<$ MRQ & $<$ MRQ \\
\hline Succinic Acid & $\mathrm{mg} / \mathrm{L}$ & $<$ MRQ & $<$ MRQ & $<$ MRQ & $<$ MRQ \\
\hline ED3A (ethylenediaminetriacetic acid) & $\mathrm{mg} / \mathrm{L}$ & $<$ MRQ & $<$ MRQ & $<\mathrm{MRQ}$ & $<$ MRQ \\
\hline \multicolumn{6}{|l|}{$\begin{array}{l}\text { Analytes Obtained on an } \\
\text { Opportunistic Basis: }\end{array}$} \\
\hline $\mathrm{CO}_{3}$ & Molarity & 0.13 & 0.18 & 0.09 & 0.11 \\
\hline $\mathrm{CO}_{2}$ & $\mathrm{mg} / \mathrm{L}$ & $<$ MRQ & $<$ MRQ & 60992 & 72887 \\
\hline $\mathrm{U}+\mathrm{Th}$ & $\mathrm{mg} / \mathrm{L}$ & $<$ MRQ & $<$ MRQ & 16.3 & 19.5 \\
\hline
\end{tabular}




\begin{tabular}{|c|c|c|c|c|c|c|}
\hline \multicolumn{3}{|c|}{ Pretreated Waste or HLW Pretreated Sludge Identification } & \multicolumn{2}{|c|}{$\begin{array}{c}\text { LAW AZ-102 } 1.0 \mathrm{M} \mathrm{Na} \\
\text { Melter Feed }\end{array}$} & \multicolumn{2}{|c|}{$\begin{array}{c}\text { LAW AZ-102 } 1.3 \mathrm{M} \mathrm{Na} \\
\text { Melter Feed }\end{array}$} \\
\hline \multicolumn{3}{|c|}{$\begin{array}{l}\text { Pretreatment History (include washing, leaching, chemical } \\
\text { precipitation, mechanical agitation of any kind (time and } \\
\text { intensity) }\end{array}$} & \multicolumn{2}{|c|}{$\begin{array}{l}\text { See WSRC-TR-2001- } \\
00395\end{array}$} & \multicolumn{2}{|c|}{$\begin{array}{c}\text { See WSRC-TR-2001- } \\
00395\end{array}$} \\
\hline \multicolumn{2}{|c|}{$\begin{array}{c}\text { Sodium Concentration of LAW Pretreated } \\
\text { Waste }\end{array}$} & $\begin{array}{l}\mathrm{Na} \\
\text { Molarity: }\end{array}$ & \multicolumn{2}{|c|}{1.02} & \multicolumn{2}{|c|}{1.33} \\
\hline \multicolumn{2}{|c|}{ Oxide Loading of HLW Pretreated Sludge } & $\begin{array}{l}\text { Total } \\
\text { Grams } \\
\text { Oxide Per } \\
\text { Liter: }\end{array}$ & \multicolumn{2}{|c|}{ N/A } & \multicolumn{2}{|c|}{ N/A } \\
\hline Source Chemical & Manufacturer & Oxide & $\begin{array}{c}\text { Target } \\
\text { Mass }(\mathrm{g})\end{array}$ & $\begin{array}{c}\text { Actual } \\
\text { Mass } \\
\text { Added }(\mathrm{g})\end{array}$ & $\begin{array}{c}\text { Target } \\
\text { Mass }(\mathrm{g})\end{array}$ & $\begin{array}{c}\text { Actual } \\
\text { Mass } \\
\text { Added }(g)\end{array}$ \\
\hline Kyanite & Kyanite Mining Corp & $\mathrm{Al}_{2} \mathrm{O}_{3}$ & 22.10 & 22.102 & 12.95 & 12.953 \\
\hline Boric Acid Technical & U.S. Borax & $\mathrm{B}_{2} \mathrm{O}_{3}$ & 37.08 & 37.083 & 21.72 & 21.720 \\
\hline 10M Borax & U.S. Borax & $\mathrm{Na}_{2} \mathrm{O} / \mathrm{B}_{2} \mathrm{O}_{3}$ & N.A & N/A & N.A & N/A \\
\hline Soda Ash & Solvay Minerals & $\mathrm{Na}_{2} \mathrm{CO}_{3}$ & 8.85 & 8.85 & 5.19 & 5.190 \\
\hline Wollastonite & NYCO & $\mathrm{CaO}$ & 29.60 & 29.602 & 17.34 & 17.340 \\
\hline $\mathrm{Fe}_{2} \mathrm{O}_{3} 5001$ & Prince Mfg. Co. & $\mathrm{Fe}_{2} \mathrm{O}_{3}$ & 10.09 & 10.091 & 5.91 & 5.912 \\
\hline $\mathrm{Li}_{2} \mathrm{CO}_{3}$ & Chemettal-Foote & $\mathrm{Li}_{2} \mathrm{O}$ & 22.23 & 22.233 & 13.02 & 13.020 \\
\hline Olivine & Unimin Corp & $\mathrm{MgO}$ & 12.89 & 12.89 & 7.55 & 7.550 \\
\hline SCS-75 & U.S. Silica & $\mathrm{SiO}_{2}$ & 68.13 & 68.181 & 39.92 & 39.920 \\
\hline Rutile (Air floated) & Chemalloy Co. & $\mathrm{TiO}_{2}$ & 3.085 & 3.092 & 1.81 & 1.812 \\
\hline Kadox & Zinc Corp Amer. & $\mathrm{ZnO}$ & 10.02 & 10.022 & 5.87 & 5.872 \\
\hline Zircon & Amer. Miner, Inc. & $\mathrm{ZrO}_{2}$ & 10.01 & 10.01 & 5.87 & 5.870 \\
\hline Sucrose & Amalgamated Sugar & Sugar & N/A & N/A & N/A & $\mathrm{N} / \mathrm{A}$ \\
\hline
\end{tabular}


Table 12 - Sheet\#2 - LAW Melter Feed Preparation Description Continued

\section{Mixing Operation Data Needed to Compare Mixing of the Melter Feed}

\begin{tabular}{|c|c|c|c|}
\hline Melter Feed ID: & $\begin{array}{c}\text { AZ-1021.0 M LAW } \\
3 \text { days of Mixing }\end{array}$ & $\begin{array}{c}\text { AZ-102 1.0 M LAW } \\
\text { MF } 7 \text { day }\end{array}$ & $\begin{array}{l}\text { AZ-102 1.3 M LAW } \\
\text { Melter Feed + } 24 \text { Hrs }\end{array}$ \\
\hline $\begin{array}{c}\text { Processing Scale } \\
\text { (lab/bench, pilot or full) }\end{array}$ & Lab/Bench & Lab Scale & Lab/Bench \\
\hline \multicolumn{4}{|l|}{ Activity/Property } \\
\hline $\begin{array}{c}\text { Order of Chemical } \\
\text { Additions }\end{array}$ & GFCs are blended & GFCs are blended & GFC are blended \\
\hline Mixing Time & 3 days & $\begin{array}{c}4 \text { days after the initial } 3 \\
\text { days of mixing }\end{array}$ & 24 hours \\
\hline Impeller Speed & 325 RPM & 200 RPM & 600 RPM \\
\hline Impeller Diameter & $50.69 \mathrm{~mm}$ & $50.69 \mathrm{~mm}$ & $38.3 \mathrm{~mm}$ \\
\hline Tank Diameter & $83.4 \mathrm{~mm}$ & $83.4 \mathrm{~mm}$ & $63.25 \mathrm{~mm}$ \\
\hline Number of Baffles & None & None & None \\
\hline Size of Baffles & None & None & None \\
\hline Depth of Impeller & Just of bottom & Just of bottom & Just of bottom \\
\hline Comments & None & None & None \\
\hline
\end{tabular}




\begin{tabular}{|c|c|c|c|c|c|}
\hline \multicolumn{6}{|c|}{ Table 12 - Sheet\#3 - Physical Property Data } \\
\hline Physical Property & $\begin{array}{c}\text { LAW AZ-102 } \\
1.0 \mathrm{M} \mathrm{Na} \\
\text { Pretreated } \\
\text { Feed } \\
\end{array}$ & $\begin{array}{c}\text { LAW AZ-102 } \\
1.3 \mathrm{M} \mathrm{Na} \\
\text { Pretreated } \\
\text { Feed } \\
\end{array}$ & $\begin{array}{l}\text { AZ-102 } 1.0 \mathrm{M} \\
\text { LAW } 3 \text { days of } \\
\text { Mixing }\end{array}$ & $\begin{array}{l}\text { AZ-102 } 1.0 \mathrm{M} \\
\text { LAW } \\
\text { MF } 7 \text { day }\end{array}$ & $\begin{array}{l}\text { AZ-102 1.3 M } \\
\text { LAW Melter } \\
\text { Feed }+24 \text { Hrs }\end{array}$ \\
\hline $\begin{array}{c}\text { Sodium concentration of LAW } \\
\text { waste or pretreated waste } \\
\text { (Molar) }\end{array}$ & 1.02 & 1.33 & 1.02 & 1.02 & 1.32 \\
\hline $\begin{array}{c}\text { Oxide loading of HLW sludge } \\
\text { or pretreated sludge (total } \\
\text { grams oxide/Liter) }\end{array}$ & N/A & N/A & N/A & N/A & N/A \\
\hline $\begin{array}{c}\mathrm{pH}-\text { (aging } 1 \text { day, } 1 \text { week, } 1 \\
\text { mo })\end{array}$ & 12.01 & 12.15 & 9.04 (3 days) & 9.22 (7 days) & 8.72 (1 day) \\
\hline Solid phases present & yes & Yes & Yes & Yes & yes \\
\hline $\begin{array}{l}\text { Particle size distribution - Mean } \\
\text { Vol. Distribution }(\mu \mathrm{m})\end{array}$ & N/A & N/A & 28.86 & 27.32 & 30.53 \\
\hline $\begin{array}{c}\text { Particle size distribution - Mean } \\
\text { No. Distribution }(\mu \mathrm{m})\end{array}$ & N/A & N/A & 0.353 & 0.361 & 0.354 \\
\hline Density - Bulk slurry $(\mathrm{g} / \mathrm{mL})$ & N/A & N/A & 1.55 & 1.53 & 1.67 \\
\hline Density - settled solids $(\mathrm{g} / \mathrm{mL})$ & N/A & $\mathrm{N} / \mathrm{A}$ & 1.76 & 1.75 & 1.82 \\
\hline $\begin{array}{c}\text { Density - centrifuged solids } \\
(\mathrm{g} / \mathrm{mL})\end{array}$ & $\mathrm{N} / \mathrm{A}$ & $\mathrm{N} / \mathrm{A}$ & 1.86 & 1.89 & 1.90 \\
\hline $\begin{array}{l}\text { Density - supernatant liquid } \\
\qquad(\mathrm{g} / \mathrm{mL})\end{array}$ & 1.05 & 1.07 & 1.09 & 1.08 & 1.10 \\
\hline $\begin{array}{c}\text { Vol. \% settled solids after } 72 \\
\text { hours }\end{array}$ & N/A & N/A & 69.37 & 67.39 & 78.65 \\
\hline Vol. \% centrifuged solids & N/A & $\mathrm{N} / \mathrm{A}$ & 61.37 & 59.42 & 72.40 \\
\hline Wt $\%$ total dried solids & 6.34 & 8.14 & 52.15 & 53.41 & 59.61 \\
\hline Wt $\%$ centrifuged solids & N/A & $\mathrm{N} / \mathrm{A}$ & 73.34 & 73.21 & 82.67 \\
\hline Wt $\%$ oven dried solids & $\mathrm{N} / \mathrm{A}$ & N/A & 67.68 & 69.46 & 70.06 \\
\hline Wt \% undissolved solids & N/A & N/A & 47.19 & 48.52 & 55.26 \\
\hline Wt \% dissolved solids & N/A & N/A & 4.96 & 4.89 & 4.35 \\
\hline
\end{tabular}




\begin{tabular}{|c|c|c|c|c|}
\hline $\begin{array}{c}\text { Model/model Parameter } \\
\text { Shear Strength (by Vane Method): }\end{array}$ & \multicolumn{2}{|c|}{$\begin{array}{c}\text { LAW AZ-102 1.0M Na } \\
\text { Pretreated Feed }\end{array}$} & \multicolumn{2}{|c|}{$\begin{array}{c}\text { LAW AZ-102 1.0M Na } \\
\text { Pretreated Feed }\end{array}$} \\
\hline$\tau_{\mathrm{o}, \text { vane }}$ - Shear Strength $(\mathrm{Pa})$ & N/A & N/A & N/A & N/A \\
\hline \multicolumn{5}{|l|}{ Ostwald (or Power Law): } \\
\hline Shear rate range data fitted $\left(\mathrm{sec}^{-1}\right)$ & $0-2000$ & $0-2000$ & $0-2000$ & $0-2000$ \\
\hline $\mathrm{m}-$ consistency coefficient $\left(\mathrm{Pa}-\mathrm{sec}^{\mathrm{n}}\right)$ & 0.0012 & 0.0012 & 0.0010 & 0.0011 \\
\hline $\mathrm{n}$ - power law exponent & 1 (forced) & 1 (forced) & 1 (forced) & 1 (forced) \\
\hline $\mathrm{R}^{2}-$ correlation coefficient & 0.9964 & 0.9972 & 0.9932 & 0.9925 \\
\hline \multicolumn{5}{|l|}{ Bingham Plastic: } \\
\hline Shear rate range data fitted $\left(\mathrm{sec}^{-1}\right)$ & $\mathrm{N} / \mathrm{A}$ & $\mathrm{N} / \mathrm{A}$ & N/A & $\mathrm{N} / \mathrm{A}$ \\
\hline$\tau_{\mathrm{O}}{ }^{\mathrm{B}}$ - Bingham yield stress $(\mathrm{Pa})$ & N/A & N/A & N/A & N/A \\
\hline$\eta_{P}-$ Bingham plastic viscosity $(\mathrm{cP})$ & N/A & N/A & N/A & N/A \\
\hline $\mathrm{R}^{2}-$ correlation coefficient & N/A & N/A & N/A & N/A \\
\hline \multicolumn{5}{|l|}{ Herschel-Bulkley: } \\
\hline Shear rate range data fitted $\left(\mathrm{sec}^{-1}\right)$ & $\mathrm{N} / \mathrm{A}$ & $\mathrm{N} / \mathrm{A}$ & N/A & $\mathrm{N} / \mathrm{A}$ \\
\hline$\tau_{\mathrm{O}}{ }^{\mathrm{H}}$ - Herschel-Bulkley yield stress $(\mathrm{Pa})$ & N/A & N/A & N/A & N/A \\
\hline k - Herschel-Bulkely consistency coefficient (cP) & $\mathrm{N} / \mathrm{A}$ & $\mathrm{N} / \mathrm{A}$ & N/A & $\mathrm{N} / \mathrm{A}$ \\
\hline b - Hershel-Bulkely power law exponent & N/A & N/A & N/A & N/A \\
\hline $\mathrm{R}^{2}-$ correlation coefficient & N/A & $\mathrm{N} / \mathrm{A}$ & N/A & N/A \\
\hline
\end{tabular}




\begin{tabular}{|c|c|c|c|c|c|c|}
\hline $\begin{array}{c}\text { Model/model Parameter } \\
\text { Shear Strength (by Vane Method): }\end{array}$ & \multicolumn{2}{|c|}{$\begin{array}{c}\text { LAW AZ-102 1.0M Na } \\
\text { Melter Feed - } 3 \text { days }\end{array}$} & \multicolumn{2}{|c|}{$\begin{array}{c}\text { LAW AZ-102 1.0M Na } \\
\text { Melter Feed - } 7 \text { days }\end{array}$} & \multicolumn{2}{|c|}{$\begin{array}{l}\text { LAW AZ-102 1.3M Na } \\
\text { Melter Feed - } 1 \text { day }\end{array}$} \\
\hline$\tau_{\text {o,vane }}$ - Shear Strength $(\mathrm{Pa})$ & $218(72 \mathrm{hrs})$ & N/A & $112(48 \mathrm{hrs})^{*}$ & $494(48 \mathrm{hrs})^{*}$ & 2349 (50 hrs) & $\mathrm{N} / \mathrm{A}$ \\
\hline \multicolumn{7}{|l|}{ Ostwald (or Power Law): } \\
\hline Shear rate range data fitted $\left(\mathrm{sec}^{-1}\right)$ & N/A & $\mathrm{N} / \mathrm{A}$ & $\mathrm{N} / \mathrm{A}$ & N/A & N/A & $\mathrm{N} / \mathrm{A}$ \\
\hline $\mathrm{m}-$ consistency coefficient $\left(\mathrm{Pa}-\mathrm{sec}^{\mathrm{n}}\right)$ & N/A & $\mathrm{N} / \mathrm{A}$ & $\mathrm{N} / \mathrm{A}$ & N/A & N/A & $\mathrm{N} / \mathrm{A}$ \\
\hline $\mathrm{n}$ - power law exponent & N/A & N/A & $\mathrm{N} / \mathrm{A}$ & N/A & N/A & N/A \\
\hline $\mathrm{R}^{2}-$ correlation coefficient & N/A & $\mathrm{N} / \mathrm{A}$ & N/A & N/A & N/A & $\mathrm{N} / \mathrm{A}$ \\
\hline \multicolumn{7}{|l|}{ Bingham Plastic: } \\
\hline Shear rate range data fitted $\left(\mathrm{sec}^{-1}\right)$ & N/A & $\mathrm{N} / \mathrm{A}$ & $\mathrm{N} / \mathrm{A}$ & $\mathrm{N} / \mathrm{A}$ & N/A & $\mathrm{N} / \mathrm{A}$ \\
\hline$\tau_{\mathrm{O}}{ }^{\mathrm{B}}-$ Bingham yield stress $(\mathrm{Pa})$ & $\mathrm{N} / \mathrm{A}$ & N/A & $\mathrm{N} / \mathrm{A}$ & $\mathrm{N} / \mathrm{A}$ & $\mathrm{N} / \mathrm{A}$ & $\mathrm{N} / \mathrm{A}$ \\
\hline$\eta_{\mathrm{P}}-$ Bingham plastic viscosity $(\mathrm{cP})$ & N/A & N/A & N/A & N/A & N/A & $\mathrm{N} / \mathrm{A}$ \\
\hline $\mathrm{R}^{2}-$ correlation coefficient & $\mathrm{N} / \mathrm{A}$ & $\mathrm{N} / \mathrm{A}$ & N/A & $\mathrm{N} / \mathrm{A}$ & $\mathrm{N} / \mathrm{A}$ & $\mathrm{N} / \mathrm{A}$ \\
\hline \multicolumn{7}{|l|}{ Herschel-Bulkley: } \\
\hline Shear rate range data fitted $\left(\mathrm{sec}^{-1}\right)$ & N/A & $\mathrm{N} / \mathrm{A}$ & $\mathrm{N} / \mathrm{A}$ & N/A & $\mathrm{N} / \mathrm{A}$ & $\mathrm{N} / \mathrm{A}$ \\
\hline$\tau_{\mathrm{O}}^{\mathrm{H}}$ - Herschel-Bulkley yield stress $(\mathrm{Pa})$ & $\mathrm{N} / \mathrm{A}$ & $\mathrm{N} / \mathrm{A}$ & $\mathrm{N} / \mathrm{A}$ & $\mathrm{N} / \mathrm{A}$ & $\mathrm{N} / \mathrm{A}$ & $\mathrm{N} / \mathrm{A}$ \\
\hline k - Herschel-Bulkely consistency coefficient (cP) & $\mathrm{N} / \mathrm{A}$ & N/A & $\mathrm{N} / \mathrm{A}$ & N/A & N/A & $\mathrm{N} / \mathrm{A}$ \\
\hline b - Hershel-Bulkely power law exponent & N/A & $\mathrm{N} / \mathrm{A}$ & $\mathrm{N} / \mathrm{A}$ & N/A & $\mathrm{N} / \mathrm{A}$ & $\mathrm{N} / \mathrm{A}$ \\
\hline $\mathrm{R}^{2}-$ correlation coefficient & $\mathrm{N} / \mathrm{A}$ & $\mathrm{N} / \mathrm{A}$ & $\mathrm{N} / \mathrm{A}$ & $\mathrm{N} / \mathrm{A}$ & N/A & $\mathrm{N} / \mathrm{A}$ \\
\hline
\end{tabular}

N/A - Flow curves were not fitted to any of the above rheological models due to settling issues related to this specific melter feed.

* Measurement taken in one cup. The $2^{\text {nd }}$ measurement was taken at a deeper depth than the $1^{\text {st }}$ measurement. 


\begin{tabular}{|c|c|c|c|c|c|c|}
\hline \begin{tabular}{|c|} 
Model/model Parameter \\
Shear Strength (by Vane Method):
\end{tabular} & \multicolumn{2}{|c|}{$\begin{array}{l}\text { LAW AZ-102 1.0M Na Melter } \\
\text { Feed Supernatant - } 3 \text { days }\end{array}$} & \multicolumn{2}{|c|}{$\begin{array}{l}\text { LAW AZ-102 1.0M Na Melter } \\
\text { Feed Supernatant }-7 \text { days }\end{array}$} & \multicolumn{2}{|c|}{$\begin{array}{c}\text { LAW AZ-102 1.3M Na Melte } \\
\text { Feed Supernatant - } 1 \text { day }\end{array}$} \\
\hline$\tau_{o, v a n e}-$ Shear Strength $(\mathrm{Pa})$ & $\mathrm{N} / \mathrm{A}$ & $\mathrm{N} / \mathrm{A}$ & $\mathrm{N} / \mathrm{A}$ & N/A & N/A & N/A \\
\hline \multicolumn{7}{|l|}{ Ostwald (or Power Law): } \\
\hline Shear rate range data fitted $\left(\mathrm{sec}^{-1}\right)$ & $0-2000$ & $0-2000$ & $0-2000$ & $0-2000$ & $0-2000$ & $0-2000$ \\
\hline $\mathrm{m}-$ consistency coefficient $\left(\mathrm{Pa}-\mathrm{sec}^{\mathrm{n}}\right)$ & 0.0018 & 0.0018 & 0.0018 & 0.0017 & 0.002 & 0.0019 \\
\hline $\mathrm{n}$-power law exponent & 1 (forced) & 1 (forced) & 1 (forced) & 1 (forced) & 1 (forced) & 1 (forced) \\
\hline $\mathrm{R}^{2}-$ correlation coefficient & 0.9956 & 0.9973 & 0.9981 & 0.9972 & 0.9988 & 0.9987 \\
\hline \multicolumn{7}{|l|}{ Bingham Plastic: } \\
\hline Shear rate range data fitted $\left(\mathrm{sec}^{-1}\right)$ & N/A & $\mathrm{N} / \mathrm{A}$ & $\mathrm{N} / \mathrm{A}$ & $\mathrm{N} / \mathrm{A}$ & N/A & N/A \\
\hline$\tau_{0}{ }^{B}$ - Bingham yield stress $(\mathrm{Pa})$ & N/A & N/A & $\mathrm{N} / \mathrm{A}$ & $\mathrm{N} / \mathrm{A}$ & $\mathrm{N} / \mathrm{A}$ & $\mathrm{N} / \mathrm{A}$ \\
\hline$\eta_{\mathrm{P}}-$ Bingham plastic viscosity (cP) & $\mathrm{N} / \mathrm{A}$ & $\mathrm{N} / \mathrm{A}$ & $\mathrm{N} / \mathrm{A}$ & N/A & $\mathrm{N} / \mathrm{A}$ & $\mathrm{N} / \mathrm{A}$ \\
\hline $\mathrm{R}^{2}-$ correlation coefficient & N/A & N/A & $\mathrm{N} / \mathrm{A}$ & N/A & $\mathrm{N} / \mathrm{A}$ & $\mathrm{N} / \mathrm{A}$ \\
\hline \multicolumn{7}{|l|}{ Herschel-Bulkley: } \\
\hline Shear rate range data fitted $\left(\mathrm{sec}^{-1}\right)$ & N/A & $\mathrm{N} / \mathrm{A}$ & $\mathrm{N} / \mathrm{A}$ & N/A & $\mathrm{N} / \mathrm{A}$ & $\mathrm{N} / \mathrm{A}$ \\
\hline$\tau_{\mathrm{O}}^{\mathrm{H}}-$ Herschel-Bulkley yield stress $(\mathrm{Pa})$ & N/A & N/A & $\mathrm{N} / \mathrm{A}$ & $\mathrm{N} / \mathrm{A}$ & $\mathrm{N} / \mathrm{A}$ & $\mathrm{N} / \mathrm{A}$ \\
\hline k - Herschel-Bulkely consistency coefficient (cP) & N/A & N/A & $\mathrm{N} / \mathrm{A}$ & N/A & $\mathrm{N} / \mathrm{A}$ & $\mathrm{N} / \mathrm{A}$ \\
\hline b- Hershel-Bulkely power law exponent & N/A & $\mathrm{N} / \mathrm{A}$ & $\mathrm{N} / \mathrm{A}$ & N/A & $\mathrm{N} / \mathrm{A}$ & $\mathrm{N} / \mathrm{A}$ \\
\hline $\mathrm{R}^{2}-$ correlation coefficient & $\mathrm{N} / \mathrm{A}$ & $\mathrm{N} / \mathrm{A}$ & $\mathrm{N} / \mathrm{A}$ & $\mathrm{N} / \mathrm{A}$ & $\mathrm{N} / \mathrm{A}$ & $\mathrm{N} / \mathrm{A}$ \\
\hline
\end{tabular}

